Priscila Sobrinho de Oliveira

Trajetórias de encarceramento nas memórias de presos políticos no Brasil das décadas de 1930 e 1940

Dissertação de Mestrado

Dissertação apresentada como requisito parcial para obtenção do grau de Mestre pelo Programa de PósGraduação em História Social da Cultura do Departamento de História do Centro de Ciências Sociais da PUC-Rio.

Orientador: Prof. Diego Antonio Galeano 
Priscila Sobrinho de Oliveira

\title{
Trajetórias de encarceramento nas memórias de presos políticos no Brasil das décadas de 1930 e 1940
}

Dissertação apresentada como requisito parcial para obtenção do grau de Mestre pelo Programa de PósGraduação em História Social da Cultura do Departamento de História do Centro de Ciências Sociais da PUC-Rio. Aprovada pela Comissão Examinadora abaixo assinada.

\author{
Prof. Diego Antonio Galeano \\ Orientador \\ Departamento de História - PUC-Rio
}

Prof. Marcos Luiz Bretas da Fonseca Instituto de História - UFRJ

Prof ${ }^{\mathrm{a}}$ Larissa Rosa Côrrea Departamento de História - PUC-Rio

Prof. Augusto César Pinheiro da Silva Vice-Decano de Pós-Graduação do Centro de Ciências Sociais - PUC-Rio 
Todos os direitos reservados. É proibida a reprodução total ou parcial do trabalho sem a autorização da universidade, da autora e do orientador.

\section{Priscila Sobrinho de Oliveira}

Graduada em História pela Pontifícia Universidade Católica do Rio de Janeiro (PUC-Rio) (2010) e mestre em História Social da Cultura (2018) pela mesma instituição. Tem experiência na área de história do Brasil republicano, com ênfase na história das prisões, crime e polícia.

Ficha Catalográfica

Oliveira, Priscila Sobrinho de

Trajetórias de encarceramento nas memórias de presos políticos no Brasil das décadas de 1930 e 1940 / Priscila Sobrinho de Oliveira ; orientador: Diego Antonio Galeano. - 2018.

$100 \mathrm{f}$. : il. color. ; $30 \mathrm{~cm}$

Dissertação (mestrado)-Pontifícia Universidade Católica do Rio de Janeiro, Departamento de História, 2018.

Inclui bibliografia

1. História - Teses. 2. História Social da Cultura - Teses. 3. Preso político. 4. Preso comum. 5. Memórias prisionais. I. Galeano, Diego. II. Pontifícia Universidade Católica do Rio de Janeiro. Departamento de História. III. Título.

CDD: 900 


\section{Agradecimentos}

Agradeço e dedico este trabalho ao meu pai, pela herança de afeto e inspiração e à minha mãe, por toda a generosidade e exemplo de luta e caráter. Não tenho palavras para definir a gratidão que sinto por terem me ensinado que a vida é feita de infinitas possibilidades e que devemos sempre tentar ser a melhor versão de nós mesmos. Tudo isso é por vocês e para vocês. E sem vocês, eu nada teria feito.

Ao meu tio Evaldo, por sempre ter ocupado um lugar híbrido de segundo pai, tio e amigo.

À minha avó Maria Paulino, por ser a mulher mais forte que conheço, sem sequer imaginar o quanto me ensina sobre a importância de realizarmos em nossas vidas a máxima de que é preciso "endurecer sem perder a ternura jamais".

À minha irmã Bruna, pelo amor e genes paternos que nos unem e por ter trazido ao mundo os meus lindos sobrinhos, Lucas e Fernanda.

Ao meu amado amigo Joel, pelas conversas existenciais e pelas melhores e mais verdadeiras risadas. Sua cumplicidade, conselhos e piadas são essenciais para a minha vida.

Ao meu mais caro amigo André, por termos superado as rivalidades escolares e termos nos tornado incentivadores acadêmicos mútuos. Mesmo de longe, suas conquistas são alegria para mim e eu sei que a recíproca é verdadeira.

À Bianca poderia dizer quase o mesmo, cujas conquistas, criatividade e força para ir adiante sempre me inspiram. Obrigada pela amizade leal de tantos anos.

À Ana Carolina, pela cumplicidade nas agruras acadêmicas, na esperança de que todas valham a alegria das nossas conquistas. Que a gente sempre tenha festas estranhas com gente esquisita, onde nem nossas danças loucas se encaixam, para comemorar a vida. 
Ao Pedro Cruz, que em tão pouco tempo trouxe música, sol, chuva, cachoeira e carnaval para essa fase sempre tão solitária de escrita, tornando a minha ilha um lugar muito melhor.

Aos amigos que fiz ao longo desses anos na PUC, entre graduação e mestrado, meu muito obrigado pela companhia nas aulas, na biblioteca, no café e no bar.

Aos queridos da minha equipe no Pré-Universitário Rubem Alves, em especial Naiana, Lucas, Gustavo, João e Ana Cláudia. Vocês e a nossa cultura tem lugar cativo no meu coração; dividir turmas, aulas, almoços, cervejas e tretas com vocês tem sido um prazer.

Aos queridos amigos da vida, em especial Ana Paula, Adriano, Eduardo, Pedro, Camilla, agradeço a compreensão pela ausência.

Pela orientação atenta, disponibilidade, paciência e dedicação, o maior agradecimento vai para o meu querido orientador e, acho que a essa altura posso dizer, amigo Diego Galeano.

Agradeço à CAPES e à PUC-Rio, pelos auxílios concedidos, sem os quais este trabalho não poderia ser realizado.

E, por último, mas não menos importante, agradeço ao Departamento de História da PUC-Rio, em especial aos funcionários Cláudio, Igor, Edna e Cleusa, por toda ajuda, atenção, paciência e carinho, cujo trabalho é imprescindível na formação de todo o corpo discente. 


\section{Resumo}

Oliveira, Priscila Sobrinho de; Galeano, Diego Antonio. Trajetórias de encarceramento nas memórias de presos políticos no Brasil das décadas de 1930 e 1940. Rio de Janeiro, 2018. 100p. Dissertação de Mestrado - Departamento de História, Pontifícia Universidade Católica do Rio de Janeiro.

A presente dissertação analisa as trajetórias prisionais de cinco militantes comunistas que, por conta das suas práticas políticas, sofreram perseguição e prisão durante o primeiro governo de Getúlio Vargas (1930-1945). Para tanto, são privilegiadas como fontes principais deste trabalho as obras autobiográficas escritas por estes homens. Buscamos entender as obras dentro dos seus contextos de escrita e publicação, mas também o que elas nos dão a ver sobre a experiência de estar preso nas Casas de Detenção e prisões insulares de Fernando de Noronha e Ilha Grande, assim como o deslocamento marítimo feito enquanto preso, durante aquelas décadas, ao que chamamos de cárcere em movimento. $\mathrm{O}$ objetivo é compreender como estes sujeitos, ao narrar as experiências de prisão, construíram a identidade de preso político e, de forma dialética, construíram também uma imagem do chamado preso comum como o seu outro, oposto, negativo e estigmatizado. Assim, a pretensão deste trabalho é contribuir para um entendimento mais complexo da experiência de prisão política vivida pelos autores nas décadas de 1930 e 1940, posteriormente narradas e tomadas como categoria pouco questionada pela historiografia.

\section{Palavras-chave}

Preso político; preso comum; memórias prisionais. 


\section{Abstract}

Oliveira, Priscila Sobrinho de; Galeano, Diego Antonio (Advisor). Imprisonment trajectories in the memories of political prisoners in Brazil (1930-1940). Rio de Janeiro, 2018. 100p. Dissertação de Mestrado - Departamento de História, Pontifícia Universidade Católica do Rio de Janeiro.

The present thesis analyses the trajectory of five left-wing activists that, due to their political activities, were persecuted and arrested during the first government of Getúlio Vargas (1930 -1945). We focus on the autobiographies and memoirs written by these men, a collection of works that make a corpus of documentary. We aim to understand their works within the contexts such texts were written and published. It is also our intent to acquire from them a vision about the experience of being a convict in the "Casas de Detenção" and insular prisons of Fernando de Noronha and Ilha Grande, as well as the transportation by the sea done as a prisoner, throughout those decades, that we denominate itinerant jail. The objective of the analytic outline is to understand how these subjects, when describing their convict experiences, built an identity of political prisoner and, in a dialectical form, also built the image of the so-called common prisoner as their other, opposite, negative and stigmatized. In this sense, the objective of this work is to contribute to a more complex understanding of the political prison lived by the authors in the decades of 1930 and 1940, later narrated and not very questioned by the historiography.

\section{Keywords}

Political prisioner; common prisoner, prison memoirs. 


\section{Sumário}

$\begin{array}{ll}\text { 1.Introdução } & 10\end{array}$

2.Memórias de presos políticos

3. Trajetórias de encarceramento 41

3.1. Atos de prisão 41

3.2. Nas Casas de Detenção 46

3.3. Nos Navios: a prisão em deslocamento 56

3.4. O cárcere final: as ilhas prisionais 60

4. Os presos comuns nas narrativas de presos políticos 71

4.1. O Coletivo 71

4.2. "A promiscuidade com a mais baixa categoria da malandragem" 79

5. Conclusão 91

$\begin{array}{ll}\text { Referências bibliográficas } & 94\end{array}$

$\begin{array}{ll}\text { Lista de Fontes } & 100\end{array}$ 


\section{Lista de figuras}

Figura 1. Capa do livro Nos Subterrâneos do Estado Novo

Figura 2. Capas dos volumes de Memórias

Figura 3. Capa de Uma vida em seis tempos (memórias)

29

Figura 4. Capa de Vida de um revolucionário (memórias)

32

Figura 5. Capa de Caminhos Percorridos (memórias de militância) 36 


\section{1 \\ Introdução}

No filme $O$ beijo da mulher aranha, baseado no romance homônimo do escritor argentino Manuel Puig e dirigido pelo cineasta brasileiro Hector Babenco, dois presos dividem a cela de uma prisão na América do Sul. Na sinopse, o primeiro preso é definido como homossexual e o segundo como prisioneiro político. O livro foi publicado em 1976, ano em que a Argentina sofreu um golpe que implantou uma ditadura militar (1976-1983), regime vivido pelo Brasil desde 1964 até 1985, ano que a adaptação cinematográfica é filmada. Os contextos de publicação do livro e de sua posterior adaptação para o cinema não são irrelevantes; antes, nos levam a pensar sobre a complexidade política presente na trama e na obra.

A película, uma produção independente e de baixo custo realizada entre Brasil e Estados Unidos, foi indicada ao Oscar de melhor filme, melhor direção e rendeu o prêmio de melhor ator à William Hurt, que interpreta o referido preso homossexual. A dualidade entre preso homossexual e preso político apresentada na sinopse do filme nos dá poucos indícios sobre a multiplicidade de questões que os personagens desenvolvem na relação que travam ao longo do filme (e do livro). O personagem preso político é um indivíduo que enxerga a política como centro da sua vida e de todas as relações que trava, enquanto o preso homossexual é um indivíduo acusado de praticar sexo com um menor de idade, que recebe acusações recorrentes de futilidade advindas do primeiro e nega com frequência a política tão cara ao outro. A dualidade inicial e superficial, ao longo da trama, vai dando lugar a emergência de questões complexas no que concerne à política, prisão, sexualidade e comportamento.

Desde os primeiros presos políticos da República, principalmente provenientes da repressão aos movimentos tenentistas, podemos ver indícios de um estigma presente na crítica que fazem, não à prisão enquanto instituição, mas à sua própria prisão quando reclamam o fato de terem sido tratados como presos comuns ou terem ocupado os mesmos espaços prisionais que os presos por crimes ditos comuns. Agildo Barata, militar e comunista, preso por participação nos levantes promovidos pela Aliança Nacional Libertadora em 1935, quando protesta 
ter sido enviado para a Casa de Detenção, diz que "este presídio era destinado a detentos da justiça comum e, assim, desde os primeiros dias de nossa prisão, a ditadura getulista evidenciava seus propósitos de relegar ao mais absoluto desprezo, qualquer respeito à nossa situação de presos políticos”, localizando o desprezo das autoridades estatais não na prisão em si, mas no fato de ter sido encarcerado em um presídio que não era apenas destinado aos presos políticos. ${ }^{1}$

Tanto $O$ beijo da mulher aranha quanto a fala de Agildo Barata em seu livro de memórias nos mostram que existem questões quanto à construção das noções de preso político e preso comum que vão além do fato de serem consequências das categorias de crimes nos quais os sujeitos são acusados e julgados. Este trabalho busca perseguir e compreender algumas destas questões em narrativas de memórias de autores que foram presos políticos nas décadas de 1930 e 1940. Além disso, buscamos também reconstituir as suas trajetórias de encarceramento, desde os atos de prisão aos cárceres que estiveram. Antes de explicar melhor como realizamos esse intento, faz-se necessário explicar como chegamos até a pesquisa que tem como produto esta dissertação.

Em 2016, a proposta de projeto de pesquisa apresentada para a seleção de mestrado tinha como objetivo dar continuidade à investigação sobre a história da prisão que existiu no arquipélago de Fernando de Noronha por quase duzentos anos, que foi iniciada ainda no final da graduação. Naquele momento, o trabalho se desenvolveu tendo como fonte privilegiada a carta de um familiar que foi preso político integralista naquela ilha-prisão durante o Estado Novo. Para compreender esta carta, a pesquisa foi na direção de interpretá-la à luz da historiografia existente sobre o tema e das Memórias de Gregório Bezerra, também preso político naquele arquipélago no mesmo período. ${ }^{2}$

Nesse primeiro momento, fizemos um esforço de localizar a prisão de Fernando de Noronha no que chamamos de "arquipélago penal" da América Latina. Esse arquipélago penal surgiu quando, após a independência, as novas

\footnotetext{
${ }^{1}$ BARATA, Agildo. Vida de um revolucionário (memórias). São Paulo: Alfa-Ômega, 1978, p. 303.

${ }^{2}$ OLIVEIRA, Priscila Sobrinho, GALEANO, Diego Antonio. "Eu aqui quase que não tenho novidades, só quando aparece vindas do mundo": Fernando de Noronha no Estado Novo através de uma experiência prisional. Monografia (graduação em História). Rio de Janeiro, PUC-Rio, 2015.
} 
nações latino-americanas iniciaram um processo de modernização de suas instituições visando se inserir no rol das nações modernas, liberais e republicanas (com exceção do Brasil, que continuou sendo uma monarquia) que incluiu a criação e modernização das prisões e dos sistemas punitivos. Assim, novas penitenciárias foram criadas ou reformadas, algumas em ilhas ou territórios longínquos. Esse processo de modernização foi conduzido pelas elites científicas, políticas e estatais, importou modelos de modernidade dos Estados Unidos da América e de alguns países da Europa e foi baseado em uma retórica liberal.

Tais instituições começaram a ser construídas em quase toda a América Latina independente em meados do século XIX. O objetivo era expandir a intervenção estatal no que diz respeito ao controle social, eliminar algumas formas de castigo consideradas infames e relacionadas à época colonial, oferecer às elites urbanas uma maior sensação de segurança e possibilitar a transformação dos indivíduos considerados delinquentes em cidadãos obedientes à lei e trabalhadores dóceis. Com tudo isso, buscava-se projetar uma imagem de modernidade da nação de acordo com modelos estrangeiros. ${ }^{3}$

É dentro desse movimento que foram idealizadas e criadas prisões como as Casas de Detenção que foram espalhadas pelas capitais do Brasil e a Penitenciaría de Buenos Aires. Também as colônias penais insulares ou em territórios distantes como o Penal de Ushuaia na Argentina e as prisões em Fernando de Noronha, no Brasil; em Ilhas Marías, no México ou Juán Fernandez, no Chile. A criação de prisões tanto em centros urbanos quanto em locais afastados, mostra a dualidade presente nos discursos acerca das punições que deveriam ser empregadas, pois instituições consideradas modernas conviveram com práticas antigas.

Essa pesquisa inicial me fez esbarrar numa espécie de lacuna historiográfica sobre Fernando de Noronha, pois a maior parte dos trabalhos analisam a prisão insular durante o século XIX, quando desempenhava um papel central dentre os cárceres do Brasil Imperial. A lacuna dizia respeito à sua

\footnotetext{
${ }^{3}$ AGUIRRE, Carlos. Cárcere e Sociedade na América Latina. Em: BRETAS, Marcos, COSTA, Marcos, NETO, Flávio de Sá, MAIA, Clarissa. História das prisões vol. 1. Rio de Janeiro: Rocco, 2009. p. $35-70$.
} 
utilização entre os primeiros anos da República até seu fechamento; sobre esse período encontramos algumas referências sobre a sua utilização pelo estado de Pernambuco até a sua transformação por um decreto no ano de 1938 em Colônia Agrícola destinada aos presos políticos e seu fechamento que teria se dado em 1942, com a criação da Base Militar. Longe de ser um obstáculo para o prosseguimento da pesquisa, essa lacuna historiográfica nos levou a questionamentos e buscas por respostas na documentação que foram fundamentais para a sua continuidade.

Para tanto, foi consultado o Fundo Fernando de Noronha sob a guarda do Arquivo Público Estadual Jordão Emerenciano, em Recife, cujo conteúdo envolve literalmente toneladas de documentos produzidos nos quase duzentos anos da prisão. Dentre a documentação examinada, as fichas de matrículas presentes em três volumes causaram uma certa inquietação. Essas fichas registram o trânsito intenso de cerca de mil presos por crimes ditos comuns entre os anos 1927 e 1947, porém entre o decreto de 1938 e 1942, Noronha é sempre referida como uma prisão política. Os presos comuns, quando mencionados nos poucos trabalhos que tratam a prisão no período, são descritos como em uma pequena quantidade ou representados com pouca importância, referidos como se estivessem ali apenas para prestar determinados serviços ao presídio que seria, então, de verdade um presídio político. ${ }^{4}$

Ora, se a principal característica apresentada por Fernando de Noronha desde a sua fundação foi ser uma colônia penal com trabalho, tendo seus presos sempre tido a responsabilidade de realizar determinadas tarefas laborais relacionadas ao trabalho penal, por que com a chegada dos presos políticos apenas os presos comuns seriam responsáveis pela prestação de serviços? Teria se tornado o presídio um espaço destinado apenas aos presos políticos, portanto um presídio político?

Assim, a intenção inicial da pesquisa era mapear e compreender qual a configuração teria tido a população prisional de Fernando de Noronha nas décadas de 1930 e 1940, momento em que os presos políticos são referidos com

\footnotetext{
${ }^{4}$ APEJE, Arquivos Permanentes, Fundo Fernando de Noronha, série Presídio Comum e Político, pastas BR/PE/APEJE/FN - 001.519; BR/PE/APEJE/FN - 001.520; BR/PE/APEJE/FN - 001.521.
} 
determinado protagonismo pois narraram suas experiências de vida e deixaram testemunhos sobre a prisão, tendo nisso uma maneira de suas vozes serem ouvidas. Ao realizar suas obras autobiográficas, acabaram por criar uma noção cristalizada das categorias de preso político e de preso comum, reproduzida pela historiografia sem muito questionamento, principalmente após a ditadura militar, como consequência compreensível da utilização da prisão para reprimir a militância em escala mais alargada do que foi feita no regime Vargas. O que levou à invisibilização dos presos comuns, em favor da narrativa dos presos políticos, na qual o protagonismo dos autores é tomado sem levar em conta a ilusão biográfica presente em suas memórias.

Se antes acreditava que essas indagações levariam ao resultado desta dissertação, outras questões fizeram mudar os rumos da pesquisa. A saber, pretendíamos dar protagonismo aos presos comuns, perseguindo os vestígios das suas experiências de prisão para além das narrativas sobre eles nas memórias dos presos políticos. Deste ponto de vista, os presos políticos eram um obstáculo para chegar aos presos comuns pois eles tiveram o monopólio da fala e seus argumentos, imagens e experiências acerca da prisão e dos presos comuns foram apropriados pela historiografia. No entanto, uma leitura mais atenta dessas memórias poderia nos permitir pensar a possibilidade de investigar, muitas vezes a contrapelo de suas próprias intenções, o processo de conformação e transformação das categorias de "preso político" e "preso comum" no Brasil. Como a imagem que constrói sobre o preso por crimes ditos comuns operava nestas narrativas e se articulava com o significado de ser preso político? A partir dessa questão, o rumo da pesquisa foi se distanciando das questões historiográficas acerca da colônia penal de Fernando de Noronha e se aproximando de questões colocadas por narrativas de memórias de autores que foram presos políticos durante as décadas de 1930 e 1940.

A partir desta nova questão, essa pesquisa foi na direção de analisar um corpus documental composto por cinco obras autobiográficas de sujeitos que, por conta da militância, foram presos durante o primeiro governo Vargas: Memórias (1979), de Gregório Bezerra; Caminhos Percorridos (memórias de militância) (1982), de Heitor Ferreira Lima; Nos Subterrâneos do Estado Novo (1950), de 
Herondino Pereira Pinto; Vida de um revolucionário (1962), de Agildo Barata; e Uma vida em seis tempos (memórias) (1976), de Leôncio Basbaum. A análise desse corpus se dá em diferentes níveis e formas ao buscar alcançar diferentes objetivos nos três capítulos que se seguem a esta introdução.

O primeiro capítulo, Memórias dos presos políticos, tem um caráter um pouco introdutório. Nele, buscamos entender as obras de forma mais geral, levando em conta o caráter subjetivo e as intenções autobiográficas presentes em cada uma. Além disso, intentamos compreender seus respectivos contextos de escrita, publicação e recepção através do que se falou sobre os títulos e os autores na imprensa de época. O objetivo é, então, entender quem foram os autores e o que os levou a escrever sobre suas experiências de vida, tendo em vista que o passado rememorado e esquecido nas memórias de um sujeito é sempre moldado por questões postas no presente da escrita e em função de expectativas futuras.

Por sua vez, o segundo capítulo, Trajetórias de encarceramento, diz respeito a um recorte analítico nas trajetórias de vida dos autores com o objetivo de realizar uma análise mais específica sobre as narrativas da experiência prisional durante as décadas de 1930 e 1940. Apesar de terem sido presos em momentos e espaços diferentes durante o regime Vargas, esses autores têm em comum uma trajetória de encarceramento. Foram presos na Casas de Detenção do estado em que ocorreram os atos de prisão e, em seguida, foram transferidos para uma prisão insular, Fernando de Noronha ou Ilha Grande. Especificamente, Agildo Barata e Gregório Bezerra, por conta da criação da Base Militar em Fernando de Noronha em 1942, acabaram sendo transferidos desta ilha-prisão para o presídio da Ilha Grande. Há também em comum o fato de todos narrarem a transferência através de deslocamento marítimo em navios, que chamamos aqui de "cárcere em movimento".

Este capítulo abre um diálogo com uma história social das prisões que trata tanto das ilhas prisionais e colônias penais quanto das Casas de Detenção. Mas também há um diálogo com uma historiografia que busca pensar o deslocamento marítimo em navios como uma experiência social, da qual temos como exemplo os trabalhos de Peter Linebaugh e Marcus Rediker e de Jaime 
Rodrigues..$^{5} \mathrm{O}$ objetivo desta parte do trabalho é pensar a passagem dos autores por esses cárceres como uma trajetória de encarceramento, buscando compreender como narraram a experiência de prisão em cada um desses espaços carcerários e o que podemos apreender sobre as impressões que tiveram e os rastros e vestígios que podem trazer à tona a vida cotidiana e as relações com as autoridades estatais que vivenciaram nas prisões referidas.

O capítulo três, Os presos comuns nas narrativas dos presos políticos, por fim, busca entender dentro da trajetória de encarceramento que recortamos como os autores, todos militantes comunistas, construíram narrativamente a categoria de preso político como uma identidade intrínseca às suas experiências de prisão. Essa construção narrativa se dá para além da existência de uma legislação especial que criminaliza a prática política que atenta contra a ordem estabelecida pelo regime Vargas. Pelo contrário, se deu na experiência cotidiana da prisão e na sua construção narrativa. De forma dialética, os autores elaboram para si uma identidade de preso político que tem na categoria de preso comum a imagem do seu outro. Significa dizer que, para o militante preso que se identifica como preso político, o seu outro oposto é o preso comum, cuja imagem é depreciada e denunciada como fruto da degeneração moral e social.

Assim, os autores se enxergam como seres humanos superiores, pois padecem o sofrimento da prisão sem deixar abalar sua militância, dando contornos de mártir ou herói à sua imagem. Isso estaria comprovado na maneira como conseguem levar e adaptar o cotidiano de militância para o espaço do cárcere, através da organização do coletivo. Por oposição dialética, os presos por crimes ditos comuns seriam a pior espécie de ser humano pois teriam ido parar na prisão por motivos vulgares, como condenações por crimes de assassinato, roubo ou estupro. A baixeza moral de sua humanidade seria provada no seu comportamento na prisão, principalmente no que diz respeito à prática da "pederastia".

A dualidade entre preso político e preso homossexual que aparece no livro e no filme $O$ Beijo da Mulher Aranha é uma temática cara a este capítulo,

\footnotetext{
${ }^{5}$ LINEBAUGH, Peter; REDIKER, Marcus Buford. A hidra de muitas cabeças: marinheiros, escravos, plebeus e a história oculta do Atlântico revolucionário. São Paulo: Companhia das Letras, 2008. RODRIGUES, Jaime. Escravos, senhores e vida marítima no Atlântico: Portugal, África e América Portuguesa, c.1760 - c.1875. Almanack, Guarulhos, n. 5, p. 145-177, 2013.
} 
mostrando que a sexualidade na prisão era uma questão dentro da esquerda, não apenas durante as ditaduras latino-americanas entre as décadas de 1960 e 1980, mas já nos anos 1930 e 1940. Esse capítulo tem, portanto, o objetivo de compreender que as categorias de preso político e de preso comum não são estáticas, mas construídas por quem teve o privilégio da fala.

Vários autores foram fundamentais para a discussão proposta nesta dissertação, mas alguns realizaram trabalhos específicos com os quais o diálogo é mais direto. Gláucia Pessoa, Marcos Costa, Peter Beattie, Roberta Silva e Grazielle Nascimento são autores que escreveram sobre Fernando de Noronha. Os três primeiros nomes têm trabalhos que buscam compreender a colônia penal durante o século XIX, apesar do trabalho de Beattie utilizar Fernando de Noronha como um estudo de caso, não como objeto, pois acredita que a ilha-prisão se constituía como um importante microcosmo onde questões socioculturais do Império do Brasil podem ser analisadas de forma privilegiada. ${ }^{6}$ Já Roberta Silva busca entender e capturar a experiência e os papéis desempenhados especificamente pelas mulheres que viveram em Fernando de Noronha entre 1817 e 1889 e Grazielle Nascimento reflete sobre as relações entre Brasil e Estados Unidos, partindo da transformação de Fernando de Noronha em base militar das Forças Armadas brasileira e norte-americana durante a Segunda Guerra Mundial. ${ }^{7}$

Ainda sobre colônias penais, temos o trabalho de Lila Caimari e Carlos Aguirre, mas também deste último com Ricardo Salvatore, em que tentam entender a relação entre povoamento e pena de prisão com trabalho nas colônias penais que existiram no Brasil, Chile, Argentina e México numa perspectiva de longa duração, entre 1800 e $1940 .{ }^{8}$ Este trabalho faz parte do livro organizado por

\footnotetext{
${ }^{6}$ PESSOA, Glaucia Tomas de Aquino. Fernando de Noronha, uma ilha--prisão nos trópicos: 18331894. Rio de Janeiro: Arquivo Nacional, 1994. COSTA, Marcos. O caos ressurgirá da ordem: Fernando de Noronha e a reforma prisional no Império. São Paulo: IBCCRIM, 2009. BEATTIE, Peter M. Punishment in paradise: race, slavery, human rights and a nineteenth-century Brazilian penal colony. Carolina do Norte: Duke University Press, 2015.

${ }^{7}$ SILVA, Roberta Duarte da. As Alamoas de Fernando : rotinas e vivências das mulheres no presídio de Fernando de Noronha no século XIX (1817-1889). Dissertação de mestrado. UFPE, Recife, 2013, 215 fls. NASCIMENTO, Grazielle Rodrigues. Fernando de Noronha e os ventos da Guerra Fria - A relação Brasil - Estados Unidos nos anos de JK. Recife, 2009. Dissertação de Mestrado, UFPE.

${ }^{8}$ CAIMARI, L. Apenas un delincuente: crimen, castigo y cultura en la Argentina, 1880 - 1955. Buenos Aires: Siglo Veintiuno Editores. AGUIRRE, C. The Criminals of Lima and their Worlds: The Prison Experience, 1850- 1935. Durham: Duke University Press, 2005.
} 
Christian de Vito e Alex Lichtenstein, em que buscam escrever uma história global do trabalho penal, diagnosticando que houve um movimento em todo o globo de utilização de mão-de-obra condenada em colônias penais. Por sua vez, Diego Pulido Esteva, no recém lançado livro sobre Ilhas Marías, busca revisar a história das três primeiras décadas do século $\mathrm{XX}$ da colônia penal que existiu no arquipélago mexicano, levando em conta sua principal característica de ter sido um espaço marcado pela relação do Estado com grupos sociais excluídos, como pequenos transgressores da lei e dissidentes políticos. Há também o trabalho de Myrian Sepúlveda sobre Ilha Grande, onde o Lazareto construído na ilha do litoral fluminense no fim do século XIX é posteriormente convertido em colônia penal, que ao longo de sua história vai servir de prisão para ébrios e vagabundos, mas também para os presos políticos das décadas que se seguem após $1917 .{ }^{9}$

Trabalhos como os de Linebaugh e Rediker e Jaime Rodrigues, já referidos acima, que pensam a viagem de navio como uma experiência social marcada por trocas, tensões e conflitos como qualquer outro espaço social também foram de extrema importância para entendermos a atenção que os autores dão ao deslocamento entre o continente e as ilhas prisionais.

Também foram importantes os trabalhos que pensam as Casas de Detenção e Correção, em especial os trabalhos de Marilene Antunes Sant'anna, que busca entender o imaginário, os discursos e as práticas cotidianas que cercavam a instituição do Rio de Janeiro no século XIX e XX, e o de Amy Chazkel, que analisa na Casa de Detenção a experiência das classes populares em suas relações com as autoridades estatais e a distância entre lei e práticas, nas primeiras décadas da República. ${ }^{10}$

SALVATORE, R. Crime and Punishment in Latin America. Durham: Duke University Press, 2001.

${ }^{9}$ LICHTENSTEIN, A., DE VITO, C. Global Convict Labour. Leiden, Boston: Brill, 2015. ESTEVA, Diego Pulido. Las Islas Marías: historia de una colonia penal. México: Secretaría de Cultura, Instituto Nacional de Antropología e Historia, 2017. SANTOS, Myrian Sepúlveda. Os Porões da República - a barbárie nas prisões da Ilha Grande: 1894-1945. Rio de Janeiro: Garamond, 2009.

${ }^{10}$ SANT'ANNA, Marilene Antunes. A imaginação do castigo: discursos e práticas sobre a Casa de Correção do Rio de Janeiro. Tese de Doutorado. Rio de Janeiro: UFRJ. CHAZKEL, Amy. Uma perigosíssima lição: A Casa de Detenção do Rio de Janeiro na Primeira República. Em: MAIA, C., NETO, F.S., COSTA, M., BRETAS, M. História das Prisões no Brasil. Rio de Janeiro, 2009, vol. 2. 
Por fim, o que buscamos foi realizar uma leitura dentre as inúmeras possíveis quando utilizamos fontes autobiográficas e memoriais. Essa leitura consistiu em analisar as perspectivas dos autores que compõem nosso corpus documental sobre as prisões em que estiveram durante as décadas de 1930 e 1940 e sobre os sujeitos com o quais travaram relações naqueles espaços. No seu livro O mundo da violência, Elizabeth Cancelli argumenta que na era Vargas, "o sistema penitenciário assumia gradualmente, depois de 1930, seu papel radicalizador: colocar sob a exclusão do mundo dos vivos certas categorias da população". ${ }^{11}$ Apesar dessa exclusão imposta pelo governo ditatorial de Getúlio Vargas, as categorias excluídas e legadas aos espaços do sistema penitenciário não eram homogêneas, nem se mantinham estáveis dentro das prisões. Longe de serem objetos inertes dentro de uma ordem repressiva que os imobilizava por completo, os presos comunistas analisados neste trabalho participaram do processo de elaboração e reelaboração das categorias de "preso político" e "preso comum" e do imaginário sobre as prisões. As batalhas narrativas que se desenvolvem nas memórias e autobiografias prolongavam, assim, uma luta cotidiana por sobreviver nos cárceres e ilhas prisionais.

Para tanto, é feito um esforço de estabelecer um diálogo entre a historiografia que compreende o período do primeiro governo Vargas de uma perspectiva de repressão política, em que o estado exerce a violência de cima para baixo sem deixar margem para agência dos sujeitos, que quando buscam essa agência, sofrem a repressão e prisão, e uma historiografia social das prisões, que nos proporciona instrumentos para reconhecer como esses sujeitos agiram apesar da repressão e da prisão.

Em resumo, buscamos reconstituir os vestígios de experiências, tentando compreender como elas são articuladas nas narrativas autobiográficas, levando em conta a subjetividade dos autores, os contextos de escrita e publicação, desessencializando categorias pouco questionadas nos trabalhos historiográficos, mostrando que a experiência e a narrativa possibilitaram a articulação dialética das categorias de preso político e preso comum como outros opostos. Mas também o que a narrativa dessas trajetórias de prisão mostra sobre a vida social

\footnotetext{
${ }^{11}$ CANCELLI, Elizabeth. O mundo da violência: a polícia na Era Vargas. Brasília: Editora Universidade de Brasília, 1993. p. 180.
} 
encontrada e vivida pelos autores no cárcere, mostrando que, apesar do aparato político-repressivo, os sujeitos desenvolviam estratégias de sobrevivência social e de ampliação das margens de liberdade dentro das possibilidades encontradas e negociadas com as autoridades estatais dentro da prisão.

De Graciliano Ramos à Madame Satã, que não fazem parte do nosso corpus documental mas são peças fundamentais para construir o campo no qual essa dissertação se insere, há toda uma produção de escritos, cartas, relatos de memórias, diários, entrevistas, etc. concebidos por presos durante ou sobre a experiência prisional. Estas fontes nos mostram o quanto aqueles homens mantiveram uma relação ativa com o mundo exterior, mesmo tendo a sua liberdade circunscrita à prisão. Como exemplos da historiografia que explora esses escritos de prisão como fontes, temos o livro The Criminals of Lima and their Worlds, de Carlos Aguirre, o trabalho Remembering freedom: life as seen from the prison cell, de Lila Caimari e Les livres des viés coupables, de Philippe Artières. Este último, por sua vez, afirma que a prisão, por vezes, constitui-se como uma "fábrica de textos", visto que a escrita é uma atividade à qual indivíduos presos frequentemente dedicam boa parte de seu tempo no cárcere. ${ }^{12}$

O objetivo último deste trabalho constitui-se, portanto, em contribuir com este campo da historiografia que compreende a prisão desde a perspectiva dos presos, neste caso políticos, buscando compreender como construíram estratégias de sobrevivência social na clausura, como se relacionaram entre si e com os outros que encontraram na prisão.

12 AGUIRRE, Carlos. The Criminals of Lima and their Worlds: The Prison Experience, 18501935. Durham: Duke University Press, 2005. CAIMARI, Lila. Remembering freedom: life as seen from the prison cell. In: AGUIRRE, C. SALVATORE, R. Crime and Punishment in Latin America. Durham: Duke University Press, 2001. ARTIÈRES, Philippe. Les Livres de Vies Coupables: autobiographies de criminels (1896-1909). Paris, Éditions Albin Michel, 2000. 


\section{2}

\section{Memórias de presos políticos}

A escrita de si diz respeito a um conjunto de práticas de produção de subjetividade que podem englobar desde as mais diretas ações, como as autobiografias e os diários, ou mais indiretas, como o acúmulo de objetos materiais, com a intenção de resultar em coleções ou não. A prática de escrever sobre si é algo antigo, mas com a emergência da noção de individualidade do mundo moderno ganhou novos significados. O indivíduo moderno, então, passou a se entender como dotado da capacidade de atribuir significados ao mundo que o rodeia e assim tomou consciência da capacidade de construir sua própria identidade através da subjetividade. É a partir desse momento que emerge também a noção de que uma vida é uma história, isto é, um conjunto de acontecimentos que podem ser concebidos como um relato ou uma narrativa. ${ }^{1}$

Este capítulo dedica-se a realizar uma análise inicial do corpus documental composto por cinco obras autobiográficas, onde seus autores buscaram atribuir significados ao mundo no qual se inseriam ao mesmo tempo que construíam sua própria identidade enquanto sujeitos. Em comum, esses livros tem o fato de terem sido escritos por homens que foram presos no período que compreende o primeiro Governo Vargas, em razão da militância política. Os autores também compartilham trajetórias de prisão semelhantes, caracterizadas pela passagem por determinados cárceres específicos, como a Casa de Detenção do Rio de Janeiro, de Fortaleza e de Recife e as colônias penais insulares localizadas em Fernando de Noronha, litoral de Pernambuco, e Ilha Grande, litoral do Rio de Janeiro. Há também o fato de três dos cinco livros terem sido escritos e publicados durante a Ditadura Militar (1964-1985) e de todos os autores terem atuado na militância de esquerda e terem tido vidas completamente atravessadas pelos acontecimentos históricos do período. As exceções são livros publicados em 1950 e 1962 - que tem por isso algumas especificidades em relação aos outros e tendo este último sido republicado em 1978.

\footnotetext{
${ }^{1}$ GOMES, Ângela de Castro. Escrita de si, escrita da História: a título de prólogo. In: GOMES, A. C. (Org.). Escrita de si, escrita da História. Rio de Janeiro: FGV, 2004.
} 
Levando em conta que a escrita autobiográfica é feita de relatos de memórias sobre acontecimentos e experiências de uma vida, precisamos sublinhar que as lembranças e esquecimentos, os silêncios, as emoções, os saberes, as lacunas, as fraturas e idiossincrasias são partes constitutivas da narrativa. E que para analisar o nosso corpus documental, precisamos entender quem foram os sujeitos que o produziu e o contexto e as razões que levaram estes homens a escrever sobre si, buscando compreender que o passado que se rememora e se esquece é sempre mobilizado por questões postas no presente da escrita e em função de expectativas futuras. ${ }^{2}$

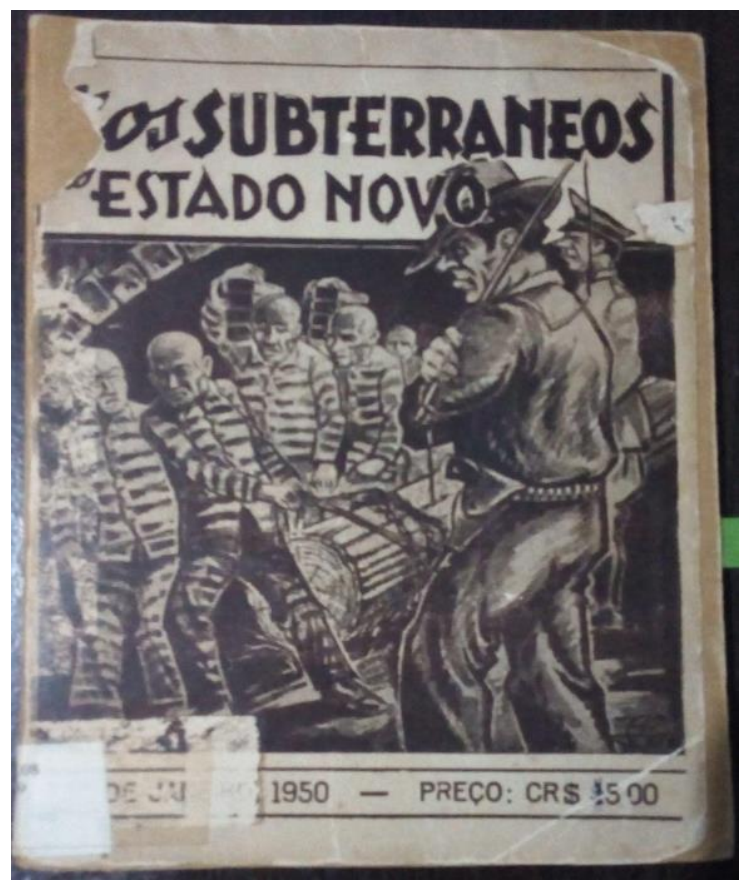

A primeira obra que compõe o corpus documental analisado é o livro intitulado Nos subterrâneos do Estado Novo de Herondino Pereira Pinto. Heron ou Herondino Pereira Pinto foi um jornalista e sindicalista, preso em 1935 e libertado por ocasião da chamada "Macedada" em $1937 .{ }^{3}$ Naquele mesmo ano, Heron ingressou no jornal A Rua, onde publicou os textos sobre sua experiência de prisão como reportagens, compendiados posteriormente e publicados em 1950 no Rio de Janeiro pela editora Germinal. Sobre a editora, não temos informações

\footnotetext{
2 JELÍN, Elizabeth. ¿De qué hablamos cuando hablamos de memoria?. In: JELÍN, E. Los trabajos de la memoria. Espanha: Siglo Veintiuno Editores, 2001.

3 "Macedada" foi como ficou conhecida a libertação de cerca de 400 presos sem processo formal realizada pelo Ministro da Justiça e Negócios Interiores, José Carlos de Macedo Soares, em 1937.
} 
além do fato de apenas estar identificada por um carimbo na folha de rosto da publicação, que contém também o número de uma "Caixa Postal da Lapa Rio de Janeiro", o que nos leva a acreditar que era sediada naquele bairro carioca e que o livro foi produzido no Rio de Janeiro. Porém, o periódico Diário Carioca de 14 de setembro de 1950 afirma que a "editora Panfleto Ltda., lançará dentro de poucas horas exclusivamente nas bancas de jornais, este livro do jornalista Heron P. Pinto", o que nos faz pensar na possibilidade da editora Germinal ter sido um selo desta editora Panfleto, da qual também não localizamos informações. ${ }^{4}$ Dessa forma, esse livro é a exceção do nosso corpus documental e merece uma atenção diferente por não ter sido escrito entre as décadas de 1960 e 1980, mas ser um escrito de época com publicação em contexto específico.

Além dos textos publicados como reportagens assim que o autor deixa a prisão, o livro é composto pelo prefácio datado de 25 de agosto de 1950 e assinado por Edmundo Moniz ${ }^{5}$, um texto dos editores intitulado "Impressionantes relato [sic] do autor, que esteve encerrado nas masmorras da Casa de Detenção e da Colonia de Dois Rios" e um texto direcionado "Aos Leitores", que não é assinado mas provavelmente foi escrito pelo próprio Pereira Pinto. Há também uma citação de trecho referido como "Do ensaio historiográfico do escritor Sylvio Julio - 1949”. Daí para frente, o caráter de reportagem e denúncia tende a ficar mais exposto e direto com o que entendemos ser uma introdução para os leitores que por ventura sejam leigos acerca do período do primeiro governo Vargas intitulada "Sintese dos Acontecimentos Políticos". Essa parte tem como característica o objetivo de explicitar de maneira didática o contexto em que os fatos denunciados aconteceram. Ao final dos quatro capítulos, há uma seção chamada "Documentário", que reúne reportagens de jornais de época, numa tentativa de corroborar as informações relatadas e os crimes e violações de direitos ocorridas durante o regime de Vargas.

A necessidade de afirmar a legitimidade dos fatos ali relatados e o tom acusatório e de denúncia sobre a repressão e arbitrariedades ocorridas durante as décadas de 1930 e 1940 é uma característica que percorre o livro inteiro, inclusive com acusações nominais diretas ao presidente e seu chefe de polícia Filinto

\footnotetext{
4 "Nos subterrâneos do Estado Novo", Diário Carioca, 14 de setembro de 1950.

5 Edmundo Moniz (Salvador, 1911-1997) foi um jornalista e escritor marxista. Trabalhou no Correio da Manhã e no Instituto Histórico e Geográfico Brasileiro.
} 
Muller, com referências às prisões como "masmorras", "túmulos dos vivos", "ilha dos suplícios" e dos presos políticos como "escravos do Estado Novo".

Infelizmente o livro não traz nenhuma indicação de quem realizou o trabalho da capa, que traz uma ilustração que remete diretamente ao conteúdo de denúncia do pequeno livro. São homens com semblantes muito parecidos, de aparência cansada, cabeças raspadas, vestidos com roupas listradas típicas de presidiários que carregam tijolos e uma grande tora de madeira. Vigiam o trabalho forçado dois guardas com olhar fulminante, de prontidão e armados - apesar do revólver estar ao contrário no coldre do primeiro guarda. A imagem antecipa a denúncia de Herondino Pereira Pinto: o Estado Novo tratou os presos políticos como escravos que realizavam trabalhos forçados vigiados por capatazes nos tempos coloniais.

O tom e teor colérico da narrativa é sempre acompanhado da acusação e atribuição de culpa, tanto à história por ter envolvido o autor naqueles acontecimentos, quanto aos homens que, segundo ele, dirigem bem ou mal os fatos dos quais se faz a história. Por conta disso, diz que "o ex-ditador não pode fugir à regra de um princípio incontestável, tecendo-a [a história] com os sacrifícios de um povo, para sublimação de sua ambição pessoal" e que, para alcançar seus objetivos ambiciosos, Vargas teve "colaboradores eficientes e dedicados discípulos cujos nomes o povo brasileiro guardou, muito embora ainda estejam usufruindo cargos e vantagens nos altos postos da administração pública"6. Assim, o autor aponta que Vargas é o principal responsável pelo regime antidemocrático que instaurou, mas também acusa aqueles que o apoiaram e deram sustentação ao seu governo, pois este não teria sido possível se não houvessem colaboradores empenhados em colocá-lo em prática. Demonstra também que havia uma continuidade no poder entre aqueles homens que denuncia na publicação, mesmo que Vargas não fosse então o governante.

Para Pereira Pinto e os sujeitos envolvidos na publicação do livro, aquele momento deve ter parecido oportuno para trazer à tona as reportagens escritas após a saída da prisão pois com aproximação das eleições de 1950, todos viam que a possibilidade de Vargas voltar à presidência do país era real, afinal a votação bastante expressiva para deputado e senador em 1946 era uma grande

\footnotetext{
${ }^{6}$ PINTO, Herondino Pereira. Nos Subterrâneos do Estado Novo. Rio de Janeiro: editora
} Germinal, 1950, p. 13. 
demonstração de apoio popular. Tanto é que Edmundo Moniz no primeiro parágrafo do Prefácio afirma:

"Não poderia haver melhor oportunidade, como a que existe, presentemente, para a publicação de um trabalho verídico, sincero e consciencioso, sobre as monstruosas violências cometidas, entre nós, pela polícia, durante o Estado Novo. "7

De fato, em 1949 Vargas lança sua campanha oficialmente, tendo como mote eleitoral a independência econômica do país através de um programa de incentivo à industrialização que priorizava a indústria de base. A oportunidade para lançamento de Nos subterrâneos do Estado Novo estava então lançada e o pequeno livro foi publicado como um panfleto de denúncia, exclusivamente encontrado em bancas de jornais pelo valor de CR 5.00 - o que equivalia a aproximadamente ao valor de cinco exemplares de jornais da época. ${ }^{8}$ Seu objetivo claro ao realizar tais denúncias e ser tão acessível a quase qualquer pessoa era promover uma campanha contra a reeleição de Vargas, evitando que voltasse ao poder agora "nos braços do povo", como dizia o slogan de sua campanha. Objetivo esse que foi frustrado pois Getúlio Vargas teve uma vitória indiscutível nas urnas: recebeu 4 milhões de votos, o que significava 48,7\% do total, contra os 29,7\% do Brigadeiro Eduardo Gomes e 21,5\% de Cristiano Machado, seus opositores.

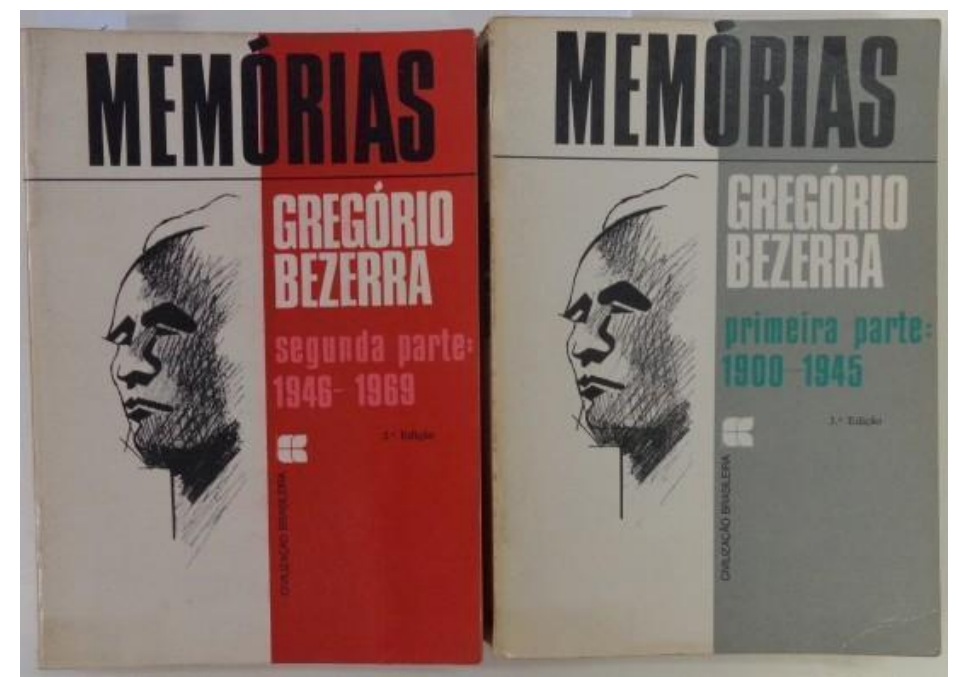

\footnotetext{
7 MONIZ, Edmundo. Prefácio. Em: PINTO, H.P. Nos Subterrâneos do Estado Novo. Rio de Janeiro: editora Germinal, 1950, p. 9.

8 "Nos subterrâneos do Estado Novo", Gazeta de Notícias, 14 de setembro de 1950. - Os jornais de grande circulação em 1950 variavam entre um valor de 90 centavos a CR \$1,00.
} 
A imagem anterior mostra as capas dos dois volumes que compõem a primeira edição da segunda obra analisada em nosso corpus documental, as Memórias de Gregório Bezerra, originalmente publicada em 1979, ocasião em que o autor retornou ao Brasil na condição de anistiado político após exílio de quase dez anos em Moscou. A editora original era a Civilização Brasileira, fundada em 1932 com a proposta de publicar clássicos da literatura, sociologia e economia; apesar de existir até hoje, como um selo do Grupo Editorial Record, não contém a obra de Bezerra em seu catálogo.

Com ilustração do rosto do autor em um semblante heroico, a capa dos volumes da primeira edição difere bastante da segunda edição publicada em 2011, que traz uma foto do autor em abril de 1964 na qual aparece sem blusa e descalço sentado no chão do pátio do Quartel de Motomecanização do bairro de Casa Forte, Recife, e vigiado por um guarda empunhando uma baioneta. Tal mudança nos dá indícios para crer que o que deve chamar a atenção do potencial leitor é o Gregório Bezerra enquanto preso político na ditadura militar e não mais o Gregório Bezerra símbolo heroico das causas nacional e comunista. Sai de centro a questão da militância sinônimo de orgulho e entra a da prisão, tortura e exílio sofridos por muitos que se opuseram ao regime. A nova edição da sua autobiografia foi publicada pela Boitempo Editorial, agora em volume único e com alguns anexos que tornam a obra mais robusta. ${ }^{9}$ Esta é a edição que utilizamos aqui e que conta com texto de apresentação de Anita Leocádia Prestes e com textos de homenagem à Gregório Bezerra escritos por Florestan Fernandes e Eduardo Campos, poesias de Ferreira Gullar e Francisco Julião, as “Alegações finais em favor de Gregório Lourenço Bezerra" feitas por Mércia Albuquerque na ocasião de seu julgamento em 1967, assim como cartas trocadas pela advogada e pelo autor. Há também uma "Mensagem de Gregório Bezerra aos camponeses", depoimentos de figuras como Luiz Carlos Prestes, Ênio Silveira e Jorge Amado e uma série rica de fotos. ${ }^{10}$

\footnotetext{
${ }^{9}$ A Boitempo é uma editora criada em 1995 por Ivana Jinkings (1961, Belém do Pará), com opções editoriais voltadas às temáticas caras para a esquerda, tendo catálogo que compreende diversas áreas das ciências humanas e sociais e literatura. Jinkings também é editora e filha do líder comunista e jornalista Raimundo Jinkings (1927-1995), que exerceu importante liderança na região amazônica e foi responsável pela fundação da primeira Boitempo nos anos 1960.

${ }^{10}$ Florestan Fernandes (1920-1995) foi sociólogo e professor da USP. Eduardo Campos (19652014) foi economista e governador de Pernambuco, falecido em 2014 quando concorria à presidência do Brasil. Ferreira Gullar (1930-2016) foi escritor, crítico de arte, tradutor. Francisco Julião (1915-1999) foi político, advogado e líder das Ligas Camponesas. Mércia Albuquerque,
} 
O texto autobiográfico é dividido em duas partes cronológicas: a primeira vai do seu nascimento na cidade de Panelas de Miranda, em Pernambuco no ano de 1900, até sua eleição como deputado federal em 1945 pelo PCB; a segunda parte vai de 1946 até 1969, ocasião do sequestro do embaixador norte-americano Charles Elbrick pelo Movimento Revolucionário Oito de Outubro (MR-8), em que é exigida a libertação de quinze presos políticos, dentre os quais encontrava-se seu nome. Por conta disso, o autor foi libertado e enviado para o México, em seguida para Cuba e depois para a União Soviética, onde finalmente fixou residência em Moscou e recuperou-se dos problemas de saúde causados pela tortura e prisão. Voltou em 1979 ao Brasil, com a revogação do Ato Institucional n 5 e o decreto da Lei de Anistia e publicou, então, suas Memórias. Com o processo de redemocratização, lançou-se como candidato ao cargo de deputado federal pelo Partido do Movimento Democrático Brasileiro, mas alcançou apenas a suplência. Acometido por câncer, faleceu em 21 de outubro de 1983, aos 83 anos na cidade de São Paulo.

Para explicar o que o levou a escrever suas memórias de vida, Bezerra afirma que vivia exilado em Moscou quando recebeu "uma tarefa que os meus amigos me deram, pressionados pela juventude que só conhece a minha vida por alto e que exigiram que eu acabasse de escrever as minhas memórias. Tenho que dar conta do recado, né! "11 Nas Memórias, o autor narra sua trajetória de vida ao mesmo tempo que apresenta os acontecimentos mais importantes da vida política brasileira do século XX e dos quais várias vezes esteve em posição de protagonista. Dessa forma, a vida pessoal, a militância política e a história do Brasil acontecem de forma intrinsecamente relacional na obra cuja narrativa se desenvolve quase como uma história épica, cabendo ao autor o papel central de herói.

Nascido no Agreste pernambucano, Bezerra teve uma infância extremamente pobre, como a maior parte da população camponesa nordestina. Aos 17 anos, ele já trabalhava como operário da construção civil e com as notícias

falecida em 2003, foi advogada pernambucana, conhecida por ter defendido cerca de 500 presos políticos brasileiros durante a ditadura militar; recém-formada em 1964, ela decidiu que iria advogar em favor de Gregório ao presenciar as agressões sofridas nas ruas de recife. Luiz Carlos Prestes (1898-1990) foi político e militar brasileiro. Ênio Silveira (1925-1996) foi editor e diretor por muitos anos da editora Civilização Brasileira. Jorge Amado (1912-2001) foi escritor brasileiro. ${ }^{11}$ BEZERRA, Gregório. Entrevista concedida ao periódico alternativo O Pasquim. Paris, 14 de janeiro de 1979. 
da Revolução Russa de 1917, teve o primeiro contato com as ideias comunistas, cuja identificação aparece quase como automática pois ele teria passado a ver nas ideias revolucionárias soviéticas a saída para todo o sofrimento que ele, sua família e seu povo pereciam por conta da desigualdade socioeconômica. Naquele mesmo ano, Bezerra seria preso pela primeira vez, ao participar de manifestações contra o governo de Pernambuco. Somando-se o tempo de pena desta primeira prisão aos 17 anos e todas as outras vezes que foi preso em toda a sua vida, o autor passou quase vinte e três anos encarcerado, dos quais quase dez anos foram nas colônias penais de Fernando de Noronha e Ilha Grande durante o regime Vargas.

A obra de Gregório Bezerra parece ter sido muito bem recebida nos meios literários brasileiros. O Diário de Pernambuco, em uma resenha que ocupava metade da sexta página do periódico, aproveitava para criticar os historiadores enquanto exaltava a autobiografia de Bezerra como importante trabalho que testemunhava e denunciava com riqueza de detalhes a situação dos camponeses pernambucanos e lançava luz sobre o movimento revolucionário de 1935 ao "trazer novas informações e outra ótica para futuras interpretações históricas" e que

"acostumados que estamos a lidar com uma historiografia de cronistas de Província, ou com livro de memórias de doces e alfenins das casas grandes, ou ainda com literatos travestidos de historiadores, poderemos passar por cima de tão ricas informações históricas que estas memórias nos legam". ${ }^{12}$

Algumas semanas depois, o mesmo periódico trouxe em pequena nota a informação de que a primeira edição das Memórias de Bezerra era "o livro mais vendido em todo o Brasil, atualmente", porém sem apresentar os números de vendagem. ${ }^{13}$ Quase três meses depois, o jornal apresenta uma nota que afirma que a obra estava totalmente esgotada e que a editora Civilização Brasileira informava o lançamento de uma nova edição ainda naquele mês. ${ }^{14} 15$

\footnotetext{
12 “As Memórias de Gregório Bezerra”, Diário de Pernambuco, 17 de junho de 1979.

13 "O livro mais vendido...", Diário de Pernambuco, 29 de julho de 1979.

14 "Painel”, Diário de Pernambuco, 14 de outubro de 1979.

${ }^{15}$ Segundo o Jornal do Brasil, o primeiro e o segundo volumes das Memórias custavam CR\$ 250,00 e CR \$ 200,00, respectivamente. "Livros que você deve ler e ter em sua biblioteca", Jornal do Brasil, 6 de outubro de 1979.
} 


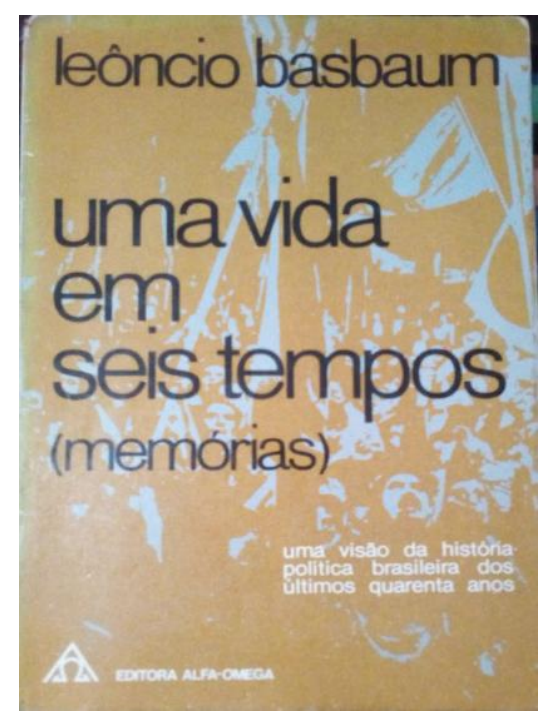

Uma vida em seis tempos - memórias, de Leôncio Basbaum é a terceira obra aqui analisada. Ao contrário do livro de Herondino Pereira Pinto, que se propõe abertamente a ser uma denúncia do regime Vargas, o texto presente na contracapa do livro afirma que este "não é um livro de denúncias, " mas "a posição pessoal de um intelectual, cuja vida esteve profundamente vinculada ao movimento operário brasileiro e que [...] sempre pugnou por um socialismo autêntico e honesto". Podemos entender que o autor busca legitimar seu livro de memórias como uma obra intelectual, indo além de uma obra de memórias de militância ou de um manifesto político. Já uma nota do Jornal do Brasil ignora a dimensão autobiográfica e afirma que o livro se constitui como "uma análise histórica do Partido Comunista do Brasil, desde o 'obreirismo' até 'os descaminhos eivados de oportunismo a que foi conduzido pelo grupo baiano', nos anos 40", demonstrando como é possível fazer inúmeras leituras da autobiografia de Basbaum, inclusive ignorando o caráter de subjetividade fundamentalmente presente na obra. ${ }^{16}$

Seu filho, Hersch Wladimir Basbaum, em texto para o mesmo periódico demonstra concordar com essa leitura, em que o PCB figura como centro das memórias do autor e as críticas duras feitas por ele aos companheiros em ocasiões que provocaram cisões nas correntes internas do Partido são vistas como importantes para entender não só as décadas 1930 e 1940, como o PCB e as transformações vividas pela esquerda entre o fim dos anos 1960 e a década de

16 “Livros”, Jornal do Brasil, 24 de junho de 1976. 
1970. Hersch Basbaum é direto e não mede palavras, chama Carlos Marighella e Joaquim da Câmara Ferreira de "velhos stalinistas" e "velados inimigos íntimos" de seu pai e se refere à militância armada em resistência à Ditadura como um “movimento terrorista". Através da crítica à esquerda brasileira dos anos 1970, Hersch afirma que para entender Uma vida em seis tempos seria preciso compreender a "impossibilidade de entender o mundo e apontar soluções através de posturas alicerçadas em visões dogmáticas" e que a grande questão do livro seria, na verdade, "como explicar, portanto, a abdicação de LB à sua própria vida? [...] Por que ser um militante revolucionário? ". ${ }^{17}$

Além do relativamente longo artigo escrito pelo filho, que ocupa a maior parte da décima primeira página da publicação daquele dia, e que situa e relaciona a autobiografia do autor dentro do conjunto de sua obra, encontramos algumas referências aos seus livros que versam sobre história e filosofia escritas em textos de periódicos que analisam a situação política e social. Porém sobre Uma vida em seis tempos encontramos raras referências, dentre as quais as mais relevantes são as que mostram o livro aparecendo em $9^{\circ}$ lugar e depois em $7^{\circ}$ lugar dentre os livros de não ficção mais vendidos, segundo o periódico Diário do Paraná. ${ }^{18}$

Nascido em Recife no ano de 1907, Basbaum era um dos onze filhos de um casal de judeus imigrantes da Bessarábia (atual Moldávia). Cursou a Faculdade de Medicina da Praia Vermelha mas exerceu por pouco tempo a profissão de médico. Conta que nas primeiras férias da faculdade, de volta à Recife para rever a família, teve seu primeiro contato com as ideias e a militância comunista e, de volta a Rio entraria em contato direto com Astrojildo Pereira. Os encontros com Astrogildo e outros nomes da geração que fundou o PCB e sua filiação em 1926 são momentos que precedem uma história de vida e militância intensa e ativa de Basbaum, tendo ele inclusive sido o responsável pela criação da Juventude Comunista Brasileira e participado do Congresso da Internacional Comunista em 1928, na União Soviética, como integrante da delegação brasileira.

Dedicou, então, boa parte de sua vida ao PCB e foi preso várias vezes por conta da militância - a exceção é ter sido poupado da prisão em 1935 por não ter participado das insurreições, pois havia sido expulso do Partido por conta de

\footnotetext{
17 "O revolucionário, um eterno romântico" de Hersch W. Basbaum, Jornal do Brasil, 7 de março de 1977.

18 “Livros mais vendidos", Diário do Paraná, 5 de setembro de 1976 e 4 de março de 1978.
} 
disputas internas, sendo reincorporado em 1936 e afastado novamente no ano seguinte. $\mathrm{O}$ autor também ajudou a criar a editora Vitória, ligada ao PCB e, após ter se desligado de vez na década de 1950, fundou sua própria editora, a Agência Literária (Edaglit). Nela, que foi fechada logo no início da ditadura militar, Basbaum publicou alguns de seus livros, como No estranho país dos iugoslavos (1962) e História Sincera da República (1962), posteriormente publicados pela Alfa-Ômega - editora fundada em 1973, em São Paulo. Tanto Uma vida em seis tempos, quanto os quatros volumes de sua História Sincera da República ainda fazem parte do catálogo desta editora.

O autor faleceu em 1969, na cidade de São Paulo, apenas três meses após ter terminado de redigir estas memórias e, por conta disso, não teve tempo de corrigir o texto original. A editora então publicou o material assim como recebeu, sem nenhuma edição, "por respeito à sua memória, e por temer que qualquer interferência pudesse prejudicar o estilo e até o pensamento do autor", diz a nota dos editores. A primeira edição foi publicada em 1976, mas aqui utilizamos a $2^{\mathrm{a}}$ edição revista de Uma vida em seis tempos, do ano de 1978 e que faz parte da série Biblioteca Alfa-Ômega de Cultura Universal.

Basbaum divide a sua vida cronologicamente em "seis tempos" e, por isso, o livro é composto por seis capítulos - Tempo dos sonhos, Os tempos ásperos, Os tempos burgueses, $O$ tempo da desilusão, O tempo da desesperança e $O$ tempo da afirmação -, além da Introdução, da Nota da Editora e de um Apêndice com duas cartas endereçadas à Luís Carlos Prestes e a carta do líder comunista escrita em resposta.

Sobre o que o levava a escrever um livro de memórias, o autor afirma que existiriam muitas motivações para um indivíduo levar a cabo tal empreendimento, mas que não sabe em qual delas encaixaria as suas. Entretanto, ao completar sessenta anos, algumas perguntas teriam começado a "aflorar" em seu espírito, fazendo-o questionar se valeu a pena ter vivido a vida que viveu e o que fez por si e pelos seus semelhantes. Assim, teria sido a "convicção de que a vida representou algo mais do que fiz ou tentei fazer" que o levava a escrever pois acreditava ter "algo para dar ao mundo: a minha experiência de um homem que viveu dentro do mundo, que não apenas o olhou de longe, mas de dentro dele, que sentiu e viveu 
os seus problemas, que pensou, escreveu e, sobretudo, agiu, pois é a ação que marca uma vida. $" 19$

Basbaum também demonstra ter consciência de estar legando uma provável contribuição para a história do PCB e assegura que apenas relatou acontecimentos e eventos que presenciou ou participou, mostrando assim "como [o Partido] nasceu, viveu e morreu", afinal ele dedicou mais de quarenta anos à militância e desempenhou papéis importantes dentro do Partido. Sobre isso afirma que a contribuição que dá para a história do PCB é "mais do que uma história política: será antes uma história humana, o lado humano da atividade revolucionária. "20

A autobiografia, então, tem tom de balanço da vida de militância. Nela, as prisões sofridas pelo autor aparecem como parte consequente, nada de extraordinário, enquanto sua vida pessoal e familiar tende a aparecer como algo secundário na maior parte da narrativa, sendo dada mais atenção quando o autor passa por problemas financeiros e precisa buscar novas maneiras de sustentar sua família do que quando nasce algum dos seus filhos.

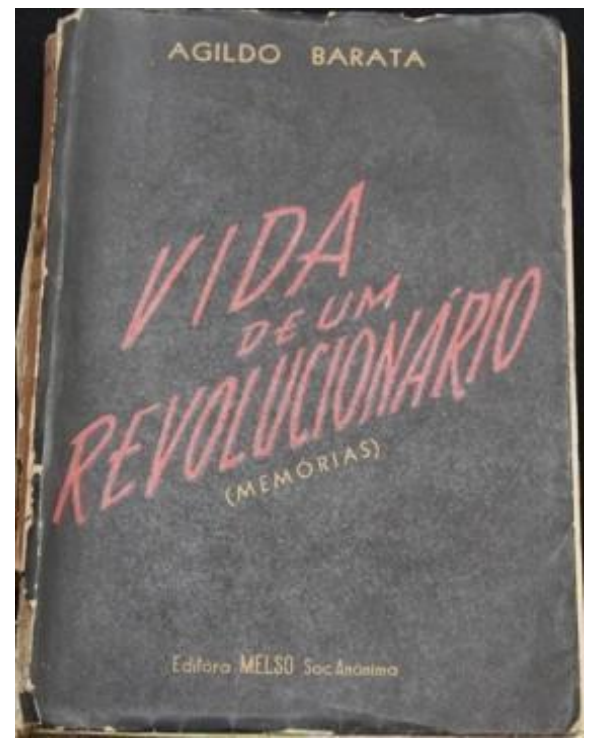

A quarta obra do corpus documental é Vida de um revolucionário (memórias), de Agildo Barata. Nascido em 1905 e falecido em 1967 no Rio de Janeiro, Agildo da Gama Barata Ribeiro ficou órfão muito jovem, o que o levou a

\footnotetext{
${ }^{19}$ BASBAUM, Leôncio. Uma vida em seis tempos (memórias). São Paulo: Alfa-Ômega, 1978, p. XIV e XV.

${ }^{20}$ Ibid., p. XVI.
} 
passar parte da infância na casa de seu irmão mais velho no Rio Grande do Sul, voltando, porém, a residir na então Capital Federal aos 20 anos para cursar a Escola Militar de Realengo. Mais tarde, incorporado ao $1^{\circ}$ Regimento Militar, o autor integrou o grupo de tenentes revolucionários liderados por Juarez Távora. E, em 1930, sendo designado para servir no $22^{\circ}$ Batalhão de Caçadores da Paraíba, Barata destacou-se ao percorrer alguns estados nordestinos durante a Revolução que levou Getúlio Vargas ao poder.

Mais tarde, decepcionado com os rumos do governo Vargas, Barata envolveu-se com a Revolução Constitucionalista de 1932, e por consequência disso, foi preso e exilado em Portugal, onde se aproximou das ideias socialistas. Quando de volta ao Brasil, foi reincorporado ao Exército, aproximou-se do Partido Comunista e dedicou-se à organização da Aliança Nacional Libertadora nos meios militares. Dessa forma, Barata participou do comando do movimento revolucionário ocorrido nos quartéis do Rio de Janeiro, em 1935, e assim como Gregório Bezerra, isso o levou a passar quase dez anos como preso político em prisões e o fez perder sua patente militar.

Em liberdade, Barata foi eleito vereador no Rio de Janeiro pelo PCB em 1947, quando o partido perderia seu registro após dois anos de funcionamento legal e os parlamentares comunistas teriam seus mandatos cassados no ano seguinte. Em 1957, assim como Leôncio Basbaum, Barata deixaria definitivamente o Partido por ter sua defesa de uma posição de radicalização democrática das estruturas do PCB negada pelos partidários, quando da ocasião em que discutiam uma resposta a ser tomada em relação ao relatório divulgado por Kruschev no XX Congresso do Partido Comunista da URSS, em que denunciava os crimes de Stálin.

Em sua autobiografia, Agildo Barata busca registrar sua vida e os acontecimentos que participou, buscando constantemente reafirmar seu protagonismo na história da esquerda brasileira. Afirma ter como razão para contar suas memórias a necessidade de tornar público os aspectos de sua vida que teriam influenciado a sua formação como revolucionário por ter participado de eventos entendidos como revoluções pois buscavam subverter a ordem das coisas. Logo, o título da obra tem um sentido literal para o autor: Barata, apesar de ter sido tenente, parlamentar e militante do PCB, definia a si mesmo como um 
revolucionário pois acreditava que as lutas políticas nas quais se envolveu ao longo da vida que definiram sua identidade.

Para justificar sua identificação como revolucionário como algo quase inato, afirma possuir uma rebeldia que norteou toda a sua vida pública e que teve como causa a vida difícil que teve a sua mãe:

"Uma sociedade, uma ordem de cousas que mata de inanição uma pessoa de tão marcantes qualidades, como as tinha minha mãe, e mantém, na opulência e na fartura, tantos e tantos canalhas, é uma ordem de cousas que não merece senão o repúdio e o combate. "21

É importante que percebamos também que a constante afirmação de que sua vida foi a vida de um revolucionário é provavelmente a buscar por responder às acusações que sofrera dos antigos companheiros após a sua expulsão do PCB, que obviamente o autor alega serem calúnias.

Aqui utilizamos a segunda edição da obra, publicada pela Editora AlfaÔmega em 1978 e que, apesar de fazer parte da série Biblioteca Alfa-Ômega de Ciências Sociais, não encontramos mais no catálogo atual. Segundo a nota da editora, essa edição contém o texto original da obra, cuja primeira edição foi publicada pela editora Melso S.A. em 1962, tem uma capa simples onde o título grande em vermelho chama atenção sobre o fundo preto. Republicada dezesseis anos após a primeira edição por decisão da família, que talvez entendesse que o contexto do fim dos anos 1970 era propício político e socialmente para a releitura das memórias de um autor que se pensava como um revolucionário convicto e que o clima político começava a se tornar menos repressivo, com a greve dos operários do $\mathrm{ABC}$ paulista marcando o retorno dos movimentos operários às ruas e com o fim da censura prévia à imprensa.

Notícias sobre o Vida de um revolucionário (memórias) são encontradas em vários periódicos da época. Para informar que Barata estava escrevendo um livro de memórias, "que conta a história política do país nos últimos 30 anos", o periódico Diário de Notícias destacava na coluna Sinal Aberto que "Agildo Barata vai contar a história". Poucos meses mais tarde, uma nota comentava que Barata havia assinado com a editora Melso e que o livro seria lançado em tempo recorde pois os originais já haviam sido encaminhados ao prelo. Alguns meses depois, a coluna "Encontro Matinal”, comunicava que o livro havia sido lançado e o Jornal

${ }^{21}$ BARATA, Agildo. Vida de um revolucionário (memórias). São Paulo: Alfa-Ômega, 1978, p.7. 
do Brasil, publicava trecho do capítulo das memórias em que o autor havia registrado as impressões sobre a convivência com o líder comunista Luís Carlos Prestes. Uma resenha dizia que o livro servia "de advertência aos que se deixam envolver, na fase presente, pelos 'encantos' das fantasias ardilosas", se referindo ao fato de que Barata havia rompido com o PCB por ter chegado à conclusão de que ele não era o instrumento capaz de levar liberdade e justiça social ao povo. ${ }^{22}$

Essa leitura da obra tem significado especial se lembrarmos que naquele momento, início dos anos 1960, movimentos campesinos, sindicais e estudantis faziam com que a esquerda brasileira se renovasse e vivesse um momento de efervescência política. Dias depois, no mesmo jornal, o escritor Carlos Heitor Cony se juntava ao coro que concordava que a obra mostrava o que de pior haveria no Partido Comunista do Brasil e dizia que "os não comunistas devem lêlo, a fim de aprender o idealismo, o sacrifício e o heroísmo que fazem o dia-a-dia de um revolucionário e de um comunista sincero" mas que também "os comunistas devem nele aprender outras coisas, por exemplo, que para um comunista virar fascista basta penas - e às vezes - entrar para este mostrengo ideológico, político e social que é o PCB”. Dizia também que os fatos narrados não transformavam "o livro em um grande livro em si" mas transformavam o autor em "um homem digno de nossa admiração e respeito - e cuja luta, agora obscurecida pelas paixões, pela burrice e pelo carreirismo de muitos - um dia encontrará na História o lugar que lhe é devido", ${ }^{23}$

Em contraponto, o livro também recebeu críticas negativas. Antonio Callado havia publicado dias antes de Cony uma resenha onde afirmava ser o livro “fanfarrão mas simpático, é de um amadorismo literário que chega às raias do incrível”. Para provar sua perspectiva, apontava para determinados trechos como a passagem em que o autor reproduz um longo diálogo em castelhano que ouviu em Madrid ou o trecho que reconstitui o levante de 1935, que segundo Callado "há bom-humor carioca, bom-mocismo brasileiro e o quadro geral de um país brincando de revolução". E, apesar de se colocar a favor de Agildo Barata, defendendo que sua tese central é provar que não houve nenhuma covardia no

\footnotetext{
22 "Vida Cultural", Correio da Manhã, 22 de julho de 1962; "Notícias", Diário de Notícias, 10 de novembro de 1962; "Retrato de Prestes na prisão", Jornal do Brasil, 27 de maio de 1962; "Agildo Barata vai contar a história", Diário de Notícias, 27 de outubro de 1961.

23 "Livros novos", Correio da Manhã, 2 de novembro de 1962; "Da arte de falar mal: Eneida e Agildo", Correio da Manhã, 20 de novembro de 1962.
} 
levante do $3^{\circ}$ Regimento de Infantaria da Praia Vermelha e acreditar que o autor não assassinou ninguém, como não se conseguiu provar, Callado afirmava que "o horrível, o grotesco é a gratuidade do episódio [de 1935], a irresponsabilidade com que foi levado a cabo, sua total impossibilidade de êxito", colocando-se então contra o movimento comunista fracassado. ${ }^{24}$

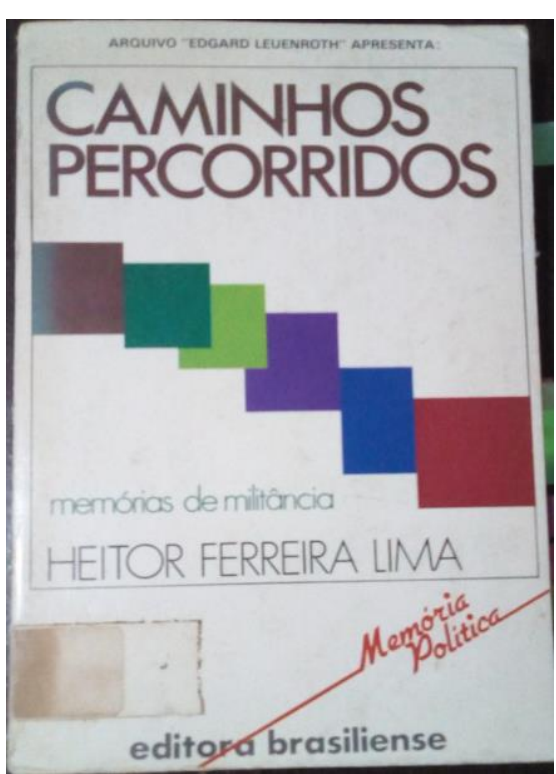

Com prefácio de Paulo Sérgio Pinheiro ${ }^{25}$, em que este afirma ser esta uma obra que dispensa texto de apresentação, mas que assim mesmo o escreve "como um agradecimento pela publicação dessas memórias tão esperadas", o quinto livro presente em nosso corpus documental tem uma capa simples e é intitulado Caminhos Percorridos - memórias de militância, de Heitor Ferreira Lima. Para Pinheiro, que não poupa elogios, um dos grandes méritos do livro estaria em ser uma biografia na qual os homens e os fatos em torno da vida biografada irromperiam numa variedade de dimensões: "Caminhos Percorridos faz uma só trama da trajetória do militante e a história observada. A autobiografia é pretexto para uma análise do Partido Comunista do Brasil, o PCB, desde sua fundação até os anos 1940, na cena política e na sociedade brasileira. " 26

\footnotetext{
24 “A bagunça da Revolução Brasileira”, de Antonio Callado, Correio da Manhã, 8 de dezembro de 1962.

25 Paulo Sérgio Pinheiro foi professor titular de ciência política da Universidade de São Paulo e membro da Comissão Nacional da Verdade. Desempenha desde 1995 várias funções na ONU, sendo atualmente presidente da Comissão Internacional de Investigação para a Síria.

26 LIMA, Heitor Ferreira. Caminhos percorridos (memórias de militância). São Paulo: editora Brasiliense, AEL, 1982, p. 7.
} 
E mais:

“O memorialista não tem o monopólio da palavra e da versão, todos falam, diferentes versões são apresentadas. [...] Não são memórias somente de ação, discussão ideológica, confronto de doutrinas. [...] São observações muito finas do tempo do memorialista, numa narrativa de grande simplicidade com elegância, de precisão com despojamento. "27

Segundo resenha publicada no Jornal do Brasil, "Caminhos Percorridos é um dos mais sóbrios livros de memórias políticas entre os muitos que apareceram nos últimos anos" e "apesar da modéstia, o autor contribui com muitas informações novas sobre o tema", sendo o livro comparado no mesmo artigo em razão e importância com as obras Partido Comunista Brasileiro: conflito e integração, de Ronald E. Chilcote e $O P C B$, de Edgard Carone. ${ }^{28}$ Já a resenha do contista e cronista Rubem Braga mostra outra perspectiva quando afirma que "de minha parte, apenas digo que a memória dele falhou, pois não duvido de sua boafé. Heitor, comunista ou, como se tornou depois, economista ligado aos meios industriais de S. Paulo, é um homem de bem. [...] e seu livro é interessantíssimo". ${ }^{29}$

Nascido em Corumbá, Mato Grosso do Sul em 1905 e falecido em São Paulo em 1989, Heitor Ferreira Lima é conhecido por ter sido sindicalista, jornalista, militante desde os princípios do $\mathrm{PCB}$ e escritor dedicado à reflexão da história econômica e industrial brasileira. Seu livro de memórias se desenvolve em quatro blocos de capítulos, nos quais dividiu e organizou a sua vida em quatro fases, todas de acordo com sua vida de militância. A primeira fase, assim como o primeiro bloco de capítulos, tem início em 1922, com a chegada do autor ao Rio de Janeiro no mesmo ano que o PCB era fundado, seu contato com as ideias socialistas e o primeiro momento de militância no Partido e no Sindicato dos Alfaiates.

O segundo e terceiro blocos, respectivamente "Três anos na União Soviética" e "Anos duros de combates", marcam as fases da vida do autor em que ele conta sobre a experiência que teve ao estudar na Escola Leninista de Moscou, as relações entre a Internacional Comunista e o PCB, sua participação nas

\footnotetext{
${ }^{27}$ LIMA, op. Cit., p. 8.

28 "PCB, divisões e oscilações", Jornal do Brasil, 18 de julho de 1982.

29 "Livro de antigo comunista", Revista Nacional/Jornal do Commercio, 12 a 18 de setembro de 1982.
} 
comemorações do aniversário de dez anos da Revolução de Outubro e no VI Congresso da Internacional Comunista, sua volta ao Brasil e seu papel na reorganização do PCB segundo as diretivas da União Soviética, as lutas internas do Partido e os episódios de prisão e deportação que sofre nas décadas de 1930 e 1940.

O quarto e último bloco de capítulos compreende o período após a sua libertação da prisão, em 1942, seu afastamento da militância e do Partido e início da sua atuação como jornalista e analista econômico da FIESP, resultando na produção dos livros Evolução Industrial de São Paulo (1954), Formação Industrial do Brasil (1961) e História Político-Econômica e Industrial (1970). Todos os blocos terminam com uma conclusão, em que o autor faz um balanço dos acontecimentos narrados e de sua trajetória de vida naquela determinada fase. A autobiografia de Ferreira Lima conta também com um texto de "Justificativa", em que o autor afirma que apesar de não ter realizado "qualquer obra de extraordinária importância", presenciou e participou, porém, de "acontecimentos sobre os quais até hoje não houve divulgação". Afirma ter sido "por isso [que] resolvi escrever essas páginas despretensiosas, como forma de depoimento pessoal, que poderão, quem sabe, ajudar as gerações futuras a conhecer e julgar aqueles fatos", atribuindo então aos futuros leitores a responsabilidade interpretar os fatos que vivenciou.

Dessa forma, a citação "Mas evocar o passado para nós é pensar no futuro", retirada da Autobiografia Precoce de Eugênio Evtuchenko e utilizada como epígrafe do livro, nos serve como indício do tom que a obra vai ter. O autor, ao mesclar a narrativa de sua vida com acontecimentos históricos intrínsecos à sua trajetória, acaba por desenvolver toda uma autocrítica à sua militância, ao PCB e à esquerda brasileira dos anos 1930 e 1940, além de personagens da esquerda latino-americana e suas relações com a Internacional Comunista. Tanto é que o autor justifica:

"Parece-me assim justificada a narração que vou fazer aqui, não propriamente da minha vida que nada tem de especial, mas desses fatos e episódios em que tomei parte ou que lhe dizem respeito muito de perto. "30

${ }^{30}$ LIMA, op. cit., p. 13. 
A edição aqui analisada terminou de ser escrita pelo autor em 1981, sendo publicada no ano seguinte pela editora Brasiliense, fundada por Caio Prado Júnior, Monteiro Lobato e Arthur Neves em 1943 e recebeu também o selo do Arquivo de História Social Edgard Leuenroth (AEL), e embora hoje não seja mais encontrada em catálogo, a obra foi provavelmente fruto de uma parceria entre essas duas instituições. $^{31}$

Neste capítulo, buscamos realizar uma análise inicial e mais geral das obras que compõem o corpus documental. Esta consistiu em fazer uma apresentação geral do formato e do conteúdo, isto é, mostrar como cada autor estruturou as suas memórias em uma narrativa de vida, resumindo e relacionando com a sua biografia. Mas também buscando compreender as razões que afirmam ter para escrever, colocando em relação com os respectivos contextos de escrita e publicação das primeiras edições.

Para alcançar tal objetivo, fizemos o esforço de buscar na imprensa de época os indícios de como ocorreu a recepção das obras em seu momento de publicação e de compreender, principalmente, os textos de apresentação, prólogos e prefácios presentes nas publicações, que nos dão preciosos indícios sobre as intenções biográficas dos autores pois anunciam e reafirmam o caráter principal que cada obra vai tomar.

Por exemplo, Nos Subterrâneos do Estado Novo busca ser uma obra de denúncia sobre a perseguição política perpetrada pelas forças do regime Vargas, mas, para tanto, Herondino Pereira Pinto utiliza a narrativa da experiência vivida por ele mesmo. Já Leôncio Basbaum busca afirmar seu livro de memórias como uma obra intelectual, não um manifesto político, mas as interpretações que podemos encontrar pela imprensa, inclusive em resenha de seu próprio filho, vão na direção de ver a obra como importante contribuição para a história do PCB. O que é algo que Heitor Ferreira Lima enfatiza em suas memórias, ao afirmar que importa mais os acontecimentos que presenciou, isto é, Os Caminhos Percorridos, e menos o que fez, pois não teria realizado obras de verdadeira importância.

\footnotetext{
${ }^{31}$ Criado na UNICAMP em 1973 a partir da doação de acervos documentais de vários intelectuais, o AEL leva o nome do militante e jornalista anarquista Edgar Leuenroth (1881-1968), cujo acervo de 1030 periódicos e 3500 livros foi a doação fundadora do Arquivo. https://www.ael.ifch.unicamp.br/acervo
} 
Por sua vez, Gregório Bezerra narra suas Memórias como uma história épica, como se desde a infância pobre no Agreste pernambucano ele já estivesse destinado por inclinação à militância e, portanto, para o heroísmo da luta política. Enquanto isso, Agildo Barata definiu a si mesmo como um revolucionário, identidade que atribui como desenvolvimento da característica da rebeldia que lhe foi incutida por conta da morte da mãe, ainda quando criança, e que teria marcado toda a sua vida, levando-o viver tudo o que viveu.

O objetivo, assim, foi o de dar ao leitor um panorama inicial sobre o que tratam os livros de memórias antes de entrarmos na análise mais aprofundada do nosso recorte específico das trajetórias de vida dos autores - a saber, suas trajetórias e experiências de prisão durante as décadas de 1930 e 1940. 


\section{3 \\ Trajetórias de encarceramento}

As obras memorialísticas divergem quanto à forma, estilo e intenções de cada autor, mas convergem ao dar a ver as suas perspectivas sobre a experiência de prisão política durante as décadas de 1930 e 1940 no Brasil, sendo importantes fontes para compreender a vida social das prisões pelas quais seus autores passaram. Por conta disso, neste capítulo, analisamos as trajetórias traçadas por estes militantes ao se tornarem presos políticos durante o Governo Vargas. Há um traço comum nessas trajetórias: após a prisão efetuada, o indivíduo era encarcerado na Casa de Detenção da capital do estado em que se encontrava. Ali, ele permanecia por um tempo, enquanto estivesse à disposição da justiça ou da polícia. Havia Casas de Detenção no Rio, em São Paulo, em Recife, em Fortaleza. Dali, eram deslocados por via marítima, em navio, para alguma das ilhas prisionais. Há também o caso específico de alguns presos que foram transferidos da prisão insular de Fernando de Noronha, em 1942, para a Colônia Correcional de Dois Rios, em Ilha Grande, litoral do Rio de Janeiro, por ocasião da transformação da ilha do litoral pernambucano em Base Militar.

Tratamos aqui, então, sobre a trajetória de encarceramento entre cárceres continentais e ilhas-prisões, além dos deslocamentos efetuados em navios, uma extensão do cárcere em movimento. É necessário dizer que essas trajetórias de encarceramento se constituem em um recorte que fizemos na trajetória geral e narrativa da vida de cada autor. Dessa forma, este capítulo se divide em compreender os diferentes contextos em que os autores foram presos e analisar o que contam sobre a experiência prisional nas Casas de Detenção, nas ilhas prisionais e nos navios. Nossa intenção, portanto, é a de trazer à tona sob as suas perspectivas acerca da vida social que encontraram nos cárceres enquanto presos políticos.

\subsection{Atos de prisão}

Os autores das obras que compõem nosso corpus documental têm em comum, entre outras coisas, o fato de terem passado pela experiência de prisão 
política. Porém, essa experiência se deu em momentos diferentes do longo primeiro governo de Getúlio Vargas e por conta de contextos diferentes que o processo histórico que caracteriza esses anos assumiu. O efeito resultante dessas prisões foi o mesmo: atribuir aos militantes o estatuto de preso político, ao criminalizar a prática da militância. Por isso, o momento de prisão é sempre importante nas narrativas - razão pela qual se torna necessário compreendê-lo.

Heitor Ferreira Lima era secretário do PCB quando, em meados do ano de 1931, foi enviado para o Nordeste, com o objetivo de reforçar o trabalho do Partido nos estados da região. $\mathrm{O}$ autor explica que sua transferência se deu por decisão de uma militante que viera ao Rio como instrutora e com quem acabou tendo um desentendimento. $\mathrm{O}$ autor se refere a essa mulher como Inês, esposa de Augusto Guralski, conhecido na época como Rústico, que trabalhava como secretário do Bureau Sul-Americano e a quem qualifica como "sectária e autoritária como seu marido" .

Assim como boa parte dos sujeitos que mantinham militância no movimento comunista e anarquista, Ferreira Lima tinha experiência prévia quanto à mobilidade e deslocamento. Ele mesmo havia acabado de chegar da União Soviética, onde frequentou a Escola Leninista por três anos, e assumido o cargo de Secretário Geral do PCB quando foi enviado ao Nordeste. Era bastante comum aos militantes comunistas e anarquistas que tivessem que se deslocar com frequência por razões de propaganda e difusão política ou por conta de perseguições e repressão estatal. ${ }^{2}$ Sua viagem pelo Nordeste começou por Recife, mas também passou por Natal e Fortaleza, onde foi preso quando tentava seguir para Teresina na boleia de um caminhão em algum momento do segundo semestre do ano de 1932. Foi levado para a delegacia local e depois para a Casa de Detenção de Fortaleza, onde teve início sua trajetória de prisão. ${ }^{3}$

\footnotetext{
${ }^{1}$ LIMA, Heitor Ferreira. Caminhos percorridos (memórias de militância). São Paulo: editora Brasiliense, AEL, 1982, p. 146, 147.

2 As biografias de militantes comunistas e anarquistas mostram que esses sujeitos estavam familiarizados com a sempre iminente possibilidade de ter que se deslocar. Como exemplo, podemos citar a biografia de Oreste Ristori, escrita pelo historiador Carlo Romani. Cf. ROMANI, C. Oreste Ristori. Uma aventura anarquista. São Paulo: Annablume, 2002.

${ }^{3}$ LIMA, op. cit., p. 149-157.
} 
Leôncio Basbaum, por sua vez, foi preso várias vezes, todas por conta de sua militância política. A primeira prisão foi efetuada em abril de 1931, quando estava envolvido com os preparativos do comício que o PCB faria no dia do trabalhador daquele ano no Rio de Janeiro. Naquela ocasião, ele foi levado para a Polícia Central da rua da Relação e em seguida para a Casa de Detenção. Depois, o autor ainda "peregrinou" por alguns cárceres durante cerca de três meses a caminho do Uruguai, para onde foi deportado, mas onde passou pouco tempo e em liberdade. Em agosto daquele mesmo ano, Basbaum já desembarcava em Santos, com um passaporte falso, indo direto para São Paulo e à serviço do Partido. $^{4}$

Em São Paulo, meses após seu retorno, ocorreu a sua segunda prisão. $\mathrm{Na}$ ocasião, diversas categorias profissionais estavam em greve, em exigência por melhores salários e legislação trabalhista, mas também reivindicando que Getúlio Vargas realizasse a Constituinte. O PCB, na ânsia de fazer parte do movimento, convocou uma reunião do seu Comitê de Greve no sindicato dos gráficos, localizado próximo à Praça da Sé. Como membro do Bureau Político, Basbaum era encarregado de fazer um discurso neste evento, tendo o objetivo de insuflar os grevistas a expandir os protestos e reafirmar o apoio do PCB, mas mal teve chance de começar a falar quando policiais à paisana invadiram o salão e o levaram preso, junto com outros militantes e sindicalistas, para a delegacia da Rua dos Gusmões. ${ }^{5}$

Ali, fizeram greve de fome, exigindo tratamento de presos políticos e por fim foram transferidos para o chamado Presídio da Liberdade, que não lhe pareceu ser bem um presídio, mas uma casa na qual presos políticos eram mantidos, mas afirma que este lugar tinha condições de higiene e alimentação melhores que as celas da delegacia que estivera antes. ${ }^{6}$ Os presos políticos que encontrou ali, relata, eram quase todos operários estrangeiros, detidos por conta das greves e

\footnotetext{
${ }^{4}$ BASBAUM, Leôncio. Uma vida em seis tempos (memórias). São Paulo: Alfa-Ômega, 1978, p. $98-111$.

${ }^{5}$ Ibid, p. 123, 124.

${ }^{6} O$ Correio de S. Paulo afirma que o Presídio da Liberdade se situava à rua da Liberdade $\mathrm{n}^{\circ} 159 \mathrm{e}$ informa que ali também funcionava a sede da Guarda Noturna. Já o periódico A Gazeta informa que a prisão da Liberdade, assim como a da Immigração, é referida como presídios políticos e teriam sido fechados "por inúteis" e os presos políticos teriam sido postos em liberdade pela chefe de polícia. Cf. O Correio de São Paulo, 16 de junho de 1934; A Gazeta, 25 de março de 1933.
} 
também se encontravam em greve de fome por conta de uma ameaça de serem enviados para o presídio da Ilha Grande. ${ }^{7}$

A transferência que esses presos temiam teria se dado após três dias de greve de fome - e apesar dela. Os presos foram despertados no meio da noite, colocados em carros, levados para a estação de trem e embarcados em vagões de carga. Chegando ao Rio, foram levados em tintureiros da polícia da Central do Brasil para a Casa de Detenção na Rua Frei Caneca, onde finalmente suspenderam a greve que não havia alcançado seu objetivo. Em pouco tempo, seriam transferidos para a Colônia Correcional de Dois Rios. ${ }^{8}$

No capítulo anterior, vimos que Agildo Barata e Gregório Bezerra foram presos em 1935, por conta de suas atuações em posições de liderança nos levantes ocorridos em quartéis do Rio de Janeiro e Recife, sob comando da ANL. Ambos também são os autores que passam mais tempo na prisão, pois são presos em 1935 e libertos apenas com a Lei de Anistia de 1945. Barata cumpria uma punição disciplinar no $3^{\circ}$ Regimento de Infantaria do Exército, situado na Praia Vermelha, por conta de sua atuação na ANL na cidade de São Leopoldo, Rio Grande do Sul, quando da ocasião dos levantes comunistas de 1935. A ele, coube um papel de liderança na sublevação do quartel situado no bairro carioca da Urca. Sobre os quase dez anos de cárcere que sofreu, afirma ser impossível dizer quanto tempo passou em cada prisão, ou a ordem exata de sua trajetória, pois não lhe "passou pela cabeça" escrever ou registrar notas sobre "tão negros e odiosos fatos". Mas ao relatar o episódio do levante no $3^{\circ} \mathrm{RI}$, conta que após as horas de resistência contra as tropas do governo, os revolucionários capitularam e "saíram escoltados para a Av. Pasteur onde uma fila de ônibus da Light, solicitamente colocados à disposição do Governo" aguardava; dali seriam transportados para a Casa de Detenção da Rua Frei Caneca. ${ }^{9}$

Segundo Gregório Bezerra, para cumprir seu papel no levante de Recife, ele "deveria assaltar o quartel-general, a Secretaria de Segurança, o Palácio do Governo, a Central Telefônica e ocupar os pontos-chave da cidade". Porém, ele

\footnotetext{
${ }^{7}$ BASBAUM, op. cit, p. 125, 126.

${ }^{8}$ Ibid, p. 127.

${ }^{9}$ BARATA, Agildo. Vida de um revolucionário (memórias). São Paulo: Alfa-Ômega, 1978, p. 300.
} 
acabou por deflagrar o levante praticamente sozinho pois a ordem do comando revolucionário era para que fosse executado o plano em um momento em que os quartéis se encontravam vazios e os operários que teriam se comprometido com o PCB nunca apareceram. Assim, buscando cumprir as ordens e levar o plano revolucionário adiante, o autor acabou entrando numa troca de tiros com dois oficiais que identifica como tenente Agnaldo e o sargento José Alexandre Vieira, sendo alvejado pelas costas por este último, recebendo um tiro na coxa. Bezerra conta com uma riqueza de detalhes a luta corporal que se seguiu com esse sargento, mas da qual teria conseguido se livrar e tomar o CPOR. Mais tarde, ao tentar buscar em outros quartéis elementos que aderissem ao levante, acabou sendo levado ao pronto-socorro, onde teria recebido voz de prisão do tal tenente Agnaldo. Por ser sargento, Gregório foi levado preso ao quartel general do Exército, e dali para a Secretaria de Segurança Pública onde deveria ser interrogado. Alegando passar mal do ferimento na coxa, ele se negou a dar o depoimento e foi transferido para a enfermaria da Casa de Detenção de Recife, onde afirma ter sido mantido incomunicável até 1936, quando passou a sofrer interrogatórios sob tortura.

Em Nos Subterrâneos do Estado Novo, Herondino Pereira Pinto não relata sobre como ocorreu sua prisão, porém o periódico A Manhã conta que o autor foi preso quando participava de uma assembleia da Confederação Syndical Unitária do Brasil na sede da União dos Trabalhadores do Livro e do Jornal. Ele era delegado do sindicato dos ferroviários e trabalhava como escrevente; a reunião discutia o movimento para reivindicar um "aumento geral de salários" e contava com trabalhadores de várias áreas quando foi interrompida pela chegada de quatro tintureiros e inúmeros soldados da polícia, que depredaram a sede do sindicato, espancaram várias pessoas presentes e levaram presos cerca de 80 trabalhadores para a Polícia Central, entre eles Pereira Pinto. ${ }^{10}$

Mais tarde, foi recolhido à Casa de Detenção e posteriormente transferido para a Ilha Grande, sendo posto em liberdade em junho de 1937, em ocasião da

10 "Violentamente dissolvida a assembleia da Confederação Syndical Unitária do Brasil", A Manhã, 4 de agosto de 1935; "Mais detalhes do estúpido attentado de sabbado, à noite, na séde dos graphicos", A Manhã, 6 de agosto de 1935. 
"Macedada". ${ }^{11}$ Voltou a ser preso em agosto, sendo libertado meses depois, no ano seguinte, segundo o próprio autor nos relata. ${ }^{12}$

\subsection{Nas Casas de Detenção}

Após a prisão, as Casas de Detenção do Rio de Janeiro, Pernambuco, São Paulo e Ceará foram o destino carcerário dos nossos presos, enquanto aguardavam a transferência para uma das ilhas prisionais. Estes estabelecimentos datam do século XIX, momento em que as prisões estavam sendo pensadas como parte do projeto civilizador, pois substituiriam as penas de castigos corporais e públicos relacionadas à antiga ordem colonial. Construída em 1856, a partir de um andar térreo da Casa de Correção, a Casa de Detenção do Distrito Federal tinha caráter provisório que foi com o tempo se tornando definitivo. Ambas as Casas eram situadas no mesmo endereço da rua Frei Caneca, tendo a prisão para correcionais sido criada em 1834, dentro do movimento transnacional de reforma e modernização das prisões em voga no século XIX, e inspirada no modelo da prisão norte-americana de Auburn, porém apenas parte do projeto foi construído antes que o orçamento se esgotasse.

A Casa de Correção da Corte foi a primeira, mas logo em seguida foram realizadas as construções das principais Casas de Correção e Detenção do Império e, a partir do que dizia o Código Criminal de 1830, tais instituições se tornaram lugar para aplicação principalmente de penas de prisão com trabalho, que tinham por objetivo regenerar e corrigir moralmente o criminoso e devolvê-lo ao convívio social como um indivíduo disciplinado e acostumado com uma rotina de trabalho. Segundo Amy Chazkel, "os nomes destas duas instituições resumem seus respectivos propósitos: uma desejava corrigir e a outra simplesmente deter" os presos. ${ }^{13}$ Assim, a Casa de Detenção - e não apenas a da capital da República -

\footnotetext{
${ }^{11}$ A Macedada foi como ficou conhecida a decisão do ministro da Justiça José Carlos de Macedo Soares, após visitar as Casas de Detenção e Correção do Distrito Federal, de libertar 308 presos políticos. "A visita do sr. ministro da Justiça às Casas de Detenção e Correção", Jornal do Brasil, 8 de junho de 1937.

${ }^{12}$ PINTO, Heron Pereira. Nos subterrâneos do Estado Novo. Rio de Janeiro: Editora Germinal, 1950 , p. 14.

${ }^{13}$ CHAZKEL, Amy. Uma perigosíssima lição: A Casa de Detenção do Rio de Janeiro na Primeira República. Em: MAIA, C., NETO, F.S., COSTA, M., BRETAS, M. História das Prisões no Brasil. Rio de Janeiro, 2009, vol. 2, p. 10.
} 
recebia os presos que estivessem detidos para averiguação ou que esperavam julgamento. Nas primeiras décadas da República, essas instituições passaram também a receber presos políticos provenientes da repressão aos movimentos anarquista e comunista e das inúmeras greves que começaram a eclodir a partir da década de 1910. A década de 1930 vê crescer a quantidade de prisões políticas que já vinham ocorrendo desde o início do século, mas que agora se tornam recorrentes e ganham uma legislação própria.

Preso político fruto desse movimento, Agildo Barata conta que os revolucionários do $3^{\circ}$ Regimento de Infantaria, ao ter o levante fracassado, foram logo levados em ônibus da Light para a Casa de Detenção do Rio de Janeiro. O autor afirma que "este presídio era destinado a detentos da justiça comum e, assim, desde os primeiros dias de nossa prisão, a ditadura getulista evidenciava seus propósitos de relegar ao mais absoluto desprezo, qualquer respeito à nossa situação de presos políticos", demonstrando o descontentamento por ter ido parar naquela prisão, estigmatizada desde os primeiros anos de sua fundação, ainda no Império. ${ }^{14}$

Ao contar sobre sua experiência de passagem pela Casa de Detenção, Barata diz ter conhecido ali o famoso malandro carioca chamado de Meia-Noite ${ }^{15}$, que teria se apresentado como um admirador e que inclusive teria exigido do Diretor da prisão que o preso político fosse transferido para uma cela melhor quando ele se encontrava em uma cela solitária, visto que ele seria alguém tão poderoso dentro da Detenção que desempenharia um papel de "superdiretor" da prisão. ${ }^{16}$ Heron Pereira Pinto também menciona a figura de Meia-Noite e aponta que seu cubículo era "um verdadeiro cassino", ${ }^{17}$ indicando a ocorrência de jogos na Casa de Detenção. Barata afirma ainda que o diretor da Casa de Detenção não só recebia dinheiro do malandro Meia-Noite, mas também teria outras formas

\footnotetext{
${ }^{14}$ BARATA, op. cit., p. 303.

${ }^{15}$ Uma nota no Jornal do Brasil poucos anos depois afirma que o malandro Meia-Noite morreu "justamente quando ele ia ensaiando os primeiros passos para a regeneração". "Meia Noite", Jornal do Brasil, 2 de setembro de 1937.

${ }^{16}$ Ibid, p. 309.

17 PINTO, op. cit., p. 28.
} 
corruptas de ganhar dinheiro, como o esquema de servir o almoço dos presos em um horário tardio de forma que pudesse cancelar o serviço do jantar. ${ }^{18}$

Barata relata ainda a ocasião em que uma companheira presa, que identifica como "a jornalista e escritora Eneida" foi acometida de uma febre alta e os presos políticos então se organizaram e exigiram que o presídio providenciasse um médico. Diante da reivindicação negada, os presos políticos enfrentaram os guardas e exigiram uma audiência:

"Forçamos a saída do pavilhão onde nos encontrávamos e fomos, mesmo empurrando os guardas que procuravam deter-nos, até o gabinete do diretor onde este, acovardado, se escondeu num W.C. privativo do diretor. Encontramos em seu lugar, um tal Pestana, vice-diretor, a quem obrigamos a telefonar, no momento, chamando um médico e só nos retiramos depois do médico vir entrando no presídio..."19

Por conta do episódio, Barata e outros presos foram recolhidos à solitária.

Todos os outros presos também registraram passagem pela Casa de Detenção do Rio de Janeiro. Leôncio Basbaum chegou ali após transferência efetuada em vagões de trem de carga, vindo da Prisão da Liberdade. Conta que, ao chegar ao Rio, os presos decidiram suspender a greve de fome que faziam há alguns dias desde São Paulo e puderam saborear o café com pão que lhes foi servido, o que lhes "trouxe alma nova e o coração alegre". Porém, não demorou muito para que logo começassem a se organizar pois como militantes que eram, não deixavam a militância política de fora de suas vidas em nenhum momento. A prisão era convertida então em mais um espaço para socialização da militância:

"Passado esse momento de reconforto, tratamos imediatamente de eleger uma nova direção do 'coletivo', composto de cinco pessoas, e a distribuir o tempo, marcando horas de discussão e estudos teóricos para os que quisessem: marxismo, situação brasileira, União Soviética, socialismo etc., eram temas de estudo e discussão. Análise da atuação do Partido, não era conveniente, pelo menos no momento. "20

O "coletivo", maneira como os presos políticos de esquerda se entendiam como um conjunto organizado dentro da prisão, também preparou uma lista de reivindicações que queriam pleitear junto ao diretor da Casa de Detenção, que

\footnotetext{
${ }^{18}$ BARATA, op.cit., p. 314.

${ }^{19}$ Ibid., p. 316.

${ }^{20}$ BASBAUM, op. cit., p. 127.
} 
incluíam passeio ao ar livre, fornecimento de leite para os mais velhos e enfermos, talheres e colchões. A reivindicação do leite aos mais velhos foi concedida e ao coletivo foi dado o direito de mandar comprar cigarros e forneceram-se alguns colchões, que foram devolvidos por estarem infestados de percevejos.

Basbaum relata que, para passar o tempo, os presos jogavam xadrez cujas peças eram feitas por eles mesmos com miolo de pão e cujo tabuleiro era um pedaço de cartolina riscado. Mesmo assim, "ao fim de dois meses de prisão, na mesma cela, sem ver a luz do sol, sem ter o que fazer, estávamos, na verdade, todos enervados". ${ }^{21}$ Esse estado de exasperação, segundo conta, foi se tornando mais intenso até que um dia acabou por se tornar um movimento que os guardas e a direção do presídio provavelmente entenderam como greve, revolta ou motim. ${ }^{22}$ Os presos políticos, após terem a reivindicação de passar um tempo ao ar livre negada, teriam começado "a fazer barulho de marmita nas grades, acompanhado de gritos e cantos, do que os detentos se aproveitavam para fazer barulho também, o que transformou nossa galeria em um inferno de barulho". Como castigo para o protesto dos presos, o presídio suprimiu o leite para os idosos e enfermos e suspendeu o direito de visitas, que haviam conquistado recentemente. O movimento dos presos não parou por aí. Tendo o pedido de conversar com o diretor da Casa de Detenção negado, vários presos teriam se lançado às tábuas que pregavam as janelas do presídio e as arrancado com as próprias mãos.

$\mathrm{O}$ autor relata que:

"Logo compareceu a polícia militar, de armas embaladas, apontadas contra nós, com ameaças de fuzilamento sumário. Mas não nos intimidamos e começamos a cantar a Internacional e o hino nacional. Vendo que não nos intimidávamos, apareceu um recado do Diretor dizendo que nomeássemos uma comissão para falar com ele. Foram indicados Grazzini, Morena e eu." 23

Apenas a Basbaum foi concedido o direito de conversar com o Diretor e, por isso, ele conta ter sido recebido "pelo Diretor em sua sala, devidamente guardada por dentro e por fora por soldados de armas embaladas, como se eu

\footnotetext{
${ }^{21}$ BASBAUM, op. cit., p. 128.

${ }^{22}$ Greves, motins ou revoltas coletivas de presos como a descrita por Basbaum eram recorrentes nas Casas de Detenção e Correção desde o fim do século XIX e acompanhadas de perto pelos jornais, tal como analisa Marilene Antunes Sant'anna.

${ }^{23}$ Ibid., p. 129.
} 
fosse capaz, mesmo desarmado, de tomar o poder, ou mesmo agredi-lo". Dessa conversa, Basbaum diz apenas ter recebido em troca alguns xingamentos e a palavra do Diretor de que falaria com os seus superiores sobre as reivindicações. Apesar desse episódio ter sido seguido da estadia na solitária da Casa de Detenção, nos faz questionar se a margem para negociação seria possível se Basbaum fosse um preso por um crime dito comum ou se o movimento teria sido simplesmente resolvido com repressão pura e violenta.

O porão do presídio, descrito pelo autor como uma área "quase totalmente escura, alumiada por uma pequena lâmpada presa ao teto, que de quase nada servia. [...] A luz mais forte vinha de três pequenas aberturas de mais ou menos dez por dez centímetros, quase no teto, de uns dois metros de altura". Basbaum passou cerca de um mês em uma das cinco "celas de castigo" que "tinham mais ou menos um metro e oitenta de comprimento por um de largura; toda em cimento, fazia um frio e uma umidade difícil de suportar". ${ }^{24}$ Depois, ao retornar à cela onde se encontravam os presos políticos, deparou-se com um clima que define como "o pior possível", "pois estavam quase todos brigados entre si, formando pequenos grupos. Todos temiam a transferência para a Ilha Grande, coisa que lhes parecia certa, conforme haviam sido avisados por um preso. " A informação do preso não identificado procedia; eles seriam transferidos para a Ilha Grande dias depois. ${ }^{25}$

Já Pereira Pinto, que se refere à Casa de Detenção do Distrito Federal como "o túmulo dos vivos", diz que o que se passava ali era "indiscutivelmente vergonhoso e incrível" pois "os cubículos, imundos e antiquados, de 5x5, alojam vinte e trinta detentos, numa horripilante promiscuidade" e que "as cenas mais degradantes ganham aspecto de naturalidade sem que a administração tome a menor providência para o acautelamento da vida e da moral dos detentos". Reclama também, Pinto, sobre a superlotação da instituição, uma temática constantemente presente na imprensa daqueles anos, junto com as notícias sobre motins de $\operatorname{presos}^{26}$ : “A Casa de Detenção é, no máximo, para 600 detentos. Entretanto, a polícia política enviou para lá mais de 800 cidadãos". ${ }^{27}$

\footnotetext{
${ }^{24}$ BASBAUM, op. cit., p. 130.

25 Ibid., p. 130, 131.

${ }^{26}$ SANT'ANNA, Marilene Antunes. A imaginação do castigo: discursos e práticas sobre a Casa de Correção do Rio de Janeiro. Tese de Doutorado. Rio de Janeiro: UFRJ.

${ }^{27}$ PINTO, op. cit., p. 25.
} 
Segundo conta, a estrutura era completamente precária pois os presos precisavam dormir "no cimento puro e gelado, a alimentação, deficiente e mal cheirosa, era fornecida de 24 em 24 horas" e continua o relato de protesto, fazendo inclusive menção à visita do ministro da Justiça, que logo em seguida realizaria a chamada Macedada e libertaria vários presos políticos:

"De início, há resistência contra a 'boia' mal cheirosa, gosmenta, repelente e de vários dias, visto que o organismo do cidadão ainda não consumiu de todo as últimas energias. Além de servidas em marmitas amassadas cujo estado de conservação por si só bastava para repugnar a menos exigente criatura, ainda o seu conteúdo, em poucas horas, ficava putrefato, como aconteceu com uma porção vista pelo Sr. Ministro da Justiça, Sr. José Carlos de Macedo Soares, quando de sua visita aos presídios desta Capital." 28

Heitor Ferreira Lima também esteve preso na Casa de Detenção da capital federal, mas por pouco tempo antes de ser enviado para a Colônia Correcional de Dois Rio. Porém, por ter sido preso em Fortaleza, experimentou o encarceramento na Casa de Detenção cearense - que por vezes é referida como Cadeia Pública ${ }^{29} \mathrm{e}$ foi construída entre 1851 e 1866 - antes de ser transferido para o Rio de Janeiro. Ali, relata ter sido encarcerado primeiro em uma cela do andar térreo, onde encontrava-se a galeria de presos comuns. Diferente dos outros autores que reclamam o fato de serem tratados como os presos por crimes ditos comuns, o autor não parece esboçar nenhuma reclamação. As impressões sobre os presos não políticos só aparecem a partir da narrativa sobre a transferência para a Ilha Grande, mas sobre esse tema, analisamos de forma mais clara no próximo capítulo.

Segundo o autor, em princípios de outubro, o despertaram à noite e lhe deram ordem de preparar suas coisas e o levaram para o porto, onde o colocaram em "um navio apinhado de "batalhões patrióticos"” que desta vez o levaria para o Rio de Janeiro. ${ }^{30}$ Chegando ao Rio de Janeiro, o autor afirma ter sido levado primeiro para a Polícia Central, na Rua da Relação, onde passou alguns dias antes

\footnotetext{
28 PINTO, op. cit., p. 28, 29.

${ }^{29}$ Cf. MARIZ, Silviana Fernandes. Oficina de Satanás: a Cadeia Pública de Fortaleza (18501889). Dissertação de mestrado, UFC, Fortaleza, 2004, 156 p.; FILHO, Porfírio de Lima. No tempo dos Látegos e dos Grilhões: memória sobre a Cadeia Pública de Fortaleza (1931). Fortaleza: Arquivo Público do Estado do Ceará, 2013.

${ }^{30}$ LIMA, op. cit., p. 160.
} 
de ser transferido para a Casa de Detenção. Na prisão da Rua Frei Caneca, foi posto em um cubículo onde já estavam alguns presos políticos. Entretanto a estadia de Heitor Ferreira Lima e dos presos políticos que ali encontrou não duraria muitos dias mais, pois logo eles seriam transferidos para a Colônia Correcional de Dois Rios, em Ilha Grande, litoral do Rio de Janeiro - onde encontraria mais alguns outros presos políticos, inclusive Leôncio Basbaum.

Quanto à Gregório Bezerra, por ter tido sua prisão efetuada em Recife, seu destino foi a Casa de Detenção que lá havia. O presídio era uma construção aprovada pela Assembleia Legislativa pernambucana ainda em 1848 e que teve as suas obras iniciadas apenas dois anos depois. Na época, sua criação urgia para que substituísse a Cadeia do Recife, que remetia ao período colonial e que não dava conta dos presos provenientes da violência e criminalidade crescente de uma grande cidade do Império do Brasil. A prisão havia sido criada para ser uma penitenciária modelo, que servisse para pôr fim às velhas práticas punitivas não mais condizentes com o objetivo de inserir o Brasil no rol das nações civilizadas, modernas e liberais. ${ }^{31}$

Diferente dos outros autores que não relatam ter sofrido tortura, Gregório Bezerra conta que, enquanto esteve na Casa de Detenção, foi retirado algumas vezes no meio da noite e levado à Secretaria de Segurança Pública de Recife, onde era interrogado sob tortura. Segundo o autor, em 1935

"só houve espancamentos nos atos de prisão, mas não houve tortura. Estas começaram, violenta e barbaramente, em fevereiro [de 1936], principalmente depois da prisão de Luiz Carlos Prestes, no Rio. " 32

Das sevícias desses episódios de tortura, Gregório afirma que sobreviveu apenas por conta da ajuda de um jovem estudante de medicina que fazia estágio na Casa de Detenção e tinha sido seu aluno no Tiro de Guerra 333. O rapaz teria lhe entregue remédios de forma clandestina, apesar do aviso da Secretaria de Segurança Pública de que não fosse prestado nenhum socorro médico à Bezerra.

\footnotetext{
${ }^{31}$ NETO, Flávio de Sá C.A. Da cadeia à Detenção: reforma prisional no Recife em meados do século XIX. Em: MAIA, C., NETO, F.S., COSTA, M., BRETAS, M. História das Prisões no Brasil. Rio de Janeiro, 2009, vol. 2, p. 75-109. MAIA, C. A Casa de Detenção do Recife: controle e conflitos (1855-1915). Em: MAIA, C., NETO, F.S., COSTA, M., BRETAS, M. História das Prisões no Brasil. Rio de Janeiro, 2009, vol. 2, p. 112 - 115

${ }^{32}$ BEZERRA, Gregório. Memórias. São Paulo: Boitempo editorial, 2011, p. 247.
} 
O autor conta sobre ter ficado amigo de um carcereiro que qualifica como um rapaz muito jovem e de boa aparência, mas que havia sido "intoxicado pela propaganda contra mim e contra os comunistas em geral, um verdadeiro cão de fila, dos mais perigosos que conheci na prisão. "Esse rapaz exerceria a tarefa de vigilância com extremo afinco:

"quando encontrava uma ponta de cigarro defronte de minha grade ou nas vizinhanças de minha cela, abria e esfarinhava o fumo para ver se havia algo escrito. Quando me levava ao banheiro, fazia-me esperá-lo à porta, distorcia o chuveiro, metia o dedo no interior do cano de água para ver se tinha algo escrito; levantava o ralo do esgoto do banheiro, arregaçava a manga da túnica e atolava a mão no esgoto. Feitas estas operações, mandava-me entrar e ficava esperando para levar-me de volta ao cubículo." 33

Gregório Bezerra demonstra neste trecho o quanto as autoridades prisionais estavam preocupadas com a militância que se fazia dentro da prisão, a ponto do guarda necessitar vasculhar inclusive o esgoto antes do preso político utilizar o banheiro. Apesar da ostensiva vigilância, Bezerra decide estabelecer um contato amistoso com o guarda; a aproximação se dá no dia em que o autor percebe o guarda andando nervosamente de um lado para outro e resolve lhe perguntar sobre o que o incomodava. Sabendo então que a razão do incômodo era o filho doente e da falta de dinheiro para levá-lo ao médico, Bezerra afirma ter entregue ao carcereiro os cinquenta mil-réis que tinha no bolso, ao que disse que não estava lhe dando o dinheiro, mas ao seu filho doente e ainda teria lhe indicado "um médico especialista em doença infantil, o dr. João Tavares". ${ }^{34}$ Daí, teria surgido uma amizade entre eles, resultando inclusive em conversas sobre o que era ser comunista, sugestões de leituras e na filiação do rapaz ao PCB. De guarda que perseguia e reprimia a militância dentro da Casa de Detenção, o rapaz teria sido convertido em militante.

Bezerra também conta sobre o sistema de comunicação entre as celas da Casa de Detenção que os presos políticos teriam desenvolvido, apesar da incomunicabilidade e vigilância às quais estavam submetidos. Ele explica:

\footnotetext{
${ }^{33}$ Ibid, p. 252.

${ }^{34}$ Sobre o dinheiro que Gregório possuía, o autor afirma que havia sido enviado por sua esposa de maneira bem peculiar - atado com barbante a uma pedra que foi arremessada da rua para dentro de sua cela, o dinheiro acompanhava um bilhete dando notícias de que sua família se encontrava bem.
} 
"Utilizávamos os dedos da mão para fazer as letras do alfabeto. Como as portas das celas eram fechadas, além das grades, com as portas de madeira, só podíamos nos comunicar quando um companheiro de uma cela subia à janela que ficava ao alto e transmitia os sinais para outro companheiro, também postado em sua janela. "35

Com a saúde precária por conta das torturas, Gregório não conseguia subir a janela de sua cela, mas nem por isso ficava por fora do sistema de comunicação. Ele afirma que "o cabo Siqueira, que estava numa cela ao lado da minha, foi encarregado de me transmitir as mensagens, o que fazia através da parede, usando código morse."

Segundo Bezerra, o sucesso desse sistema de comunicação estaria garantido pelo fato dos presos políticos utilizarem nomes de guerra. Porém, quando o cabo Siqueira foi solto, esqueceu em sua antiga cela um papel com a relação dos nomes de guerra e os nomes reais dos presos. $\mathrm{O}$ carcereiro Miranda, aquele a quem o autor afirma ter ajudado, teria achado o papel e lhe pedido que queimasse imediatamente - essa teria sido a primeira tarefa do carcereiro exanticomunista para o PCB, mas que só então Bezerra refere com um nome. Após esse episódio, a comunicação entre celas começou a ser feita apenas em código Morse.

Descoberta também essa forma de comunicação pouco tempo depois, seria substituída pelo que Bezerra se referiu por "merdafone". Era um sistema de comunicação que utilizava como meio os vasos sanitários, que tinham sua água esgotada, e através dele os presos transmitiam mensagens. Segundo Gregório, era um meio de comunicação "muito eficiente", porém tinha o inconveniente de que o esgoto da Casa de Detenção vazava para o Rio Capibaribe, fazendo com que subissem gases fortes quando era tempo de maré alta e causando intoxicação nos presos, e não apenas os que falavam e recebiam as mensagens nos vasos sanitários. Assim, também o telefone sem fio de vasos sanitários acabou por ser abandonado.

Como alternativa, Bezerra afirma que os presos tentaram domesticar camundongos e baratas, por falta do que fazer e por ainda ter o problema de comunicação entre os presos para resolver:

\footnotetext{
${ }^{35}$ BEZERRA, op. cit., p. 254.
} 
"Fizemos uma grande experiência. Pegamos uma grande barata, amarramos nela uma linha preta e exercitamo-la da seguinte forma: soltamo-la e deixamos que seguisse seu curso natural. Procurou esconderse. Puxamo-la a ré. Não gostando de ser arrastada, seguia para a frente e, depois, à esquerda. Fizemos isso várias vezes. E, cada vez que a soltávamos e a arrastávamos, ela ia mais longe e assim, aprendeu a virar para a esquerda e para a direita, conforme a nossa vontade. Podíamos fazêla entrar na porta vizinha à nossa cela. [...] Estava resolvido nosso problema de comunicação interna, com todos os companheiros da Cada de Detenção do Recife. Agora, cada célula confeccionava uma caixinha de papel na qual coubessem folgadamente cinco baratas das mais robustas. " 36

Se de fato o problema de comunicação entre os presos políticos foi resolvido com a domesticação de ratos e baratas, nós não temos como saber. Mas podemos compreender que o relato de Bezerra busca mostrar que, apesar do cárcere, parecia não haver obstáculos que os presos políticos não conseguissem ultrapassar. Sua fala traz um tom de heroísmo que tenta provar que os presos comunistas eram homens tão extraordinários que a prisão não os detém ou interrompe a sua militância em nada ou quase nada.

Há também na obra de Bezerra seu relato sobre uma greve que teria participado na Casa de Detenção. Ele conta que, por conta das péssimas condições em que eram mantidos na Casa de Detenção, os presos políticos teriam organizado o movimento em 1936. Dentre as reivindicações estavam a melhoria da higiene nas instalações, roupas limpas e sabão para higiene pessoal, mas também o direito a realizar banhos de sol regulares e receber visitas dos familiares. Segundo o autor, os presos políticos passaram a "não aceitar a boia e a gritar que estávamos morrendo de fome. Subimos às grades e gritávamos cada vez mais forte para as ruas. Juntava muita gente. " 3738

O tempo que Gregório Bezerra passou na Casa de Detenção de Recife foi o início dos dez anos que passaria privado de liberdade. Mais tarde, seria transferido para a colônia penal insular de Fernando de Noronha e para a Colônia Correcional de Dois Rios, em Ilha Grande, de onde seria libertado apenas em

\footnotetext{
${ }^{36}$ BEZERRA, op. cit., p. 259.

${ }^{37}$ Ibid., p. 260.

${ }^{38}$ Não encontramos menção sobre essa greve que menciona Bezerra, mas uma nota do Diário de Pernambuco afirma que o STM havia recebido um habeas corpus impetrado por 60 presos políticos que estavam na Casa de Detenção de Recife e se queixavam de maus tratos e má alimentação. Diário de Pernambuco, 4 de junho de 1937.
} 
1945. Entre o cárcere nas duas ilhas, ele ainda teria que enfrentar uma viagem de navio, assim como os outros autores que nelas também estiveram. É sobre essas viagens de navio a caminho das ilhas prisionais que tratamos a seguir.

\subsection{Nos navios: a prisão em deslocamento}

A passagem pela Casa de Detenção antecedia a ida para uma das ilhas prisionais, realizada sempre em navios. Heitor Ferreira Lima conta que, ao ser embarcado no navio que o levaria de Fortaleza para o Rio de Janeiro, foi encerrado em um cubículo estreito, "com rolos de toldos até a metade, de modo que só podia ficar sentado ou deitado incomodamente" onde "reinava escuridão completa; quando acendia a luz, era ela tão forte que me ofuscava a vista"; ali "havia uma faixa de metal amarelo de um palmo mais ou menos de largura, cheia de buracos redondos" que funcionava como única entrada de ar e que dava para o camarote dos foguistas do navio. ${ }^{39}$

Relata que, quando tinha necessidades fisiológicas, precisava comunicar a estes foguistas ${ }^{40}$, que em seguida avisavam ao cabo da guarda, este ao sargento do dia e em seguida ao oficial do dia - que concedia a autorização. Porém, às vezes a espera era prolongada: "Caso estivesse ele [o oficial do dia] jogando, minha espera era maior por não gostar de ser incomodado em tais ocasiões". Sobre a alimentação no navio, Lima conta que:

"De manhã cedo, sem lavar o rosto ou sequer passar água na boca, tomava um café horroroso, numa caneca enferrujada. As refeições eram trazidas em pratos de alguidar que mostravam pedaços enferrujados também, com gosto tão esquisito que não parecia comida."41

No caminho para o Rio de Janeiro, o navio atracou no porto de Natal, demorando-se um pouco ali. Heitor Ferreira Lima aproveitou a ocasião para enviar um bilhete à "cooperativa" dos sapateiros local, pedindo dinheiro e recebendo de volta vinte mil-réis. As aspas na palavra cooperativa são do próprio autor, o que é significativo pois denotam que o órgão não funcionaria apenas tal

\footnotetext{
${ }^{39}$ LIMA, op. cit., p. 160.

${ }^{40}$ Foguistas (ou fogueiros) são os profissionais que, em um navio a vapor, operam as caldeiras da embarcação.

${ }^{41}$ Ibid., p. 161.
} 
como o esperado ou que não era de fato uma cooperativa, mas provavelmente um aparato ligado ao partido. Conta também que um homem fardado, que não teria conseguido identificar, foi à porta de seu cubículo e lhe chamou, na tarde daquele mesmo dia. Falou-lhe que estava sendo preparada a sua fuga para a Bahia. O autor diz ter sabido depois, por meio de um "sargento do 'batalhão patriótico', gráfico de profissão, que conhecera de nome em Fortaleza e sabia ser simpatizante do Partido" que "em Natal haviam embarcado mais 'batalhões patrióticos' e haviam tentado [sua] fuga. $" 42$

No Rio, o autor passaria novamente pela experiência de deslocamento marítimo enquanto preso, porém agora por poucas horas, a caminho da Ilha Grande. Essa viagem teria sido feita no porão de um pequeno navio, em cujo centro havia um monte de pedras de carvão. Ali, os presos especulavam a respeito do provável destino: “Clevelândia, Fernando de Noronha, Dois Rios?” E, em tom de crítica, diz que atrás do monte de carvão "teve início a pederastia" entre os presos comuns - tema que tratamos melhor no próximo capítulo. Pela manhã, com o navio chegando à Dois Rios, os presos estariam com "roupas e rostos manchados de preto, como se estivéssemos mascarados" e que ao subir o convés para desembarcar, eles se depararam com uma "paisagem deslumbrante, lembrando uma aquarela". ${ }^{43}$

O desembarque na Ilha Grande se deu, como conta o autor, "em grupos de vinte, mais ou menos" colocados em uma "canoa grande, remada por correcionais, guiada por um guarda". Diz que ao alcançar a praia, os correcionais ofereciam-se para carregar os recém-chegados nos ombros, desde que lhes prometessem pagamento "pois, sem isso, fingiam tropeçar, caindo e molhando-nos inteiramente". Tal imagem pode nos parecer pouco provável, mas diz muito sobre a maneira como os presos políticos qualificavam os presos por crimes ditos comuns. Começava ali uma nova experiência na trajetória de encarceramento ou, nas palavras do próprio autor uma "nova história" se abria para aqueles homens.

Pouco antes de Heitor Ferreira Lima, Basbaum teria vivido a mesma viagem de navio. Sobre a ocasião, ele conta que os presos políticos foram

\footnotetext{
${ }^{42}$ LIMA, op. cit.,p. 161.

${ }^{43}$ Ibid, p. 164.
} 
despertados de madrugada com ordens de arrumar suas roupas e, ocupando vários tintureiros, foram levados para o cais do porto e embarcados "em um navio relativamente grande para tão curta viagem". O navio que os levaria, se o autor "não se engana”, era o "Anibal Benevolo, um velho cargueiro do Loide ${ }^{44}$, com o qual não nos atreveríamos, em condições normais, a ir a Niterói”.

O autor registra o espanto por não haver qualquer mobília dentro da embarcação: "Era apenas o navio, na sua estrutura de ferro, com meia dúzia de tripulantes para conseguir que o navio andasse sem rebentar as caldeiras, e uns cem soldados armados, espalhados pelo convés. ${ }^{, 45}$ Durante o dia de viagem, o autor afirma que os presos não tiveram nenhuma refeição, porém não lhes faltava água e que, ao anoitecer, foram todos dormir "arrumando, onde era possível, um lugar para se deitar, sempre com um olho vivo para os vagabundos". Ao acordar, no dia seguinte, Basbaum afirma que o navio já havia ancorado no litoral da Ilha Grande. ${ }^{46}$

Segundo Herondino Pereira Pinto, “o 'Iguaçú,, cargueiro do Lloyd Brasileiro $^{47}$, largara da praça Sérvulo Dourado, às 21 horas da noite de 22 de maio de 1936, justamente quando a Candelária encerrava uma novena em honra de Santa Maria." Ele e mais

"centenas de cidadãos, jurídica e socialmente qualificados, se comprimiam em cima da escotilha do imundo cargueiro, sob os maiores impropérios e ameaças violentas de dois sargentos da Polícia Militar, completamente embriagados, entre uma floresta de baionetas caladas."

O destino destes homens seria a Colônia Correcional de Dois Rios e a fala do autor tanto busca mostrar como a prisão daqueles homens era ilegítima afinal eram "cidadãos, jurídica e socialmente qualificados", quanto tenta deslegitimar a autoridade dos policiais por estarem embriagados e agindo com falta de respeito e truculência.

O navio teria seguido viagem lotado de presos políticos

\footnotetext{
${ }^{44} \mathrm{O}$ autor provavelmente se refere à Companhia de Navegação Lloyd Brasileiro.

${ }^{45}$ BASBAUM, op. cit., p. 131.

${ }^{46}$ Ibid., p. 132.

47 O cargueiro que Pereira Pinto se refere parece ter sido o navio Rio Iguaçu, da Companhia de Navegação Lloyd Brasileiro, empresa de navegação estatal brasileira criada em 1894 e privatizada em 1997, no âmbito do governo de Fernando Henrique Cardoso.
} 
"visivelmente cadavéricos, macilentos, barbados, de cabeleiras maltratadas, unhas sujas, epidermes feridas pela avalanche de parasitos, maltrapilhos, carregados de embrulhos de roupas velhas, bolorentas, com restos de pão nos bolsos negros e suados, sussurravam entre si, porque estavam proibidos de falar"

e estariam também "deitados, sentados uns por sobre os outros na escotilha da prôa engraxada pelos cabos das lingadas", demonstrando que o navio se constituía como uma extensão do cárcere ou como o cárcere em deslocamento. ${ }^{48}$

Pereira Pinto afirma que era madrugada quando o Rio Iguaçu ancorou na "Ilha dos Suplícios", forma como o autor se refere à Ilha Grande. E que os presos políticos foram recebidos por "algozes que se revesam [sic] em ordens violentas, lembrando os capitães do mato do tempo da escravidão"49, relacionando assim o tratamento violento dispensado pelos guardas da Colônia Correcional aos presos à violência perpetrada por capatazes aos escravos fugidos da época escravista.

Por sua vez, Gregório Bezerra afirma que os presos políticos, que como ele, encontravam-se na Casa de Detenção foram transferidos em abril de 1939 para Fernando de Noronha, onde já se encontravam os presos políticos enviados do Distrito Federal. Relata que a transferência se deu em meio a um aparato bélico que adjetiva como notável montado "desde a Casa de Detenção até o cais do porto, onde se achava à nossa espera o navio Rodrigues Alves. Saímos da Casa de Detenção do Recife em turmas de sessenta companheiros. "50

No navio, Bezerra conta que o oficial da polícia que os comandava havia dado ordem para que ficassem no porão até a saída da barra e só então poderiam subir ao convés, mas com a condição de que se comportassem bem. Uma vez que tiveram a permissão de subir ao convés, segundo Bezerra, "tudo correu muito bem até cerca das onze horas da noite, quando caiu uma chuvarada grossa" e os presos correram para se abrigar. Diante da correria dos presos políticos que fugiam da chuva,

"o capitão que comandava a escolta tomou o fato como uma desordem ou um princípio de revolta e ordenou à sua força que carregasse os fuzis e

\footnotetext{
48 PINTO, op. cit., p. 35.

${ }^{49}$ Ibid, p. 36.

${ }^{50}$ BEZERRA, op. cit., p. 274.
} 
colocasse as metralhadoras em posição de tiro contra nós: uma turma de soldados, de baioneta calada, fez-nos voltar ao porão do navio." 51

No porão do navio, Bezerra conta que muitos presos teriam começado a passar mal, pois "o calor era desesperador; a falta de ar, completa. Não havia a mínima ventilação." Ali, como nos navios que transportaram Leôncio Basbaum e Heitor Ferreira Lima para Ilha Grande, também não havia sanitários, o que transformava o ambiente claustrofóbico também em insalubre. Nesse contexto, os presos protestaram, pedindo ajuda ao médico de bordo e teriam recebido como resposta a ordem do capitão do navio de manter o porão aberto mas com soldados apontando fuzis para intimidar os presos. No meio dessa tensão, Bezerra afirma que os presos ofereceram os seus peitos aos fuzis e conseguiram, aos poucos, retornarem ao convés. A viagem teria prosseguido assim, com presos e soldados alertas uns com os outros e, a primeira coisa que teriam feito os presos políticos ao desembarcar na praia de Santo Antônio, em Fernando de Noronha, foi receber as boas-vindas de companheiros de militância enviados do Rio de Janeiro e tomar um banho de mar enquanto o comandante do navio conversava com o coronel Veríssimo, provavelmente colocando o diretor do presídio a par da confusão que havia ocorrido a bordo. Chegava ao fim a tensão instalada no navio mas começava o cotidiano prisional insular.

\section{4. $O$ cárcere final: ilhas prisionais}

Após passagem pelas Casas de Detenção e do deslocamento marítimo em navios em condições apontadas por todos os autores como precárias, os presos políticos chegavam às ilhas prisionais, cárceres onde passariam o tempo final de suas penas. Há indícios de que, desde o século XVII, degredados eram transportados à Fernando de Noronha, porém o início da longa história da ocupação penal do arquipélago se dá em 1737 quando os primeiros sentenciados militares, desterrados e condenados a penas de galés foram enviados como mãode-obra para construção de fortalezas - uma reação à ocupação daquela região por holandeses e franceses. ${ }^{52} 53$ Já o regime civil do presídio começa oficialmente

\footnotetext{
51 Ibid., p. 274, 275.

$52 \mathrm{O}$ arquipélago de Fernando de Noronha, no litoral de Pernambuco, é formado por 21 ilhas e ilhotas, das quais a ilha homônima tem $8 \mathrm{~km}^{2}$ de extensão territorial.
} 
apenas em 1833, com um decreto imperial que definia que o cumprimento de penas de galés perpétuas ou temporárias impostas aos condenados por fabricação de moeda falsa deveria se dar na ilha-prisão. ${ }^{54}$ Assim, tem início o processo que torna a ilha uma prisão central para o Brasil Imperial; na prática, acaba passando a funcionar como um depósito de condenados de todos os tipos, recebendo também militares e escravos condenados. ${ }^{55}$

O envio de novos sentenciados para Noronha foi proibido em 1894, por conta do esvaziamento da população de presos devido a Guerra do Paraguai (1864-1870). A prisão foi perdendo importância e em 1897 foi fechada, sendo seu território integrado ao estado de Pernambuco, que a utilizou como prisão ao longo da Primeira República. Na década de 1930, com o envio de alguns dos presos políticos que lotavam os cárceres continentais, Vargas sancionou um decreto-lei que transformou a ilha-prisão em Colônia Agrícola de Fernando de Noronha e devolveu a jurisdição ao Governo Federal. Segundo a letra da lei, a ilha passou a ser destinada "à concentração e trabalho de indivíduos reputados perigosos à ordem pública, ou suspeitos de atividades extremistas". ${ }^{56}$

Agildo Barata e Gregório Bezerra, por terem tido papéis de liderança nos acontecimentos que os levaram à prisão encaixavam-se na categoria de “indivíduos reputados perigosos à ordem pública" e foram enviados ao arquipélago. Bezerra afirma que, após o banho de mar do momento de desembarque em Noronha, "nós, com os demais companheiros, fomos para o alojamento central dos presos políticos aliancistas. "E explica que havia um "alojamento central dos aliancistas porque havia também um alojamento central para os presos integralistas que também estavam na ilha", demonstrando que além

${ }^{53} \mathrm{O}$ missionário capuchinho Claude d'Abbeville narra o encontro com alguns desterrados - um português e dezoito índios que viviam na ilha por volta de 1612 no livro "História da missão dos padres capuchinhos na ilha do Maranhão e suas circunvizinhanças", publicado em 1614.

${ }^{54}$ Lei no 52 de 3 de outubro de 1833, definiu Fernando de Noronha como local para o cumprimento das sentenças dos condenados por fabricação, introdução e falsificação de notas, cautelas, cédulas e papéis fiduciários, determinando a aplicação da pena de galés, isto é, trabalhos públicos forçados.

${ }^{55}$ COSTA, Marcos Paulo Pedrosa. Fernando e o mundo - o Presídio de Fernando de Noronha no século XIX. Em: BRETAS, Marcos, COSTA, Marcos, MAIA, Clarissa, NETO, Flávio de Sá. História das prisões no Brasil. Rio de Janeiro: Rocco, 2009. p. 135 - 167.

${ }^{56} \mathrm{O}$ texto do Decreto-Lei $\mathrm{n}^{\circ} 640$ de 22 de agosto de 1938 está disponível em: http://www2.camara.leg.br/legin/fed/declei/1930-1939/decreto-lei-640-22-agosto-1938-350872publicacaooriginal-1-pe.html. Acessado pela última vez em 23 de março de 2018. 
de haver uma separação entre os presos políticos que para lá eram enviados, esta era baseada na polarização política e ideológica entre eles. ${ }^{57}$ Essa polarização definiu a organização das atividades e tarefas do cotidiano prisional. Segundo, Mário Magalhães, autor da biografia de Carlos Marighella, preso político que também afirma que:

"Sem considerar os minoritários presos comuns mantidos para prestar serviços à administração, os condenados se apartavam em dois grupos: por volta de noventa integralistas e 180 militantes de esquerda, quase todos da extinta ANL, com hegemonia comunista. Não se misturavam: camisasverdes se acomodavam num prédio, aliancistas em outros - no alojamento maior, em duas edificações médias também de alvenaria e em casas nas quais cabia meia dúzia de pessoas. As casinhas se erguiam com pedras, cobriam-se de palha de coco e tinham o chão de terra. "58

Os referidos alojamentos provavelmente eram construções erigidas pelos próprios sentenciados, pois em quase seus duzentos anos de existência, a colônia penal sempre teve "por paredes o mar, e a própria ilha era a prisão. Não existia um presídio enquanto edifício, com celas, grades e muros", como afirma Marcos Costa, e desde as primeiras construções, estas foram feitas através de mão-de-obra penal. No século XIX, as construções do presídio eram reunidas na vila dos Remédios: em volta de duas praças concentravam-se as casas de funcionários e presos e edificações públicas como o armazém, a enfermaria, hospital, escola e a Igreja de Nossa Senhora dos Remédios, além do prédio chamado Aldeia, com espaço para poucos presos. ${ }^{59}$

Por ser uma colônia penal, os presos historicamente tinham como obrigação a realização de trabalhos braçais, porém sobre essa questão Bezerra diz que:

"Tínhamos, através do coletivo, uma política de colaboração com a diretoria do presídio: fazíamos o descarregamento e o carregamento dos navios, quando chegavam e saíam, e armazenávamos as mercadorias. Fornecíamos verduras a todas as famílias da ilha, ao hospital, ao destacamento policial e a todos os que estavam doentes, inclusive aos

\footnotetext{
${ }^{57}$ BEZERRAa, op. cit., p. 275, 276.

${ }^{58}$ MAGALHÃES, Mário. Marighella, o guerrilheiro que incendiou o mundo. São Paulo: Cia das Letras, 2012. p. 32.

${ }^{59}$ COSTA, op. cit., p. 138, 139.
} 
integralistas. Em troca, a diretoria nos fornecia os instrumentos de trabalho necessários. ${ }^{" 60}$

Gregório Bezerra se refere às atividades laborais realizadas pelos presos políticos como fruto de uma "política de colaboração com a diretoria", contudo o regime de trabalho sempre foi uma característica daquela colônia penal, o que tornava difícil haver alguma margem de negociação sobre sua realização. Ele diz, mais adiante, que tinham também permissão para realizar pesca, cultivar vegetais e frutas e ainda tinham um aviário, mas é possível que essas atividades fossem parte do trabalho que os presos em geral deveriam realizar e não uma permissão dada apenas ao grupo do qual fazia parte. Apesar disso, o autor afirma que "o fato é que fome mesmo nunca passamos. "61

Por não haver presídio celular, os presos políticos de esquerda tinham como responsabilidade o preparo de sua própria "boia"; provavelmente os presos por crimes ditos comuns e integralistas também cozinhavam suas próprias refeições, mas sobre as atividades realizadas por estes outros o autor não menciona. Ao falar sobre alimentação, Bezerra afirma, por exemplo, muitas vezes faltava sal, mas "sempre tínhamos sal, porque íamos à praia do Cachorro munidos de latas de querosene, que enchíamos de água do mar e colocávamos ao fogo até evaporar a água e ficar só o sal", o que é factível, mas na narrativa do autor, os presos políticos sempre aparecem como os grandes responsáveis por realizações que nenhuma outra categoria de pessoa seria capaz. Junto com um companheiro a quem chama de Aço, Bezerra diz ter planejado sua fuga do arquipélago, visando alcançar as praias do litoral do Rio Grande do Norte ou do Ceará, baseado nas histórias de um velho preso por crimes ditos comuns ao qual se refere como Laranjeira. $\mathrm{O}$ autor afirma que Laranjeira, condenado a trinta anos de prisão,

"conhecia a ilha e sabia de todas as fugas e tentativas de fugas em Fernando de Noronha desde vinte anos antes, as que tiveram êxito e as que fracassaram por delação, naufrágio ou por terem os fugitivos sido presos nas costas do Rio Grande do Norte ou do Ceará. "62

Munido das informações coletadas com Laranjeira, Bezerra e Aço teriam construído uma jangada de mulungu em um lugar da ilha onde não seriam vistos e

\footnotetext{
${ }^{60}$ BEZERRA, op. cit., p. 276.

${ }^{61}$ Ibid, p. 277.

${ }^{62}$ Ibid, p. 286.
} 
de onde partiriam para o mar. Eles teriam tido ajuda de outros dois presos políticos, o ex-cabo Ananias e Piauí, que teceram e costuraram a vela para a jangada. Entre o planejamento e a construção da jangada para a fuga, teriam se passado seis meses e o dia da partida, em fins de maio de 1941, quando deixaram uma comunicação ao coletivo e um bilhete à direção partidária pois "tínhamos consciência do ato de indisciplina que íamos cometer perante o partido e o coletivo, mas estávamos dispostos a arcar com toda a responsabilidade. "

Porém, mal haviam posto a jangada no mar, ondas fortes a emborcaram: "Ficamos de cabeça para baixo", diz Gregório. Eles tentaram desvirar a jangada, mas não havia mais jeito a não ser voltar à terra firme, onde enterraram a embarcação e as latas que levavam mantimentos e água doce, de forma que não sobrasse nenhum vestígio da empreitada. Quando retornaram ao alojamento, a direção dos presos políticos de esquerda já teria tomado conhecimento de tudo:
"fomos prestar contas à direção do coletivo [...] A discussão não foi produtiva. [...] Tive pela primeira vez um sério atrito com o camarada Agildo Barata, a quem admirava e estimava muito como um excelente companheiro de luta. Mas não podia aceitar os termos de sua crítica. O camarada Ghioldi, o mais experimentado e o mais capaz politicamente, contornou a situação: propôs que tivéssemos uma discussão política com os camaradas Agliberto Azevedo e José Francisco de Oliveira e que o resultado dessa discussão fosse levado à direção do coletivo. Foi uma discussão serena, fraternal. Achamos justa a crítica e levamos nossa autocrítica à prática, não repetindo o erro de uma nova fuga, que era nosso objetivo." 63

Assim, a tentativa de fuga de Bezerra teria fracassado e criado uma questão tensa entre aqueles presos. Mas, logo Bezerra se veria longe de Noronha pois "do fim de 1941 para o início de 1942, [...] começaram a surgir boatos de que o arquipélago de Fernando de Noronha seria transformado em base militar", o que de fato ocorreu. E conta que:

"No início de 1942, o general Mascarenhas de Morais veio verificar a situação estratégica da ilha e, poucos meses depois, nós fomos transferidos para a Ilha Grande, no Estado do Rio de Janeiro, ficando alojados no presídio político da colônia de Dois Rios. "64

\footnotetext{
63 BEZERRA, op. cit., p. 285-288.

${ }^{64}$ Ibid., p. 289.
} 
Bezerra registra, então, suas impressões sobre Ilha Grande, ao compará-la com a ilha-prisão que estivera antes:

"Quanto às vantagens da Ilha Grande sobre Fernando de Noronha, foram enormes", diz Bezerra, comparando as duas prisões insulares. Fernando de Noronha, apesar dos "excelentes cajus, mamãos deliciosos, pinhas [...], bananas e muito peixe", teria uma água "além de ruim e poluída, provocava-nos uma disenteria constante" e uma "nuvem de mosquitos, que não deixava ninguém dormir sossegado, além de outros animais. Reclama também que a correspondência "além de demorada, era severamente censurada" e os presos não teriam como receber visitas. Na Ilha Grande, a água que os presos teriam acesso seria excelente, segundo o autor, e eles podiam receber visitas, afinal a ilha tinha acesso mais fácil ao continente do que a anterior. E relaciona o fim da Segunda Guerra Mundial com o afrouxamento da vigilância: "à medida que os fascistas iam sendo esmagados nos campos de batalha, íamos tomando conta da praia, sem o acompanhamento dos guardas". 65

Diferente de Fernando de Noronha, que tinha já um longo passado penal quando os presos políticos do regime Vargas lá desembarcaram, a Ilha Grande só começou a funcionar como um presídio militar a partir de 1894, quando foi transformado o Lazareto que lá existia desde 1884. A construção era fruto de um conjunto de iniciativas que, desde meados do século XIX, buscavam expandir o controle preciso sob os indivíduos e seus movimentos. No fim de 1894, a Colônia Correcional de Dois Rios foi criada, a partir da fazenda de mesmo nome, que antes servia de apoio ao Lazareto. Nas primeiras décadas do século XX, a Colônia passa a receber cada vez mais presos acusados de contravenções, enquanto que o Lazareto passa a ser utilizado como prisão militar para os presos provenientes da repressão dos movimentos tenentistas em 1922 e 1924 e, mais tarde ambas as construções recebem os presos da Revolução Constitucionalista de 1932 e dos levantes comunistas de $1935 .^{66}$

Preso sem acusação ou processo no momento em que estourava a revolta paulista, Heitor Ferreira Lima afirma que estaria há menos de uma semana nas dependências da Casa de Detenção da Capital Federal quando surgiram murmúrios de que uma leva de presos seguiria para a Colônia Correcional Dois Rios. Conta que a notícia entreouvida "parecia verdadeira, transformando o

\footnotetext{
${ }^{65}$ BEZERRA, op. cit., p. 290.

${ }^{66}$ SEPÚLVEDA, Myrian. Os porões da República: a barbárie nas prisões da Ilha Grande:
}

1894-1945. Rio de Janeiro: Garamond, 2009. p. 72-91, 156, 182. 
ambiente e as fisionomias. A tranquilidade e quase alegria antes reinante transformava-se em preocupação, com as fisionomias carregadas. ${ }^{967}$ Explica que a preocupação que se instalou entre os presos políticos tinha a ver com dois motivos. O primeiro se refere ao fato de que estavam todos " detidos às ordens do chefe de polícia', sem culpa formada nem processo instaurado", podendo serem postos em liberdade a qualquer momento. Porém, sendo enviados ao presídio da Ilha Grande, esse panorama mudaria, com a esperança de libertação cada vez mais distante, aumentando a perspectiva de que a prisão seria prolongada.

Preocupação parecida demonstra Basbaum que afirma que ele e seus companheiros não sabiam quanto tempo iriam passar em Ilha Grande pois não eram condenados, não tinham processo e não estavam sob os cuidados da justiça. "Isolados do mundo, poderíamos ficar ali anos e anos, ou, quem sabe, até ao fim da vida. "Reflete o autor, que afirma que na Casa de Detenção pelo menos o Socorro Vermelho teria alguma possibilidade de encontrar-lhes um advogado, mas o isolamento da prisão insular tornaria isso muito difícil, além do fato de que naquele momento Getúlio Vargas teria decretado estado de sítio, por conta da Revolução Constitucionalista em São Paulo, o que suspendia os direitos. Apesar disso, Basbaum afirma que eles tinham esperanças de que fossem libertados assim que o movimento paulista chegasse ao fim. ${ }^{68}$

O segundo motivo para Ferreira Lima e seus companheiros mostrarem-se preocupados tinha a ver com o imaginário acerca da ilha prisional. Nas palavras do autor:

"A Colônia Correcional era o presídio mais abjeto que havia, para onde mandavam a escória da malandragem, $[. .$.$] gente sem o menor sentimento$ humano nem escrúpulo ou qualquer consideração pelos outros e ainda com trabalhos forçados e sujeitos a constantes surras com vara de marmelo." 69

É nesse clima de apreensão por esperar o pior, que os presos foram transferidos para a Ilha Grande - ou para a "Ilha dos Suplícios", como chama Herondino Pereira Pinto. Ferreira Lima narra que ao anoitecer, apareceram nas celas guardas com listas constando os nomes de quase todos os presos políticos e

\footnotetext{
${ }^{67}$ LIMA, op. cit., p. 163.

${ }^{68}$ BASBAUM, op. cit., p. 133, 134.

${ }^{69}$ LIMA, op. cit., p. 163, 164.
} 
alguns presos comuns, que foram encaminhados para um tintureiro, "onde o calor era sufocante, aumentando à medida que subiam os demais. [...] O carro já estava lotado, porém continuavam empurrando mais pessoas, provocando protestos, que os guardas respondiam com palavrões. " O tintureiro lotado levou-os da rua Frei Caneca para o arsenal da Marinha, onde foram conduzidos ao porão do pequeno navio que havia ali atracado e que os transportou até a Ilha Grande, onde teriam chegado ao nascer do dia. ${ }^{70}$

Segundo o autor, "os recém-chegados são os primeiros a saírem em fila, escoltados, para o almoço". Apesar disso, reclama que a refeição servida era precária: "feijão e arroz duros e sem gosto, acompanhados de pedaço de carneseca, com manchas arroxeadas pela podridão e pequeno pão, também duro, servido em pratos de folhas de Flandres e colher meio enferrujada. "Após o almoço, esses novos presos teriam um momento para ficar no pátio do presídio, que se constituía, segundo o autor, como a ocasião em que "os presos comuns compram, a dinheiro ou em troca de cigarros, esteiras, cobertores e outros objetos de uso [pessoal]", enquanto que os presos políticos acabavam por receber essas coisas "gratuitamente" dos presos políticos que lá já se encontravam, por camaradagem. Se de fato isso ocorria, não nos importa muito, mas é necessário notar que os presos políticos sempre aparecem agindo de forma solidária entre si, enquanto os presos qualificados como comuns sempre agem de forma mesquinha ou mesmo criminosa. ${ }^{71}$

Ferreira Lima conta também que esse primeiro dia na prisão em Ilha Grande teria sido marcado pelo que ele ouviu um preso chamar de "escrache", termo que denota que já se sabe do que é referido. Acontece que os presos novatos eram chamados para formarem filas em frente à Diretoria, onde passavam por um processo de "identificação e rapidíssimo exame médico, consistente em simples olhar da cabeça aos pés", depois recebiam um papel com um número escrito, pelo qual deveriam responder dali em diante, e roupas novas - "calça e blusa de gola em pé, com listras azuis horizontais: era a zebra". Puderam também tomar um

\footnotetext{
70 Ibid., p. 164, 165.

${ }^{71}$ LIMA, op. cit., p. 165.
} 
banho frio, de onde "saindo tiritantes, por falta de toalha para nos enxugarmos e enfiamos a zebra no corpo molhado". ${ }^{72}$

Por sua vez, Basbaum conta que, ao chegar na Ilha Grande, o seu grupo de presos foi recolhido ao presídio, que "se constituía de uma série de galpões de alvenaria e telha, emendados uns aos outros, formando um quadrado, sem janelas por fora e dando saída para um pátio interno que teria o tamanho de metade de um campo de futebol”. O galpão que Basbaum e seus companheiros teriam ocupado "era rodeado internamente por um estrado de madeira", no qual eles dormiriam em colchões infestados de percevejos e onde já haviam alguns presos comuns.

Logo no dia seguinte de sua chegada, os presos políticos novatos ali teriam sido divididos para as turmas de trabalho da lenha e da viga. Conta que:

"O trabalho da turma da lenha era mais suave: tinha de subir o morro e apanhar a lenha cortada no dia anterior por alguns presos e trazê-la para baixo, para a cozinha. A lenha era carregada nos ombros, em feixes, e havia um número mínimo de achas que cada um devia carregar, pudesse ou não. "73

Basbaum, contudo, teria sido incorporado à turma da viga, na qual os presos tinham como tarefa "subir o morro e 'encaminhar' a viga para baixo. Essa viga era um tronco de árvore derrubada na véspera, por um grupo de presos comuns. "O trabalho se constituiria como "extremamente perigoso" pois, diz o autor, "já havia vários casos de morte entre presidiários que se encontravam no caminho da viga em sua corrida vertiginosa para baixo, dentro de uma trilha que as próprias vigas haviam cavado. "Sua função nessa turma era portar um machado, com o qual deviera aparar as pontas de galhos que impediam a descida das vigas - o que provocava brincadeira por parte dos presos políticos que conheciam Basbaum pelo seu nome de guerra, que era justamente Machado.

Um tempo depois, Basbaum foi enviado para conversar com o médico do presídio, o doutor Hermínio Ouropretano Sardinha que, segundo o autor, era "um homenzinho magro, que gostava de bancar o homem mau, mas se percebia que

\footnotetext{
${ }^{72}$ Ibid, p. 166.

${ }^{73}$ BASBAUM, op. cit., p. 132 - 135.
} 
apenas se vingava da humanidade que o havia empurrado para ser médico [...] de um bando de vagabundos". Para provar ser médico formado, o dr. Sardinha exigiu que Basbaum lhe desse alguns nomes de professores de medicina. Assim, Leôncio Basbaum foi transferido da turma de vigas para tomar conta do hospital que ficava perto da praia, distante uns 200 metros do presídio e se constituía de uma casa com poucos cômodos, alguns leitos, um escritório consultório, mas onde "nele o médico nunca aparecia". "Na ocasião [da transferência de Basbaum] havia apenas um doente: um homem tuberculoso que estava apenas esperando a hora de morrer pois não havia tratamento para ele. "Enquanto trabalhou no hospital, Basbaum atendeu presos com perturbações intestinais e doenças venéreas, sendo estas "tratadas como sífilis (não havia ainda antibióticos nem sulfas) com injeções de 914, o grande remédio da moda" e muitos casos de avitaminose, "para os quais não tínhamos tratamento, a não ser pomadas inócuas, quando se revelavam por úlceras nas pernas. $" 74$

Neste capítulo, buscamos compreender os indícios que os presos políticos nos dão sobre a experiência que tiveram ao serem encarcerados nas ilhas de Fernando de Noronha e Ilha Grande, nas Casas de Detenção do Rio, de Fortaleza e de Recife e de terem vivido o deslocamento marítimo enquanto presos. Estes indícios ao contrário de nos mostrar uma vida carcerária monótona, em que os presos passam anos numa cela quase sem contato, nos mostram que os autores ao serem presos, construíram uma vida social rica, cheia de tensões, trocas, negociações e atividades. Assim, não há uma interrupção da maneira como os autores já viviam a militância quando em liberdade, mas há transformação e adaptação às possibilidades dentro da prisão.

A despeito das intenções biográficas e escolhas narrativas feitas por cada autor, suas memórias da trajetória de prisão descortinam um cotidiano prisional em que os presos políticos vivem a sua militância intramuros de forma intensa, onde em diversos momentos se tocam com autoridades estatais e nos mostram que nem sempre essa relação se dá da mesma forma. Por vezes, esse contato é tenso, como no episódio do embate entre presos e soldados dentro do navio que levava Bezerra para Fernando de Noronha ou mesmo pode vir a se tornar amigável, como

\footnotetext{
${ }^{74}$ BASBAUM, op. cit., p. 135, 136.
} 
quando o próprio autor afirma ter desenvolvido amizade com o guarda-cárcere que antes o vigiava com tanto afinco.

Isso mostra que as diferentes instâncias de autoridades estatais se tocavam com os presos de formas diferentes. A maneira como um guarda-cárcere ou um foguista do navio lida com o preso político envolve tensões e negociações diferentes da relação estabelecida com o diretor da prisão. Dificilmente Bezerra conseguiria engajar um dos diretores das prisões em que esteve, por exemplo. O que nos faz questionar se os presos tinham noção das tensões envolvidas nas relações entre os sujeitos que detinham diferentes níveis de autoridade estatal. No entanto, sem ter essa resposta, passamos ao próximo capítulo, onde buscamos entender a relação travada entre os próprios presos políticos e os presos por crimes ditos comuns. 


\section{Os presos comuns nas narrativas de presos políticos}

$\mathrm{Na}$ análise das trajetórias de encarceramento dos autores das obras que compõem nosso corpus documental, buscamos até aqui compreender como eles narraram suas experiências de prisão política nas Casas de Detenção, nas ilhas prisionais de Fernando de Noronha e a experiência de deslocamento em navios entre esses cárceres durante as décadas de 1930 e 1940. O presente capítulo intenta lidar com outra questão que se apresenta no nosso recorte analítico: a construção de subjetividade na narrativa do cotidiano prisional. Como os autores, ao narrar as experiências de prisão política que tiveram, acabaram por construir uma identidade para a categoria de preso político? Ao fazê-lo, como acabaram por construir uma imagem do outro, de forma dialética, oposta a imagem que construíram para si?

Para tanto, este capítulo se divide em duas partes. A primeira dedica-se à análise da noção de "coletivo" e como esse termo é articulado na narrativa da experiência prisional e na maneira como os autores descreveram a si mesmos. A segunda parte busca compreender a imagem do outro visto como contrário de si, que por vezes é projetada nos guardas e nos presos políticos integralistas, mas principalmente nos presos por crimes ditos comuns. Para entender essa dialética da construção de si prisional, levamos em conta os relatos acerca da relação que os autores travavam entre os indivíduos que enxergavam como semelhantes e também o que diz respeito às relações que estabeleceram com os outros indivíduos que não se encaixavam na categoria de preso político, mas com os quais conviveram na prisão.

\subsection{O Coletivo}

Segundo Agildo Barata, "um dos aspectos mais característicos da vida presidiária dos presos políticos de esquerda é a existência do 'coletivo'. Tão depressa são encarcerados, os esquerdistas passam a organizar o Coletivo. "1 Já vimos anteriormente que Barata definia a si mesmo como um revolucionário,

\footnotetext{
${ }^{1}$ BARATA, Agildo. Vida de um revolucionário (memórias). São Paulo: Alfa-Ômega, 1978, p. 310.
} 
demonstrando assim o quanto a militância e a política tinham papel central na sua vida. Tanto o autor quanto os outros nomes que assinam os livros que compõem nosso corpus documental encaravam a militância de forma orgânica, ao ponto do encarceramento interferir pouquíssimo na sua dinâmica e pouco alterar seu comportamento enquanto militante, pois a política deveria permear toda a sua vida, em qualquer espaço, em qualquer momento.

Em todas as obras autobiográficas analisadas neste trabalho, o coletivo aparece como uma questão importante apontada pelos autores pois o militante de esquerda não poderia deixar de sê-lo mesmo quando estivesse encarcerado. A prisão deveria se transmutar para ele em mais um espaço de socialização da militância e o coletivo era o meio em que isso deveria se realizar, onde a sua militância intramuros deveria se tornar viável. A construção da identidade do preso político de esquerda, nos autores que trabalhamos, passa necessariamente pela forma como eles articularam essa ideia à experiência cotidiana de organização na prisão - por conta disso, faz-se necessário analisar essa noção, desessencializando-a.

\begin{abstract}
Ainda segundo Barata, o coletivo funcionava como
"um organismo democrático: os cinco membros de sua diretoria eram mensalmente eleitos. E podemos afirmar: de 1935 a 1945 o único lugar onde havia democracia, no Brasil, e onde se realizavam eleições era nos presídios políticos onde a ditadura confinava os presos políticos da esquerda."
\end{abstract}

Também Gregório Bezerra se refere ao coletivo como um organismo democrático e nos dá uma explicação sobre a forma como essa democracia se realizava dentro da prisão:

"Nossa eleição bimensal do coletivo para a direção era democrática. A direção que saía apresentava a chapa oficial, mas a massa tinha o direito de propor emendas ou mesmo modificar toda a chapa oficial. Cada direção que saía promovia a reunião de todos para a votação. Depois da votação e da apuração, servia-se uma boa ceia. Era uma pequena festa, em que não faltavam piadas e humor, o que muito alegrava o pessoal. Todas as eleições eram acompanhadas de uma prestação de contas correspondente aos dois meses em atividades. "3

\footnotetext{
${ }^{2}$ BARATA, op. cit., p. 311.

${ }^{3}$ BEZERRA, Gregório. Memórias. São Paulo: Boitempo editorial, 2011, p. 279.
} 
Como podemos notar, a qualidade democrata atribuída ao coletivo tinha a ver com uma crítica ao regime ditatorial de Getúlio Vargas, que se manteve durante 15 anos no poder e promoveu uma repressão que, dentre inúmeras consequências, lotou os presídios do país de presos políticos. A democracia do coletivo também era notada pelos autores na realização de eleições para a sua direção, isto é, significava a possibilidade de votar para escolher quem os representaria na direção. Dentro dessa noção de democracia como possibilidade de escolha dos representantes, havia também a oportunidade de discordância com os antigos líderes, podendo a discordância vir a se tornar uma mudança concreta inclusive tornando viável "modificar toda a chapa oficial".

Significa dizer que os presos comunistas encontravam dentro da prisão um espaço para o dissenso político que não existia fora dali. Podemos também notar que o momento democrático dentro do coletivo era uma oportunidade de exercício da militância política, não só por conta da votação para a nova direção, mas também pela "prestação de contas" dos dirigentes que deixavam o cargo. Além disso, era uma ocasião para uma socialização mais descontraída pois, como relata Bezerra, a eleição era acompanhada de uma "pequena festa", momento que "muito alegrava o pessoal".

Ao se referir ao tempo que esteve na Casa de Detenção, Gregório Bezerra afirma que o coletivo dos presos de esquerda ali tinha duas organizações: uma de massa, a Comissão Central dos Coletivos (CCC), e outra partidária, que orientava a primeira e cuidava das questões políticas. $O$ autor relata que atuou como presidente da primeira organização e foi membro do secretariado da direção política. Com outros termos, mas mostrando que os presos comunistas sempre buscavam se organizar inspirando-se nas estruturas hierárquicas que haviam conhecido quando em liberdade que aparece na narrativa de Bezerra, Heitor Ferreira Lima diz que o coletivo e a célula do PCB não se confundiam, pois "a célula do Partido reunia-se separadamente, composta só por comunistas, abordando temas políticos e dirigindo o coletivo" e que este era composto "de [um] ajuntamento de comunistas e simpatizantes, vivendo e atuando separadamente dos presos comuns, malandros da pior espécie”. 
A fala de Ferreira Lima denota também que havia uma separação no cotidiano prisional entre os presos políticos e os presos comuns que ia além da diferença de categorias de crimes nas quais foram condenados e encarcerados exploraremos isso melhor mais adiante, na segunda parte deste capítulo. Mas o que podemos perceber até aqui é que os presos políticos de esquerda tentavam reproduzir na prisão as estruturas hierárquicas partidárias e a experiência de militância que vivenciavam antes em liberdade. O coletivo operava como o PCB, mas não era um partido, era parte dele e da sua rede de sociabilidade. Para esses autores, então, a noção de democracia não era necessariamente contraditória à hierarquia partidária até certo ponto rígida se lembrarmos que o Partido Comunista do Brasil de então era diretamente influenciada pela União Soviética stalinista.

Os autores apontam, quando falam sobre o coletivo, que a organização tinha como objetivo a realização de algumas funções e atividades. Barata, após definir o que era o coletivo, afirma que, logo ao ser formado o "organismo passa[va], então, a coordenar as atividades dos presos políticos de esquerda e a representá-los nas inevitáveis relações com as administrações dos presídios. "4 Mostrando, então, que o coletivo tinha origem na necessidade dos presos políticos serem vistos enquanto um conjunto coeso diante das autoridades prisionais. Por sua vez, Leôncio Basbaum demonstra que havia uma grande importância atribuída à função de manter os presos políticos como militantes ativos quando narra que, ao chegar na Casa de Detenção do Rio de Janeiro após transferência, os presos trataram logo de organizar o coletivo, "composto de cinco pessoas, e a distribuir o tempo, marcando horas de discussão e estudos teóricos para os que quisessem: marxismo, situação brasileira, União Soviética, socialismo etc." ${ }^{5}$

Como para estes homens as ideias deveriam orientar e dar forma à prática política, podemos compreender o quanto o coletivo deveria exercer a função de organizar o cotidiano prisional de forma que o tempo encarcerado não fosse em vão, não fosse tempo perdido em que eles não mantiveram atividades políticas. Do contrário, deveria valer de aprendizado político para aqueles indivíduos que

\footnotetext{
${ }^{4}$ BARATA, op. cit., p. 310.

${ }^{5}$ BASBAUM, Leôncio. Uma vida em seis tempos (memórias). São Paulo: Alfa-Ômega, 1978, p. 127.
} 
tinham consciência de viver sempre sob a possibilidade de repressão política e de uma nova prisão. Barata menciona as funções de "coordenar as atividades" e representar os presos políticos "nas inevitáveis relações com a administração dos presídios", dando a ver que havia uma dinâmica de atividades cotidianas realizadas pelos presos e que as relações que travavam com os outros na prisão dependia de uma mediação que se tornava possivelmente menos desequilibrada quando feita de forma coletiva.

As atividades realizadas pelo coletivo que os presos mencionam tinham natureza pedagógica, social, política, econômica e de recreação. Acima, Basbaum fala sobre as "horas de discussão e estudos teóricos", que se encaixariam na categoria de atividades que tinham cunho pedagógico, mas também político. Barata nos relata sobre a existência do que chama de "Universidade do Coletivo" na qual "o Coletivo organizava cursos de humanidades, começando por liquidar o analfabetismo. [...] Havia cursos de Filosofia, de Economia Política e cursos de História Universal e do Brasil”. O autor também afirma que ocorriam conferências "de nível bastante elevado e realizadas por conferencistas de notável saber" e cita nomes como Maurício Medeiros, Hermes Lima, Castro Rabelo, Leônidas Rezende, Rodolfo Ghioldi e Frederico Carpenter. ${ }^{6}$ Podemos entender que a necessidade de estudos teóricos e discussões sobre diversos temas era fruto tanto uma necessidade de manter a militância ativa quanto da existência de presos políticos que antes atuavam como intelectuais, professores universitários, teóricos do Partido, etc quando em liberdade.

Por sua vez, Bezerra demonstra que para além das atividades com horários fixos estabelecidos pelo coletivo, havia também espaço para atividades extraordinárias, que surgiam da necessidade do momento. Assim, o autor nos conta que, ao acompanhar "com atenção e entusiasmo" as notícias da Segunda Guerra Mundial no rádio clandestino que os presos políticos em Fernando de Noronha tinham, "o pacto de não agressão entre a URSS e a Alemanha nazista deu motivos a muitas conferências políticas de nosso querido camarada Rodolfo Ghioldi e de outros camaradas de nosso coletivo", mostrando que a vida política e

\footnotetext{
${ }^{6}$ BARATA, op. cit., p. 311-312.
} 
social dentro da prisão insular não se mostrava tão diferente do que seria fora, mas continuava ativa e adaptada às possibilidades disponíveis ali. ${ }^{7}$

Já as atividades com funções recreativas são onde se encaixam as ocasiões em que os presos produziam algum entretenimento para seu próprio grupo, mas mesmo estas não eram alienadas do caráter político e militante. Bezerra conta que os presos políticos em Fernando de Noronha organizaram festejos natalinos e juninos enquanto estiveram naquela ilha e que estas visavam "três objetivos: o econômico, o político e o recreativo". Entendiam dessa forma provavelmente porque as festas se mostravam momentos em que os presos políticos podiam, além de se divertir, comercializar o que produziam, acumulando algum dinheiro, e também exercitar sua militância política, através da socialização com outros presos, funcionários e moradores da ilha.

O autor também relata a criação de um time de futebol dos presos políticos chamado "Os Diabos de Fernando" e Barata enfatiza o quanto o teatro e a música eram importantes formas de entretenimento para fazer o tempo passar, ao contar sobre como os presos políticos compunham e entoavam músicas que iam desde marchinhas de carnaval a "marchas patrióticas revolucionárias". 8 Mesmo ao levarmos em conta a ilusão biográfica intrinsecamente presente na construção dessas narrativas e a necessidade de reafirmar que a coerência e harmonia reinavam entre os presos políticos, não invalida o fato de que as interações sociais presentes nos relatos sobre o futebol, as festas, o teatro e a música, além da realização dos debates políticos e aulas sobre filosofia, história e economia, nos mostram o quanto a vida social dentro da prisão era viva e rica. Essa intensidade e riqueza de detalhes da vida social prisional exprime que os sujeitos que se encontravam no cárcere conseguiam desenvolver estratégias para aumentar suas margens de liberdade dentro da prisão, apesar da vigilância e apesar de todo o aparato coercitivo montado pelo estado totalitário do regime Vargas, que os levou à prisão. ${ }^{9}$

\footnotetext{
${ }^{7}$ BEZERRA, op. cit., p. 279.

${ }^{8}$ Ibid, p. 277. BARATA, op. cit., p. 312 - 313.

${ }^{9}$ CANCELLI, Elizabeth. O mundo da violência - A polícia da era Vargas. Brasília: ed. UnB, 1994.
} 
O coletivo é sempre referido como o responsável por administrar os bens enviados aos presos pelos familiares, por administrar sua distribuição entre todos e por cuidar da subsistência dos presos políticos menos favorecidos - por vezes, também de seus familiares. Sobre esse assunto, Bezerra afirma que "Éramos uma grande família. Tudo era de todos, principalmente daqueles que mais necessitavam, não só de alimentação como os remédios, vitaminas, etc". Inclusive, ele conta que, em Fernando de Noronha, os presos políticos que adoeciam recebiam reforço na alimentação, como mais leite e mais proteína, para que recuperassem a saúde o mais rápido possível. Mais adiante, o autor também relata que os objetos produzidos por eles na oficina de artesanato que criaram em Ilha Grande eram vendidos e com

“o lucro da seção de vendas e a pequena ajuda dos amigos, suplementávamos as nossas refeições [...]; comprávamos remédios para os que necessitavam, fornecíamos papel, envelope e selos para sua correspondência e ainda fornecíamos à família dos companheiros mais necessitados uma média de 150 a 200 mil-réis por mês, a cada uma delas". ${ }^{10}$

Além da responsabilidade de "cuidar e distribuir equitativamente o que tínhamos (cigarros, doces, café)", bens que em geral eram enviados pelos familiares, era uma incumbência do coletivo "evitar ou desfazer descontentamentos" que pudessem ocorrer entre os presos políticos e os outros sujeitos que compunham com eles a comunidade prisional. ${ }^{11}$ Dessa forma, os autores mostram que apesar de serem "como uma grande família", nas palavras de Bezerra, a convivência diária, durante anos em alguns casos, acabava por desgastar a relação que havia entre eles enquanto coletivo.

Sobre esse assunto, Herondino Pereira Pinto comenta que, em meio ao cotidiano na clausura,

"Surgiam os malentendidos [sic], as brigas, as discussões muitas vezes sem nenhum motivo. Um par de tamancos podia criar uma profunda aversão. Um pedaço de sabão conseguido à custa dos mais ingentes sacrifícios, poderia ser o móvel de uma questão pessoal, que se transformava em querela política.

\footnotetext{
${ }^{10}$ BEZERRA, op. cit., p. 276 e 290.

${ }^{11}$ LIMA, Heitor Ferreira. Caminhos percorridos (memórias de militância). São Paulo: editora Brasiliense, AEL, 1982, p. 167.
} 
Enquanto assim vivíamos, a administração jogava no barracão-presídio alguns presos comuns, para a espionagem. $" 12$

O surgimento de mal-entendidos, brigas e discussões demonstram que, por mais coeso que se mostrasse enquanto coletivo diante da administração prisional, a organização não era completamente impermeável às tensões e conflitos. Antes, funcionava como uma tentativa de evitá-los, buscando conformar o cotidiano prisional de maneira que os presos políticos tivessem uma experiência de clausura o mais parecida possível com a experiência de militância fora da prisão.

Por outro lado, porém, o coletivo buscava desempenhar o papel de criar uma coesão entre os presos políticos que fosse suficiente para mantê-los unidos diante do que considerassem o outro. Assim, em caso de greves, reivindicações de melhorias e reclamações, a organização funcionava como uma estratégia de comunicação formal, mediação e negociação entre eles e o outro que necessariamente não fazia parte do coletivo - a instituição carcerária e os outros presos. Esses momentos em que o coletivo precisava lidar com agentes da administração do presídio ou com os presos por crimes da justiça comum nem sempre ocorriam de forma tranquila e pacífica. Por conta disso, Barata afirma que:

"Como era natural, o Coletivo era odiado pelas administrações dos presídios. Estas não o reconheciam e sempre que podiam (e elas podiam sempre) agrediam com a maior violência aquele organismo que assegurava a nossa coesão e que, assim, reduzia, de muito, os efeitos dos golpes desumanos e terroristas dos selecionados carcereiros da ditadura"13

Como relatou Barata, a interação muitas das vezes era conflituosa e violenta, afinal parte dos agentes da administração são os guardas que detém o poder do uso da força. Diante deles, fazia-se necessário ao coletivo que mantivesse "a unidade entre os presos, impedindo que os carcereiros utilizem a força que possuem para mais oprimir os presos se estes se apresentarem desunidos". ${ }^{14}$

Porém, além do outro presente na imagem dos guardas e funcionários administrativos da prisão, os autores constroem a imagem de um outro. Os presos

\footnotetext{
${ }^{12}$ PINTO, Herondino Pereira. Nos subterrâneos do Estado Novo. Rio de Janeiro: Editora Germinal, 1950, p. 14, p. 62.

${ }^{13}$ BARATA, op. cit., p. 313.

${ }^{14}$ Ibid, p. 310 .
} 
comuns aos quais se referem, que são presos por motivos não políticos ou por crimes da chamada justiça comum, tem uma imagem construída narrativamente bastante singular. Esta, é colocada em um espaço oposto à toda ideia de heroísmo presente na imagem de preso político que os autores constroem para si, afinal percebem-se como homens que dedicaram toda sua vida à causa política e que, mesmo dentro da prisão, não se deixaram abater pela repressão e continuaram organizados. Os autores, enquanto presos por motivos políticos enxergam a si mesmo como heróis nacionais, revolucionários, exemplos de militância e de humanidade. Os homens presos por quaisquer outros motivos são vistos por aqueles como "malandros da pior espécie". Sobre isso, precisamos nos deter um pouco logo adiante.

\section{2. "A promiscuidade com a mais baixa categoria da malandragem"}

Ao relatar a primeira vez em que esteve preso (entre 1917 e 1922) na Casa de Detenção de Recife, Gregório Bezerra descreve o episódio de tentativa de estupro que viveu naqueles tempos, quando tinha apenas 17 anos. Narra que um dia recebeu ordem de mudar para uma cela onde cumpriam pena alguns presos aos quais se refere como pederastas:

“Anísio, Ricardo, Brás e mais uma meia dúzia de presos protegidos da diretoria eram os mandachuvas [sic] do presídio. Davam ricos presentes ao diretor, ao subdiretor e aos funcionários mais categorizados e também a certos guardas e, por isso, desfrutavam de todos os privilégios, enquanto os demais presos, para conseguir o mínimo que fosse da diretoria, tinham que se valer do prestígio dos privilegiados, do contrário não seriam atendidos. "15

Assim que recebeu o aviso sobre a mudança de cela, Bezerra disse para os companheiros da cela em que se encontrava que "preferia morrer a me desmoralizar e que me defenderia até a morte" e para isso se preparou, introduzindo uma faca peixeira na nova cela e escondendo-a atrás do cano de esgoto da privada. "À̀s sete horas da noite, quando terminamos o serviço do rancho dos meninos, fomos recolhidos à cela. Tomei banho, supondo ser o último

${ }^{15}$ BEZERRA, op. cit., p. 167. 
da minha vida. Voltei ao cubículo. Fumei um cigarro e deitei-me. " Depois, conta que

"Ricardo entrou, fez café, ofereceu-me. Não respondi nada. O coração batia. Estava sofrendo um drama dos mais horríveis em minha vida. [...] Ele continuou passeando pela cela. Tomou mais uma xícara de café e fumou mais um cigarro e, supondo-me dormindo, passou a mão no meu peito. Levantei-me bruscamente e dei-lhe um soco com toda força na cara. $\mathrm{O}$ sangue espirrou do nariz e atraquei-me com ele, que escorregou e caiu com a cara em cima da privada. Eu ia tirando a faca que havia escondido atrás do cano de esgoto, quando ele gritou por socorro. Os guardas ouviram os barulhos e os gritos, abriram a grade, entraram na cela e nos separaram. Fui transferido para a cela número oito da mesma galeria. "

Apesar de deslocado na cronologia abordada neste trabalho, o trecho acima retirado das Memórias de Gregório Bezerra é emblemático ao apresentar as noções de honra presentes tanto na sua narrativa quanto na dos outros autores. Para Bezerra, morrer aparece como uma possibilidade mais factível e aceitável do que sofrer assédio nas mãos do preso que qualifica como pederasta. Notemos que o que lhe preocupava não era exatamente a possibilidade de sofrer a violência; sua preocupação tinha raízes na crença de que passar por isso atingiria a sua honra enquanto homem e o desmoralizaria diante de seus pares. Por isso, entre morrer e se desmoralizar, o autor afirma preferir a primeira opção.

Como já dissemos antes, os autores veem na sua experiência de militância e de prisão política uma imagem de heroísmo, pois se pensam como homens que sacrificaram suas vidas pessoais em razão da causa política e que, por isso, sofrem a pena de prisão. Gregório Bezerra inclui-se nisso. Quando narram sobre a experiência no cárcere, esta é descrita como um sofrimento que foi vivido bravamente pois não foi suficiente para abater o preso político, antes acabou por tornar mais fortes as suas convicções políticas e sua militância. Como exemplo disso podemos citar simplesmente os títulos dos capítulos em que Heitor Ferreira Lima e Leôncio Basbaum narram as suas experiências de prisão como parte dos anos de maior intensidade de suas militâncias, Anos duros de combate e Os Tempos Ásperos, respectivamente. Nesta imagem de heroísmo, estão correlacionadas a importância da militância política e a retidão moral, afinal alguém que abdica de suas realizações pessoais em prol de um ideal e padece

${ }^{16}$ Ibid., p. 168. 
sofrimentos por isso automaticamente é visto como alguém que se importa com o mundo e com as pessoas, sendo também e portanto, automaticamente um bom ser humano.

A construção da própria imagem passa pela construção da imagem do outro - por contraposição, como um espelho invertido. Logo, se a imagem que constroem para si mesmos é de heroísmo e retidão moral, os presos políticos se veem como o contrário de um outro, cuja imagem constroem para se contrapor. Nas obras, esse outro aparece principalmente na imagem que tecem dos presos por crimes ditos comuns, mas também quando falam dos presos políticos integralistas e dos guardas da prisão. Dessa forma, há uma pluralidade de outros. Em um movimento subjetivo e dialético, os presos políticos enxergam os outros sujeitos como o seu completo oposto, como seu polo negativo. Por conta disso, os presos por crimes ditos comuns são narrados como sujeitos completamente degenerados, mergulhados na mais completa promiscuidade e baixeza moral.

É dessa forma que está operando, por exemplo, Herondino Pereira Pinto quando reclama sobre o fato de presos políticos estarem no mesmo espaço que os presos comuns:

"isto aqui é mesmo uma covardia. Nós homens trabalhadores, jurídica e socialmente qualificados, estamos assim misturados com ladrões de toda espécie, e malandros de todos os matizes. Agora um 'político' acaba de ser roubado. $" 17$

Ou quando Basbaum afirma que

"aquilo que tínhamos no presídio, era positivamente a escória da humanidade: ladrões tipo pé de chinelo, vagabundos, bêbados, pederastas e até mesmo débeis mentais, como logo descobrimos. "18

Notemos que Pereira Pinto se refere aos presos políticos, categoria na qual estava incluído, como "homens trabalhadores, juridicamente e socialmente qualificados" e os contrapõem aos "ladrões de toda espécie, e malandros de todos os matizes", generalizando todos os outros homens que ali estavam condenados não por motivos políticos como presos de uma categoria inferior, pois seriam ladrões e malandros. A inferioridade seria provada, inclusive, logo na frase

\footnotetext{
${ }^{17}$ PINTO, op. cit., p. 42

${ }^{18}$ BASBAUM, op. cit., p. 134.
} 
seguinte, quando afirma que um "político" acabara de ser roubado. Da mesma forma que um militante não deixava a política ao ser encarcerado, era de se esperar que um ladrão também não deixasse de cometer roubos ao ser posto na prisão pois tais práticas, apesar de completamente diferentes, são entendidas pelos autores como naturais. Basbaum vai mais longe ao enumerar o que eram os presos que ele qualifica como "escória da humanidade", ao equiparar "ladrões, vagabundos, bêbados, pederastas e débeis mentais", como se estas categorias fossem equivalentes.

Se na imagem que constroem para si o heroísmo político e a retidão moral estão correlacionadas como as características intrínsecas que teriam o preso político, no preso comum aparecem correlacionados o fato de ter cometido qualquer crime dito comum, porque julgado em tribunais da justiça comum, e a suposta baixeza moral de sua humanidade. Para o preso político, que tem como motivo de seu encarceramento a prática política injustamente criminalizada, não existe possibilidade de compreender o indivíduo que comete um crime se não pelas suas falhas de caráter, o que demonstra ironicamente que aqueles homens que tinham a política como centro das suas vidas possuíam uma profunda dificuldade de compreender as implicações políticas e sociais relacionadas à criminalidade.

Apresenta-se também na pluralidade de outros uma hierarquia moral. A maior baixeza moral e as piores falhas de caráter eram relacionadas aos presos comuns que apresentavam um comportamento sexual que desvia da normatividade heterossexual. Assim, os homens que praticavam sexo com outros homens dentro da prisão eram sempre referidos como pederastas, vistos como um outro mais inferior que os outros que eram apenas ladrões, assaltantes, assassinos. Por conta dessa associação, a conduta sexual dos presos por crimes ditos comuns dentro da prisão é o incômodo central na imagem construída pelo preso político de seu outro. É significativo que os presos de esquerda demonstrem tanto espanto com as práticas homossexuais, pois denota que, apesar de se reivindicarem como politicamente progressistas, militantes de esquerda, revolucionários, mostram-se extremamente conservadores no que diz respeito à sexualidade que foge à heteronormatividade, algo muito próximo do notado por Lynn Hunt quando 
analisa os revolucionários franceses e a forma estigmatizada como atacavam a moral sexual da corte e da família real. ${ }^{19}$

Caulfield e Schettini, em trabalho que busca mapear como operaram as relações de gênero e sexualidade no Brasil, demonstram que, no regime Vargas de 1930 a 1945, a homossexualidade assim como os direitos dos trabalhadores e das mulheres foram temas de intenso debate. Porém, ao mesmo tempo, a sexualidade continuou a ter um traço extremamente patriarcal e racializada - o que nos dá uma pista para compreender a mentalidade dos autores enquanto presos políticos. As autoras argumentam que Vargas, inspirando-se na interpretação de Gilberto Freyre sobre a miscigenação brasileira, acabou por propagar a noção de "brasilidade" que negava as diferenças raciais e exaltava a honra masculina do trabalhador brasileiro. Para tanto, utilizou a sua própria imagem de maneira paternalista ao referir-se a si mesmo como "pai do povo" e ao representar seu estado corporativista através da metáfora da família patriarcal tradicional enquanto promovia a autoridade masculina da classe trabalhadora em mensagens sobre família e honra nacional. ${ }^{20}$ Dessa forma, podemos compreender que mesmo colocando-se em oposição ao regime Vargas, como homens do seu tempo, os autores haviam internalizado essas noções de honra e autoridade masculinas da classe trabalhadora promovidas pelo governo, mas que tem raízes que operam na sociedade brasileira desde os tempos coloniais e, por isso, levavam a ver de forma negativa a prática de atividades sexuais que fugissem da normatividade heterossexual característica do patriarcado.

Assim, as práticas sexuais entre homens que compunham a parte da população prisional da qual os presos políticos eram incluídos, portanto, são sempre qualificadas por eles como promíscuas, depravadas, vulgares, mas pode ser interessante buscarmos depreender das narrativas dos presos políticos algumas chaves de entendimento utilizadas por eles para explicar o comportamento sexual desviante dos presos comuns.

\footnotetext{
${ }^{19}$ HUNT, Lynn. A pornografia e a Revolução Francesa. Em: HUNT, L. (org.) A invenção da pornografia: obscenidades e origem da modernidade - 1500-1800. São Paulo: Hedra, 1999, p. 329-370.

20 CAULFIELD, Sueann, SCHETTINI, Cristiana. Gender and sexuality in Brazil since Independence. Oxford Research Encyclopedia of Latin American History. Oxford, England: Oxford University Press, Oct 2017.
} 
Ao contar sobre a experiência de prisão em Ilha Grande, Heitor Ferreira Lima afirma que:

"[...] a Colônia Correcional [de Dois Rios] era o presídio mais abjeto que havia, para onde mandavam a escória da malandragem, como os ladrões de todos os tipos: batedores de carteiras, ventanistas, descuidistas, arrombadores, assaltantes e ainda assassinos, pederastas, débeis mentais, valentões de toda espécie, enfim, gente sem o menor sentimento humano nem escrúpulo ou qualquer consideração pelos outros e ainda com trabalhos forçados e sujeitos a constantes surras com vara de marmelo. "21

Se para Basbaum os presos por crimes ditos comuns eram a "escória da humanidade", podemos notar que para Lima eles não se constituíam como algo muito melhor, sendo qualificados como a "escória da malandragem". Porém, da mesma forma que o primeiro, este autor coloca na mesma categoria os indivíduos que se encontram na prisão por terem sido condenados por crimes como assalto e assassinato com "pederastas, débeis mentais, valentões". Significa dizer que, a pederastia ou como era entendida a prática de relações sexuais entre homens, era vista por eles de uma forma criminosa, apesar de não ser um crime desde o Código Criminal de $1830^{22}$. Também a "valentia" aparece aqui, assim como a debilidade mental. A primeira provavelmente se referia a indivíduos que tinham algum papel de liderança dentro da prisão conquistada através do uso da força; a segunda demonstra a maneira preconceituosa e estigmatizada com que as pessoas com deficiências mentais eram vistas.

Podemos entender que os autores compartilhavam a ideia de que o encarceramento por qualquer outro motivo que não fosse político, independente do crime pelo qual o sujeito era condenado, provava que o preso era "gente sem o menor sentimento humano ou escrúpulo ou consideração pelos outros". É dessa forma que os autores julgam moralmente os presos comuns como um grande conjunto de criminosos, como pessoas que só pensam em si mesmos e não respeitam outros seres humanos e a propriedade.

\footnotetext{
${ }^{21}$ LIMA, op. cit., p. 163, 164.

22 A homossexualidade deixou de ser crime com o Código Criminal de 1830, mas homens que praticavam sexo com outros homens, principalmente quando essas práticas tinham lugar em espaços públicos, continuaram a sofrer repressão frequente durante as décadas de 1930 e 1940 e eram enquadrados nos Artigos 282 do Código Penal (ultraje público ao pudor) ou Artigo 399 (vadiagem). Ver: GREEN, James. Além do Carnaval: A homossexualidade masculina no Brasil do século XX. São Paulo: ed. Unesp, 2000, p. 156.
} 
Mais à frente, Lima continua o relato sobre os presos comuns, mas abandona o argumento moralista e passa a relacionar a falta de higiene no cárcere com os roubos de objetos de higiene pessoal que pertenciam aos presos políticos e com a prática da pederastia, deixando claro o horror e repulsa que sentia por conviver com os presos comuns e por escutá-los tendo relações sexuais. Vejamos:

"[...] O mais repulsivo, contudo, era a promiscuidade com a mais baixa categoria da malandragem. Viviam sujos, quase sem banhos, exalando mau cheiro, cuspindo e escarrando em qualquer lugar, roubando tudo que podiam: sabão do nosso uso, escova de dentes, o que nos obrigava a mantê-los continuamente nos bolsos, não possuindo qualquer reconhecimento humano, parecendo mais animais do que gente. A pederastia, muito disseminada, se praticava à noite, debaixo de nossas 'camas', ouvindo-se o ruído, suspiros, gemidos, com homens mais velhos, metidos a valentões, que durante o dia e no trabalho os tratavam com cuidado, conseguindo-lhes café, cigarros, pão com manteiga, defendendoos nas ocasiões de brigas, chamados por isso de 'esteios'. Em sua totalidade provinham dos abrigos de menores, onde se viciaram. Aquela convivência tornava-se chocante, brutal, repugnante mesmo. " 23

Novamente podemos constatar que, apesar da vasta formação política, esta não proporciona consequentemente os meios para o autor compreender a prisão como fruto da sociedade desigual da qual faz parte. Ao invés de tentar compreender a falta de higiene dos presos comuns como parte de um problema estrutural, onde a prisão não se constitui como um espaço que oferece as condições sanitárias necessárias e básicas e que, diferente dos presos políticos que em geral tinham suporte de suas famílias, do PCB e do próprio coletivo, os presos comuns por vezes acabavam abandonados à própria sorte. Além disso, ele apresenta outro tema recorrente quando se trata da prática da pederastia, que é o fato de presos mais velhos e mais fortes forçarem presos mais novos e mais fracos ao ato.

A relação entre presos mais novos com presos mais velhos aparece no relato acima como algo no qual os primeiros se viciaram ainda quando eram menores de idade. É recorrente a referência às práticas de sexo entre homens como vício, assim como dos praticantes como viciados. Por isso, a orientação e identidade sexual dos presos que praticam a pederastia não são uma questão e a

${ }^{23}$ LIMA, op. cit., p. $168,169$. 
explicação dos presos políticos é simples: eles foram forçados a praticar sexo com homens mais velhos e mais fortes e acabaram viciados nisso. A dicotomia entre esses dois tipos de presos é sempre exposta como desigual e desequilibrada: presos mais velhos são sempre qualificados como mais fortes e utilizam a força para aliciar os presos mais novos, que são descritos como mais fracos também. A prática sexual entre esses presos é vista como uma troca de favores, em que sexo é permutado em proteção dentro da prisão.

Madame Satã, figura que ficou muito conhecida como malandro da Lapa naqueles anos e que também esteve preso na Ilha Grande, onde fixou residência ao fim da pena, comenta sobre esses temas em entrevista ao Pasquim. Quando Millôr Fernandes lhe pergunta sobre o que pensa acerca do cantor Osvaldo Nunes, que afirmava que seu "homossexualismo" [sic] foi adquirido na prisão, onde teria sido violentado, Satã diz que isso é

“Conversa fiada, é mentira. É mentira porque na cadeia ninguém faz isso no peito. Tirei 27 anos e oito meses de cadeia e nunca vi ninguém fazer isso no peito. Fazem por livre e espontânea vontade porque querem fazer. Quando eu fui para a cadeia já era pederasta, já era viciado, nunca fiz isso no peito." 24

Ao ser questionado em seguida sobre a prática da homossexualidade ser descrita como um vício, Satã diz que "para uma parte [dos presos que praticam] é" mesmo, mas continua dizendo que isso não acontecia de maneira forçada, que quem praticava o fazia por livre e espontânea vontade em troca de determinadas regalias que outros presos poderiam lhe proporcionar.

"Mesmo no tempo do xerife só se viciava quem queria. O sujeito chegava lá, filho de papai e mamãe, tinha o olho grande, apanhava o cigarro do chefe do alojamento, comia a comida do chefe do alojamento porque queria comer uma comidinha melhor, queria dormir na manta do chefe do alojamento, queria tomar banho com o sabão do chefe do alojamento, ora..." 25

Basbaum nota essa relação de permuta e demonstra que era algo que se propagava pelas gerações de presos:

\footnotetext{
${ }^{24}$ JAGUAR (Org.). As grandes entrevistas do Pasquim. Rio de Janeiro: Editora Codecri, $2^{\mathrm{a}}$ edição, 1976, p. 153.

${ }^{25}$ JAGUAR (org.), op. cit., p. 154.
} 
'Havia também menores presos, rapazolas de 16, 17, 18 anos, os 'pivetes' que, para se defender, buscavam a proteção de ladrões mais velhos e mais fortes, com os quais se 'amigavam'. Eram, então, intocáveis, por uma convenção tácita. Esperavam apenas o tempo suficiente para ficarem mais velhos e mais fortes, para, por sua vez, fazerem o mesmo com outros 'pivetes'. "26

Na citação acima, há também a indicação de que a pederastia não era apenas uma prática pontual, em que os presos incorriam para satisfazer-se. Ao dizer que eles "se amigavam", o autor nos dá a entender que esses presos não apenas praticavam sexo entre si, mas provavelmente viviam algum tipo de relação homoerótica e homoafetiva. Isso não diminui a gravidade que os autores atribuíam ao que viam, ao contrário fazia parte do que classificavam ser um escândalo. Basbaum continua seu relato sobre os presos comuns afirmando que:

"Para mim, aqueles presos eram todos irrecuperáveis, mergulhados na lama abjeta da depravação, até aos cabelos. Para eles somente havia dois mundos, os que conheciam: o dos 'otários', as pessoas que tinham algo que eles queriam e não compreendiam por que lhes fosse proibido tomá-lo; e o deles, o mundo livre da depravação, onde a liberdade não tinha limites. Habituavam-se de tal modo à prisão que muitos deles quase não conheciam outra vida. Para além desse conceito de vida, nada mais existia. Como pode sobreviver uma sociedade que produz tais frutos? Mesmo eu, que já havia convivido com toda espécie de ladrões e marginais, estava chocado. $" 27$

Afirmando veementemente o quanto estava chocado, Basbaum diagnostica que aquela classe de pessoas não conhecia limites para a liberdade e isso os levava a viver na prisão, que qualifica como a "lama abjeta da depravação", o "mundo livre da depravação". E despende uma crítica à sociedade como produtora de indivíduos praticantes de atos tão vis, ao se perguntar "Como pode sobreviver uma sociedade que produz tais frutos?".

As críticas ao comportamento dos presos por crimes ditos comuns são baseadas na degeneração na qual estariam mergulhados e apresentadas para atestar o quanto a prisão não se prestava ao seu papel de corrigir os sujeitos, mas acabava por degenerá-los moralmente ainda mais. Suas críticas se aproximam do discurso policial sobre os presos e criminosos comuns, mas também do que Lila Caimari chamou de saberes criminológicos "profanos", ao mostrar que os debates

\footnotetext{
${ }^{26}$ BASBAUM, op. cit., p. 134.

${ }^{27}$ Ibid, p. 135.
} 
sobre teoria criminológica circulavam pela grande imprensa e provavelmente eram fruto do debate público com um número de publicações crescentes desde o fim do século XIX. ${ }^{28}$ Sendo assim, mesmo que os autores não tivessem formação em criminologia (com exceção de Basbaum que, por ter cursado medicina, deve ter estudado em algum momento um pouco de medicina legal), podemos identificar uma similaridade nos seus discursos com a teoria da delinquência de Enrico Ferri, socialista e discípulo de Lombroso que entendia que a prisão era produtora de criminalidade numa sociedade que apodrece os indivíduos, o que demonstra que essas ideias circulavam na sociedade e permeavam o senso comum.

Por conta da estrutura precária para abrigar os presos e da péssima alimentação que lhes era oferecida mas também por reunir a "mais baixa categoria de malandragem", Pereira Pinto desenvolve uma crítica na qual afirma que "[...] a Casa de Detenção, [era] o maior foco de disseminação de amoralidade, assim como a maior propagadora da delinquência no Brasil" porque "ao invés de corrigir os presos primários e, pelo exemplo, impedir o desenfreamento de taras e vícios, dos que já se abandonaram à completa degenerescência" acabaria por tornar piores as referidas taras e vícios. Nesta crítica está presente ideias criminológicas de forma profana, pois o autor não tinha formação em criminologia, mas entendia a prisão como uma "propagadora da delinquência" que levava os presos "à completa degenerescência".

O autor também relaciona a prática da pederastia com a corrupção dos funcionários da Casa de Detenção do Rio, mostrando que a prática de relações sexuais entre os presos - e novamente com presos menores, que aqui aparecem como indefesos - tinha raízes profundas na dinâmica do cotidiano prisional:

"Vendem-se presos a outros presos em conivência com guardas inescrupulosos, bafejados pela administração da Casa de Detenção, que facilita a prática dos mais vergonhosos atos perpetrados, à força, pelos chefes de cubículos [...] ou então à custa de gorgetas [sic] que são distribuídas entre alguns guardas e seus respectivos chefes.

Realizam-se casamentos homo-sexualistas [sic] apadrinhados pelos chefes de guardas, que, mediante influência de detentos protegidos pela

${ }^{28}$ CAIMARI, Lila. La ley de los profanos: Delito, justicia y cultura en Buenos Aires (18701940). Buenos Aires: Fondo de Cultura Económica, 2007, p. 9.; CAIMARI, Lila. Apenas un delincuente: crimen, castigo y cultura en la Argentina, 1880-1955. Buenos Aires: Siglo XXI, 2004, p. 187 - 194. 
administração e, também, movidos pelo interesse pecuniário, transferem indefesos menores colhidos nas malhas da lei, sob ameaça de serem atirados na cela quando se mostram recalcitrantes, para o 'apartamento' de presos ricos. " 29

Aqui, ao invés de fazer menção discreta ao fato de que havia alguns presos que viviam como casais com a expressão "se amigar", como fez Basbaum, Herondino afirma que na Casa de Detenção eram realizados casamentos entre presos do mesmo sexo. Os casamentos seriam, ironicamente, apadrinhados pela administração. Aqui, o autor critica as autoridades administrativas que seriam corruptas e realizavam cafetinagem de presos menores, reputados pelo autor como indefesos, com os "presos ricos" em troca de "gorgetas" [sic]. Agildo Barata também menciona com horror a prática de pederastia mas também para fazer críticas sobre a corrupção perpetrada pela administração da Casa de Detenção, citando nominalmente o diretor do presídio:

"Este indivíduo foi durante muitos anos, diretor da Casa de Detenção do Rio de Janeiro e membro do Conselho Penitenciário Federal. Para se aquilatar do estofo moral desse pulha apenas um fato: ele recebia percentagens da 'caftinagem' [sic] que se fazia na Casa de Detenção com a pederastia, que grassava entre os presos da justiça comum. O Dr. Aloísio Neiva, recebia percentagens sobre a 'caftinagem' [sic] que se fazia, às escâncaras, com os pederastas na Casa de Detenção que dirigia. "30

Já Ferreira Lima, ainda se referindo às relações entre os presos comuns, não faz nenhuma denúncia de corrupção, mas afirma que "as autoridades presidiárias não só toleravam como até estimulavam tal espécie de relacionamento, buscando com isso evitar descontentamento generalizado, que poderia se tornar perigoso". ${ }^{31}$ Dessa forma, o presídio e sua administração é responsabilizada pelas relações sexuais praticadas entre presos comuns, que são vistas como corrupção.

Portanto, podemos concluir que ao relatar suas experiências na prisão, os autores acabaram por utilizar a noção de coletivo como uma forma de construir narrativamente a imagem heroica do preso político que não deixa de lado nunca a

\footnotetext{
${ }^{29}$ PINTO, op. cit., p. 26, 27

${ }^{30}$ BARATA, op. cit., p. 314.

${ }^{31}$ LIMA, op. cit., p. 169.
} 
sua militância ou a identidade de revolucionário. Antes, a transporta para o cárcere, adaptando as atividades militantes para a prisão política. Por consequência, acabaram por tecer uma imagem dos presos aos quais chamam de comuns, os presos por crimes ditos comuns, como o seu outro, oposto e negativo. Para tanto, utilizaram a sexualidade que consideravam desviante para justificar todos os outros desvios que identificavam no seu outro, relacionando sexualidade e criminalidade, mas também tecendo críticas às prisões e a sociedade brasileira das décadas de 1930 e 1940.

Nossa intenção foi desessencializar as duas categorias, preso político e preso comum, em que a primeira aglomera em seu significa várias conotações políticas, sendo então essencial à uma experiência política e a segunda é completamente esvaziada de qualquer significado político. Apesar de acreditarmos que, em um país profundamente desigual como o Brasil, existem sempre questões políticas no entorno de quase toda prisão efetuada, estamos longe de concordar com a máxima de que todo preso é um preso político - que circulou principalmente entre a esquerda atual desde a prisão do catador de material para reciclagem Rafael Braga no contexto dos protestos de junho de 2013. ${ }^{32}$ Nossa intenção é desfazer essa dimensão essencialmente política na imagem do preso político e essa dimensão essencialmente apolítica do preso comum, mostrando que em nenhuma das categorias essas dimensões se sustentam como absolutas quando lidamos com a experiência social desses homens. A experiência social, portanto, se mostra mais rica, intensa e complexa do que a dualidade essencial.

\footnotetext{
${ }^{32}$ Rafael Braga foi preso por estar com duas garrafas de desinfetante, acusado pelos policiais de estar portando coquetéis molotov. Sua prisão gerou uma campanha entre os ativistas de Direitos Humanos, mas segue preso até hoje.
} 


\section{5}

\section{Conclusão}

A pesquisa que tem nesta dissertação a sua resultância foi fruto de determinadas escolhas. A começar pelas mudanças ocorridas entre o projeto de pesquisa e o percurso de pesquisa. Depois, pela escolha das obras de memórias que compõem o corpus documental e do recorte analítico que foi feito para realizar a leitura dessas fontes. Essas escolhas não foram ao total acaso pois buscavam provar algumas hipóteses e acabaram por determinar a maneira como o trabalho se desenvolveu.

Escolhemos trabalhar cinco obras autobiográficas e, nelas, traçamos um recorte analítico que vislumbra as trajetórias de encarceramento dentro das trajetórias de vida dos autores. Estas fontes têm em comum o fato dos seus autores terem sido presos políticos durante o regime Vargas, o que nos fez tentar compreender como suas narrativas se relacionam com àquele contexto, como também com os seus contextos de escrita, publicação e recepção. Nosso objetivo nesse primeiro momento era apresentar uma análise de caráter mais introdutório às memórias que compõem o corpus documental.

Depois, analisamos as narrativas sobre as trajetórias de encarceramento dos autores, isto é, um recorte dentro das trajetórias de vida que dão a ver as passagens pelas Casas de Detenção do Rio de Janeiro, de Fortaleza e de Recife, mas também suas estadas nas ilhas Grande e Fernando de Noronha e no cárcere em movimento nos quais se constituíram os navios que os transportaram entre prisões continentais e insulares. Os relatos nos permitiram provar a hipótese de que, apesar da situação de coerção e repressão estatal em que se encontravam, os presos conseguiam desenvolver maneiras de negociar e edificar espaços de liberdade e militância. Encontramos isso nas narrativas de uma vida social intensa e permeada de agência em busca da continuidade da militância, apesar da vigilância e dos limites impostos pela prisão e pelo regime ditatorial vivido no país. As relações dos autores, quando presos políticos, com as diferentes autoridades estatais com as quais se chocam ao longo da trajetória de prisão nos 
mostraram diferentes nuances e matizes na maneira de lidar com as negociações necessárias na busca por aumentar as margens de liberdade.

Dentro dos relatos sobre prisão, analisamos também o que dizem os presos políticos sobre si e sobre os presos por crimes ditos comuns. Ao relatarem suas memórias acerca do cotidiano prisional, todos os autores utilizam a noção de coletivo para explicar a organização do cotidiano dos presos políticos. Para eles, essa noção, que possivelmente tinha uma importância fora da prisão, se articula com a militância política, na qual se baseiam todas as características do preso político. Esta, ocupava um papel tão central nas suas vidas, que não era colocada em pausa quando se encontravam na prisão, mas era transformada em elemento definidor da maneira como o cotidiano e o comportamento de um preso político devem se dar no isolamento.

Nestes relatos, diagnosticamos também que há uma construção narrativa que ocorre através de um movimento dialético em que o sujeito ao mesmo tempo que forja sua própria identidade, acabava por idealizar a identidade do outro. Isto é, pudemos perceber que os autores forjaram a identidade de preso político para si, afinal sua prisão se deu por razões políticas, através da noção de coletivo e da estigmatização do chamado preso comum. De forma dialética, acabaram por construir também uma imagem do preso comum como o seu outro, oposto, negativo, inferior - tendo ambas as categorias características quase estáticas. Aqui, provamos nossa segunda hipótese, de que as categorias de preso político e preso comum não são claras e definidas de antemão, mas se constroem na articulação da narrativa e da experiência prisional.

Por fim, como já foi dito nas páginas introdutórias, este trabalho busca se configurar como uma leitura dentre as inúmeras possíveis que podem ser feitas de um corpus documental composto por obras autobiográficas. Longe de se encerrar em si, este trabalho abre inúmeras possibilidades, inclusive através das próprias limitações. Significa dizer que através do corpus documental e do recorte analítico utilizado aqui podemos vislumbrar as determinadas questões que foram trabalhadas e os resultados consequentes. Porém nada impede que estas sejam buscadas em outros relatos sobre as prisões e fontes de outras naturezas, que podem ser manuseadas com o propósito de entender aquelas experiências através 
de outros pontos de vistas ou formas que venham a complementar a compreensão até aqui alcançada. 
Referências bibliográficas

AGUIRRE, Carlos. The Criminals of Lima and their Worlds: The Prison Experience, 1850- 1935. Durham: Duke University Press, 2005.

SAlvatore, R. Crime and Punishment in Latin

America. Durham: Duke University Press, 2001.

Colonies of Settlement or Places of

Banishment and torment? Penal Colonies and Convict Labour in Latin America, c. 1800-1940. In: LICHTENSTEIN, A., DE VITO, C. Global Convict Labour. Leiden, Boston: Brill.

Revisitando el nacimiento de la penitenciaría em America Latina veinte años despues. Em: Revista de Historia de las Prisiones, n. 4, Enero-Junio 2017.

ARTIÈRES, Philippe. Les Livres de Vies Coupables: autobiographies de criminels (1896-1909). Paris, Éditions Albin Michel, 2000.

Arquivar a própria vida. Tradução: Dora Rocha. Rio de Janeiro: Estudos Históricos, 1998.

BEATTIE, Peter M. Punishment in paradise: race, slavery, human rights and a nineteenth-century Brazilian penal colony. Carolina do Norte: Duke University Press, 2015.

BOHOSLAVSKY, Ernesto, DI LISCIA, María Silvia. Introducción: Para desatar algunos nudos (y atar otros). In: BOHOSLAVSKY, Ernesto, DI LISCIA, María Silvia. Instituciones y formas de control social en América Latina, 1840 - 1940 - Una revisión. Buenos Aires: Prometeo Libros: Universidad Nacional de General Sarmiento: Universidad Nacional de La Pampa, 2005.

BOURDIEU, Pierre. A ilusão biográfica. Em: FERREIRA, Marieta de Moraes, AMADO, Janaína (orgs.). Usos e abusos da história oral. Rio de Janeiro: FGV, 1996. 
BRETAS, Marcos, COSTA, Marcos, NETO, Flávio de Sá, MAIA, Clarissa. Introdução: história e historiografia das prisões. Em: BRETAS, M., COSTA, M., MAIA, C.a, NETO, F.S. História das prisões no Brasil. Rio de Janeiro: Rocco, 2009, vol. 1.

Polícia e Polícia Política no Rio de Janeiro dos anos 1920.

Rio de Janeiro: Arquivo e História: Revista do Arquivo Público do Estado do Rio de Janeiro, out. de 1997, n.3.

CAIMARI, Lila. La ley de los profanos: Delito, justicia y cultura en Buenos Aires (1870-1940). Buenos Aires: Fondo de Cultura Económica, 2007.

Apenas un delincuente: crimen, castigo y cultura en la Argentina, 1880-1955. Buenos Aires: Siglo XXI, 2004, p. 187 - 194.

Remembering freedom: life as seen from the prison cell. In: AGuirre, Carlos, SAlvatore, Ricardo. Crime and Punishment in Latin America. Durham: Duke University Press, 2001.

CANCELLI, Elizabeth. O mundo da violência - A polícia da era Vargas. Brasília: ed. UnB, 1994.

Repressão e controle prisional no Brasil: Prisões comparadas. IN: História: questões e debates. Curitiba: Ed. UFPR, n.42, p.141$156,2005$.

CHAZKEL, Amy. Uma perigosíssima lição: A Casa de Detenção do Rio de Janeiro na Primeira República. Em: BRETAS, M., COSTA, M., MAIA, C.a, NETO, F.S.. História das prisões no Brasil. Rio de Janeiro: Rocco, 2009, vol. 2.

CAULFIELD, Sueann, SCHETTINI, Cristiana. Gender and sexuality in Brazil since Independence. Oxford Research Encyclopedia of Latin American History. Oxford, England: Oxford University Press, Oct 2017.

COSTA, Marcos Paulo Pedrosa. Fernando e o mundo - o Presídio de Fernando de Noronha no século XIX. Em: BRETAS, M., COSTA, M., MAIA, C., NETO, F.S. História das prisões no Brasil. Rio de Janeiro: Rocco, 2009, vol. 1. 
Noronha e a reforma prisional no Império. São Paulo: IBCCRIM, 2009.

CYTRYNOWICZ, Roney, MAIO, Marcos Chor. Ação Integralista Brasileira: um movimento fascista no Brasil (1932-1938). Em: DELGADO, L. A. FERREIRA, J. (orgs.). O Brasil Republicano 2. Rio de Janeiro: Civilização Brasileira, 2003. p. $39-61$.

ESTEVA, Diego Pulido. Las Islas Marías: historia de una colonia penal. México: Secretaría de Cultura, Instituto Nacional de Antropología e Historia, 2017.

FILHO, Porfírio de Lima. No tempo dos Látegos e dos Grilhões: memória sobre a Cadeia Pública de Fortaleza (1931). Fortaleza: Arquivo Público do Estado do Ceará, 2013.

GALEANO, Diego Antonio. Criminosos Viajantes - circulações transnacionais entre Rio de Janeiro e Buenos Aires 1890-1930. Rio de Janeiro: Ministério da Justiça e Arquivo Nacional, 2016.

GOMES, Ângela de Castro. Escrita de si, escrita da História: a título de prólogo. In: GOMES, A. C. (Org.). Escrita de si, escrita da História. Rio de Janeiro: FGV, 2004.

GREEN, James. Além do Carnaval: A homossexualidade masculina no Brasil do século XX. São Paulo: ed. Unesp, 2000.

HUNT, Lynn. A pornografia e a Revolução Francesa. Em: HUNT, L. (org.) A invenção da pornografia: obscenidades e origem da modernidade - 15001800. São Paulo: Hedra, 1999, p. 329-370.

JELÍN, Elizabeth. ¿De qué hablamos cuando hablamos de memoria?. In: JELÍN, E. Los trabajos de la memoria. Espanha: Siglo XXI 2001.

LICHTENSTEIN, Alex, DE VITO, Christian. Writing a global history of Convict labour. In: LICHTENSTEIN, A., DE VITO, C. Global Convict Labour. Leiden, Boston: Brill, 2015. 
LINEBAUGH, Peter; REDIKER, Marcus Buford. A hidra de muitas cabeças: marinheiros, escravos, plebeus e a história oculta do Atlântico revolucionário. São Paulo: Companhia das Letras, 2008.

LEVI, Giovanni. Sobre a micro-história. In: Burke, Peter (Org.). A escrita da história: novas perspectivas. São Paulo: Editora da Universidade Estadual Paulista, 1992.

MAGALHÃES, Mário. Marighella, o guerrilheiro que incendiou o mundo. São Paulo: Cia das Letras, 2012.

MAIA, C. A Casa de Detenção do Recife: controle e conflitos (1855-1915). Em: Em: BRETAS, M., COSTA, M., MAIA, C.a, NETO, F.S.. História das prisões no Brasil. Rio de Janeiro: Rocco, 2009, vol. 2.

MARIZ, Silviana Fernandes. Oficina de Satanás: a Cadeia Pública de Fortaleza (1850-1889). Fortleza, 2004. Dissertação de mestrado, UFC.

NASCIMENTO, Grazielle Rodrigues. Fernando de Noronha e os ventos da Guerra Fria - A relação Brasil - Estados Unidos nos anos de JK. Recife, 2009. Dissertação de Mestrado, UFPE.

NETO, Flávio de Sá Cavalcanti de Albuquerque. A reforma prisional no Recife oitocentista: da cadeia à Casa de Detenção (1830-1874). Recife, 2008. Dissertação de Mestrado, UFPE.

Da cadeia à Detenção: reforma prisional no Recife em meados do século XIX. Em: Em: BRETAS, M., COSTA, M., MAIA, C.a, NETO, F.S.. História das prisões no Brasil. Rio de Janeiro: Rocco, 2009, vol. 2.

PANDOLFI, Dulce Chaves. Os anos 1930: as incertezas do regime. Em: FERREIRA, J. e DELGADO, L. (org.). O Brasil Republicano: o tempo do nacional-estatismo - do início da década de 1930 ao apogeu do Estado Novo. Rio de Janeiro: Civilização Brasileira, 2003. 
PEDRETTI, Lucas. Bailes soul, ditadura e violência nos subúrbios cariocas na década de 1970. Rio de Janeiro, 2018. Dissertação (mestrado) - Departamento de História da Pontifícia Universidade Católica do Rio de Janeiro.

RAMOS, Graciliano. Memórias do Cárcere. São Paulo: Martins, 1969.

RODRIGUES, Jaime. Escravos, senhores e vida marítima no Atlântico: Portugal, África e América Portuguesa, c.1760 - c.1875. Almanack, Guarulhos, n. 5, p. 145$177,2013$.

ROMANI, Carlo. Oreste Ristori. Uma aventura anarquista. São Paulo: Annablume, 2002..

ROSE, R.S. Uma das coisas esquecidas: Getúlio Vargas e o controle social no Brasil - 1930-1954. Rio de Janeiro: Companhia das Letras, 2001.

SANT'ANNA, Marilene Antunes. A imaginação do castigo: discursos e práticas sobre a Casa de Correção do Rio de Janeiro. Tese de Doutorado. Rio de Janeiro: UFRJ.

SANTOS, Myrian Sepúlveda. Os Porões da República - a barbárie nas prisões da Ilha Grande: 1894-1945. Rio de Janeiro: Garamond, 2009.

Os Porões da República: a colônia Correcional de Dois Rios entre 1908 e 1930. Em: Topoi, vol.7, n.13, jul.- dez. 2006, pp. 445-476.

SCHWARCZ, Lilia, STARLING, Heloísa. Brasil: uma biografia. São Paulo: Cia das Letras, 2015.

SILVA, Roberta Duarte da. As Alamoas de Fernando: rotinas e vivências das mulheres no presídio de Fernando de Noronha no século XIX (1817-1889). Recife, 2013. Dissertação de mestrado, UFPE.

SEPÚLVEDA, Myrian. Os porões da República: a barbárie nas prisões da Ilha Grande: 1894-1945. Rio de Janeiro: Garamond, 2009. p. 72-91, 156, 182. 
SCOTT, Rebecca J., HÉBRARD, Jean M. Provas de liberdade: uma odisseia atlântica na era da emancipação. Trad. Vera Joscelyne. Campinas: Ed. Unicamp, 2014.

TANNO, Janete Leiko. Cartas de Presos políticos e de seus familiares: violência e atuação feminina no Governo Vargas. 1930-1945. Unesp: Revista Patrimônio e Memória, v. 1, n.1, p. 45-55, 2005. 


\section{Lista de fontes:}

- Fontes autobiográficas:

BARATA, Agildo. Vida de um revolucionário (memórias). São Paulo: Alfa-Ômega, 1978, $2^{\mathrm{a}}$ ed.

BASBAUM, Leôncio. Uma vida em seis tempos (memórias). São Paulo: Alfa-Ômega, $1978,2^{\mathrm{a}}$ ed.

BEZERRA, Gregório. Memórias. São Paulo: Boitempo editorial, 2011.

LIMA, Heitor Ferreira. Caminhos Percorridos (memórias de militância). São Paulo: Brasiliense, AEL, 1982.

PINTO, Herondino Pereira. Nos subterrâneos do Estado Novo. Rio de Janeiro: Germinal, 1950.

- Periódicos consultados - Hemeroteca Digital Brasileira:

A Gazeta, São Paulo, 1914 - 1933.

A Manhã, Rio de Janeiro, 1925 - 1953.

Correio da Manhã, Rio de Janeiro, 1901 - 1974.

Diário Carioca, Rio de Janeiro, 1928 - 1939.

Diário de Pernambuco, Pernambuco, 1825 - 1984.

Diário do Paraná, Paraná, 1945 - 1947.

Diário de Notícias, Rio de Janeiro, 1930 - 1976.

Gazeta de Notícias, Rio de Janeiro, 1875 - 1956.

Jornal do Brasil, Rio de Janeiro, 1891 - 2010.

Jornal do Commercio, Rio de Janeiro, 1829 - 2013. 